Türk Dili Araştırmaları Yılığı-BELLETEN / Yearbook of Turkic Studies BELLETEN

Yıl/Year: 2018, Cilt/Volume: 66, Sayı/Issue: 1 - ISSN: 0564-5050/e-ISSN: 2651-5113 Ankara, TÜRKIYE/TURKEY DOI Numarası/DOI Number: 10.32925/tday.2018.0

\title{
SÜHEYL Ü NEVBAHÂR ÜZERİNE DÜZELTMELER (3)
}

\author{
Sadettin ÖZÇELIK \\ $\ddot{O}_{z e t}$
}

Süheyl ü Nevbahâr üzerine yaptığımız yeni okuma çalışmaları ilerledikçe okunma sorunları ile ilgili düzeltme teklifleri yazmıştı. Bununla ilgili bildiri ve makalelerin künyesi kaynaklarda gösterilmiştir. Çalışmanın sonuna yaklaştıkça tespit ettiğimiz yeni okunma sorunları ile ilgili düzeltme teklifleri ortaya çıktı. Işste bu makalede önceki okuma tekliflerinin devamı olarak yeni okuma teklifleri sunulmaktadır.

Makalede Süheyl ü Nevbahâr'da kelime, tamlama ve birleşik yapıların okunmasında, anlaşılmasında ortaya çıkmış olan birtakım sorunlar üzerinde durulmaktadır. Ayrica Süheyl ü Nevbahâr'dan veya başka eserlerden konuya uygun örnekler sunularak kanitlar sunulmaktadır.

Anahtar Kelimeler: Tarihî metin okumaları, tarihî metinlerde kelime, tamlama ve birleşik yapıların doğru okunması sorunları, Süheyl ü Nevbahâr'dan örnekler.

\section{Corrections on the Süheyl ü Nevbahâr (3)}

\section{Abstract}

As new reading studies on Süheyl ü Nevbahâr progressed, we wrote corrections proposals about the problems of reading. It has been shown in the sources of related papers and articles. As we got closer to the end of the work, we found corrections for new reading problems. This article presents new reading proposals as a continuation of previous reading proposals.

In the article Süheyl ü Nevbahâr focuses on the problems that have arisen in the reading, comprehension and reading of unified structures. Evidence is also presented by offering examples from Süheyl ü Nevbahâr or other works.

Keywords: Historical text reading, the problem of right reading word, word division and word combination, relevant examples from Süheyl ü Nevbahâr.

* Prof. Dr., Dicle Üniversitesi Eğitim Fakültesi Ortaöğretim Sosyal Alanlar Eğitimi Bölümü Türk Dili ve Edebiyatı ABD, sozcelik@dicle.edu.tr, https://orcid.org/0000-0002-7383$\underline{1804}$ 


\section{Düzeltmeler}

Aşağıda Süheyl ü Nevbahâr'ın okunması sırasında ortaya çıkmış olan kelime veya kelimeden büyük dil yapılarının yanlış okunmuş örnekleri üzerinde durulmaktadır. Öncelikle eser üzerinde yapılan okumalarda ortaya çıkmış olan karışıklıklara, sorunlara dikkat çekilmekte daha sonra sorun bağlam ve kurgu kılavuzluğunda çözüm sunulmaktadır. Düzeltmelerin devamında ise varsa eserin kendisinden veya başka eserlerden konuyla ilgili destekleyici kanıtlar verilmektedir. Yeni okuma teklifleri beyit numaraları ve ilgili düzeltme başlıkları altında sunulmaktadır:

178 1. kişiyi iledür $\rightarrow$ kişi èrişür

\section{2. [İşi sol]}

Kişiyi iledür Hālıka hulkdan

[Ki] halk düşmeye halk ile hulk iden (Dilçin, 1991, s. 178)

Yukarıdaki okuma şekli, C. Dilçin'e aittir. Aynı beyti A. Cin, şu şekilde okumuştur:

Kişi iledür hālıka hulkdan

Halk düşmeye halk ile hulk èden (Cin, 2012, s. 14-15)

Yukarıdaki okuma şekilleri incelendiğinde beyitte iki sorun bulunduğu anlaşı1lıyor:

1. İlk dizedeki iledür bağlama uymuyor.

2. İkinci dizenin başındaki halk veya [Ki] halk tamiri bağlama uymuyor.

Kanaatimce Dilçin'in dip notta D nüshasında ilk dizede geçtiğini belirttiği kişi èrişür ile hulkıdan bağlama daha uygun düşer. İkinci dizenin iki nüshada da -aynı satıra göz takılması sonucu olsa gerek- büsbütün yanlış yazılmış olduğu anlaşıllyor. İkinci dizenin baş kısmını burada düş- fiilinin bulunmasından hareketle [İşi sol] düşmeye şeklinde tamir ediyor ve beyti şu şekilde okuyup / tamir edip anlamayı teklif ediyorum:

\begin{tabular}{|l|l|}
\hline $\begin{array}{l}\text { Kişi èrişür Hālıka hulkıdan } \\
\text { [İşi sol] düşmeye halkla hulk èden (178) }\end{array}$ & $\begin{array}{l}\text { İyi huyla kişi Hakka ulaşır. } \\
\text { Kim der ki iyinin işi dolaşır. }\end{array}$ \\
\hline
\end{tabular}

Nitekim şu beyitlerde işi sol düş- ve işi sol ol- deyimleri geçer:

\begin{tabular}{l|l}
\hline İşi sol düşüp düşmiş idi taġa & İşi ters gidip düş̧ı̈ ıssıı dağa. \\
Yèlerdi gehi sola gāhi sag̉a (4067) & Koşup dururdu bir sola bir sağa. \\
Cevāb eyle vėrdidi Nakkāşa ol & Nakkaş’a cevabı şöyle verdi ol. \\
Ki oldı senüy işlerün kamu sol (1452) & Ki senin işlerin hepsi oldu sol.
\end{tabular}


224 tar diril-: sıkıntı içinde yaşamak $\rightarrow$ cimrilik etmek

\begin{tabular}{|l|l|}
\hline Bahil olma vü tar dirilmeyi gör & $\begin{array}{l}\text { Cimri olma ve cimrilik etme sen. } \\
\text { Kim ölicegez saja gij ola gūr (224) }\end{array}$ \\
Ki ölünce mezar olsun sana şen.
\end{tabular}

C. Dilçin, yukarıdaki beyitte dikkat çekilen tar diril- deyimini "zaruret, sıkıntı içinde yaşamak" (Dilçin, 1991, s. 638b) şeklinde anlamıştır. A. Cin ise deyimi, iki ayrı kelime olarak işlemiştir.

Kanaatimce dizenin başındaki bahil olma! 'cimri olma!' dikkate alındığında bu sözün devamında ve denk olarak kullanılmış olan tar diril-(me!) deyiminin anlamı 'cimrilik et-(me!)' anlamında verilmiş bir öğüt olması gerekir. Nitekim ikinci dizede "Ki ölünce mezar olsun sana şen." denilmiş olması da bu düşünceyi destekler. Bu açıklamaya göre söz konusu beyti yukarıda aktarıldığ 1 şekilde anlamak uygundur.

235 yiyil- $\rightarrow$ yèyil-: yenilmek, mağlup olmak

Ādem ag̉usı dili ucındadur

Yiyildügi / yèyildügi bāzūsı gücindedür (235)

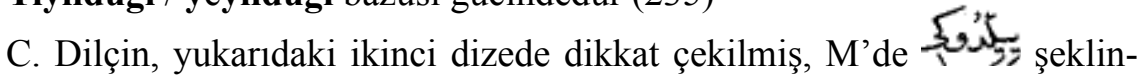
de yazılmış olan fiili yiyil- okumuş ve "çürümek, aşınmak" (Dilçin, 1991, s. 652a) olarak anlamıştır. Dilçin, ayrıca dip notta bu beytin D'de bulunmadığını belirtmiştir. A. Cin ise fiili yeyil- (Cin, 2012, s. 18-12) şeklinde okumuş ve "çürümek, aşınmak; yeyilmek" (Cin, 2012, s. 726b) olarak anlamıştır. Yazım şekline göre fiili, yéyil- okumak uygundur. Ancak verilmiş olan anlamlar bağlama uygun düşmüyor.

Azerbaycan Türkçesi Sözlügü’nde yeyil- fiilinin bir anlamı “...5. Birine yenilmek, mağlup olmak” (Altaylı, 1994, s. 1249b) şeklinde verilmiştir. Bu anlam yukarıdaki beyitte gayet uygun düşer ve söz konusu beyti aşağıdaki şekilde okuyup anlamak mümkündür:

\begin{tabular}{|l|l|}
\hline $\begin{array}{l}\text { Ādem aġusı dili ucındadur } \\
\text { Yèyildügi bāzūsı gücindedür (235) }\end{array}$ & $\begin{array}{l}\text { İnsanın zehiri dil ucundadır. } \\
\text { Yenilgisi bileğin zorundadır. }\end{array}$ \\
\hline
\end{tabular}

Benzer düzeltmeler için bk. 273, 3672, 4297, 4527, 4578 notlar1.

273 yiyil- $\rightarrow$ yèyil-: yenilmek, mağlup olmak

Yiyilüp / yèyilüp yėründen yėle uçmaġ1l

Tuz ètmek hakın yabana saçmaġıl (273)

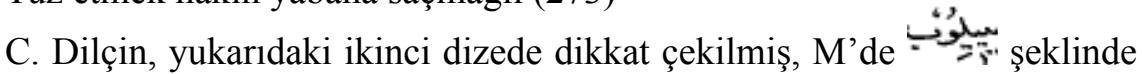
yazılmış olan fiili yiyilüp okumuş ve "çürümek, aşınmak" (Dilçin, 1991, s. 652a) olarak anlamıştır. A. Cin ise fiili yeyil- (Cin, 2012, s. 20-1) şeklinde okumuş ve "çürümek, aşınmak; yeyilmek" (Cin, 2012, s. 726b) olarak anla- 
mıştır. Yazım şekline göre fiili, yèyil- okumak uygundur. Ancak verilmiş olan anlamlar bağlama uygun düşmüyor.

Azerbaycan Türkçesi Sözlügü̈nde yèyil- fiilinin bir anlamı “...5. Birine yenilmek, mağlup olmak" (Altaylı, 1994, s. 1249b) şeklinde verilmiştir. Bu anlam yukarıdaki beyitte gayet uygun düşer ve söz konusu beyti aşağıdaki şekilde okuyup anlamak mümkündür:

\begin{tabular}{|l|l|}
\hline Yėyilüp yėründen yėle uçmag்ı & Yenilip yerinden rüzgâra uçma! \\
Tuz ètmek hakın yabana saçmağı (273) & Tuz ekmek hakkını yabana saçma! \\
\hline
\end{tabular}

Benzer düzeltmeler için bk. 235, 3672, 4297, 4527, 4578 notları.

479, 2219, 2515 temen $(<$ Ar. tev'em) benzer, gibi, sanki

\begin{tabular}{|l|l|}
\hline Anıhtarı alup Süheyl-i Yemen & Yemenli Süheyl anahtar almıştı. \\
Bir ivek işi var sanaydū temen (479) & Sanırsın bir acil işi olmuştu. \\
Çıkubanı atlandı tiz atına & Yoluna koyuldu binip atına. \\
Şolok dem èrişdi kapu katına (480) & Hemen ulaştı kapının katına. \\
\hline Bu yigit ki dèrler Süheyl-i Yemen & Bu yiğit ki adı Süheyl-i Yemen. \\
Anuy sāki bir kulı vardur temen (2219) & Sakisi var sanki bir şarap sunan. \\
Sanasın bir alma durur yarusı & Sanırsın o, bir elmanın yarısı. \\
Sen ü yarusı ol ādem arısı (2220) & Sense o elmanın diğer yarısı. \\
\hline Ya serhoşla ögine düşdi Yemen & Ya aklına Yemen gelmişe benzer. \\
Ya bir genc bulmışa beyzer temen & Ya da bir hazine bulmuşa benzer. \\
(2515) & \\
\hline
\end{tabular}

Araştırmacılar, yukarıda belirtilen üç beyitte, ikinci dizelerin sonunda geçen ve dikkat çekilmiş olan temen kelimesini "Hemen, herhalde, tümüyle, tıpkl" (Dilçin, 1991, s. 639b) ve "Hemen, tümüyle" (Cin, 2012, s. 685a) şeklinde anlamıştır. Tarama Sözlüğ̈̈'nde "Tamamıyla, tıpkl, aynıyla, hemen" (TarS: 3790) anlamları verilmiş ve yalnızca yukarıdaki beyitlerden ikisi tanık olarak gösterilmiştir. Ancak verilen bu anlamlar bağlama uymuyor.

Kanaatimce söz konusu kelime, Arapça 'ikiz, benzer, gibi' anlamları olan tev 'em, tev'eman (Devellioğlu, 1993, s. 1101b) kelimesinin ses değişikliğine uğramış şekli olabilir: tevmen <tev'eman. "tau'amāni (dual of tau'am), Twins." (Steingass, 1930, s. 332b) (= çift ikizler). Söz konusu kelime, Arapçadaki anlamından farklı olarak yukarıdaki beyitte 'benzer, gibi, sanki' anlamında kullanılmış olmalıdır.

479, 2219, 2515 temen ( $<$ Ar. șemen): değerli, pahalı

\begin{tabular}{|c|c|}
\hline $\begin{array}{l}\text { Anıhtarı alup Süheyl-i Yemen } \\
\text { Bir ivek işi var sanayduy temen (479) }\end{array}$ & $\begin{array}{l}\text { Yemenli Süheyl anahtar almıştı. } \\
\text { Acelesi var, hazine bulmuștu. }\end{array}$ \\
\hline $\begin{array}{l}\text { Bu yigit ki dèrler Süheyl-i Yemen } \\
\text { Anun sāki bir kulı vardur temen (2219) }\end{array}$ & $\begin{array}{l}\text { Şu yiğit ki adı Süheyl-i Yemen. } \\
\text { Değerli sakisi var șarap sunan. }\end{array}$ \\
\hline
\end{tabular}


Ya serhoşla ögine düşdi Yemen Ya bir genc bulmışa bejzer temen (2515)
Ya aklına geldi Yemen sarhoştur.

Ya bir değerli hazine bulmuştur.

C. Dilçin, yukarıdaki beyitlerde dikkat çekilen temen kelimesi için " $\mathrm{He}$ men, herhalde, tümüyle, tıpkl" (Dilçin, 1991, s. 639b) anlamlarını vermiştir. A. Cin ise kelimeyi "Hemen, tümüyle" (Cin, 2012, s. 685a) şeklinde anlamıştır. Ancak bu anlamlar bağlama uymaz.

Yalnızca yukarıdaki üç beyitte geçen söz konusu kelime, Arapça șemen olup, 'değer, paha' vb. anlamlarda kullanılır. Metindeki şeklinden kelime başında ünsüz değişikliği olduğu anlaşılmaktadır: temen ( $<$ Ar. șemen). Kelimenin Arapçada, 'değer, paha' anlamında olmasına karşılık metnin bağlamın göre yukarıdaki beyitte 'değerli, pahalı' anlamlarında kullanılmış olduğu anlaş11ıor.

566 atası $\rightarrow$ anas 1

Alurdı atası dizine başın

Silerdi yẻniyile gözi yaşın (566)

Araştırmacılar yukarıdaki beyitte dikkat çekilmiş olan kelimeyi atası şeklinde okumuştur (Dilçin, 1991, s. 566: Cin, 2012, s. 39-11).

Söz konusu kelime M nüshasında 'كَّ şeklinde yazılmıştır. Dilçin'in dip notundan kelimenin D nüshasında da aynı şekilde yazılmış olduğu anlaşılmaktadır. Ancak bağlama göre x nüshasında müstensihin bu kelimede nun yerine te yazmış olduğu kesindir. Çünkü bağlama göre metinde anası yerine atası yazılmış olması gerekiyor. Nitekim -aşağıda da görüldüğü gibi- bunun hemen iki beyit sonrasında (568) geçen Dédi şāha bir gün ki şefkat kanı? ve 571. beyitteki Bunı dèdi vü ag̀ladı ol nigār / Şehün eyledi yüregini figār sözlerinden de burada anası bulunması gerektiği açıkça anlaşılıyor:

\begin{tabular}{|l|l|}
\hline Og̉ul dėyü dökerdi gözden kanı & Oğul, diye akıtırdı gözden kan. \\
Atar idi oda bulursa canı (567) & Atar idi ateşe bulsaydı can. \\
Dėdi şāha bir gün ki şefkat kanı? & Anası der: Ey şah, şefkatin hani? \\
Görürsin bu hāletde uş oğlanı & Görüyorsun oğlunun sen hâlini. \\
Ki ne yèr ta‘ām u ne dèr ş̧idür & Ki ne yemek yer ve ne der, işitir. \\
Ne bilür geleni ki ne kişiür (569) & Hem de ne tanır gelen ne kişidir. \\
Düriş ola kim bulasın çāre sen & Çalış ki umulur bulursun çare. \\
Cihān için armayuban ara sen & Bu dünyayı yorulmadan sen ara! \\
Ve ger ni işüm ana èrdi i şāh & Ey şah dediğimi yapmaz isen sen. \\
Ki nāgāh èdem kendüzümi tebāh (571) & Bil ki birgün kıyarım canıma ben. \\
Bunı dėdi vü aġladı ol nigār & O sevgili bunu dedi, ağladı \\
Şehüy eyledi yüregini figār & Şahın yüreğini birden dağladı. \\
\hline
\end{tabular}

Buna göre söz konusu beyit, şu şekilde okunup anlaşılmalıdır: 


\begin{tabular}{|l|l|}
\hline Alurdı anası dizine başın & Anası dizine alırdı başın. \\
Silerdi yėniyile gözi yaşın (566) & Yeniyle silerdi onun gözyaşın. \\
\hline
\end{tabular}

739 ur yüregüme $\rightarrow$ urma yürege

Ki ey gözlerümün çerāğ og்ul

Yèter ur yüregüme tag்1 og̉ul (739)

Araştırmacılar, yukarıdaki beyitte dikkat çekilmiş olan kısmı metindeki yazım şekline uygun olarak ur yüregüme okumuşlardır (Dilçin, 1991, s. 739; Cin, 2012, s. 51-5). Ancak bu okuma şekli anlam vermiyor.

Kanaatimce ikinci dizedeki ur yüregüme ibaresi, urma yürege şeklinde düzeltilerek okunduğunda beyitte bağlama uygun anlam sağlanmış oluyor. Yani beytin şu şekilde okunup anlaşılması mümkündür:

\begin{tabular}{|l|l|}
\hline Ki ey gözlerümün çerāġı og̉ul & Ey benim gözlerimin nuru oğul! \\
Yèter urma yürege tağı og்ul (739) & Yeter çek yüreğimden dağı doğrul. \\
\hline
\end{tabular}

823 giriş-: dostluk kurmak, yakınlaşmak

\begin{tabular}{|l|l}
\hline $\begin{array}{l}\text { Kamu pādişāhlar ile èrişe } \\
\text { Ola dost her birine girişe (823) }\end{array}$ & $\begin{array}{l}\text { Şahlara ulaşıp dost olmak ister. } \\
\text { Onlarla tanışıp görüşmek ister. }\end{array}$ \\
\hline
\end{tabular}

Araştırmacılar, yukarıdaki beytin sonunda geçen giriş- fiilini "birbiri içine girmek, karışmak" (Dilçin, 1991, s. 608a) ve "içiçe girmek, karışmak" (Cin, 2012, s. 530a) şeklinde anlamıştır. Ancak bu anlam bağlama uygun düşmüyor.

Bağlama göre söz konusu fiilin ‘dostluk kurmak, yakınlaşmak’ anlamında kullanılmış olduğu anlaşılıyor.

1043 1. degirmidük $\rightarrow$ degir miydük (deg-ir 'değ-er, uygun düş-er')

2. kulları çün $\rightarrow$ kullarıçun ( $<$ kulları için)

\begin{tabular}{|l|l|}
\hline Degir miydük ạa ki şāh ạsuzın & $\begin{array}{l}\text { Değer miydik ona ki şah ansızın. } \\
\text { Üşendüre kullarıçun kendüzin (1043) }\end{array}$ \\
Yorsun kulları için o, kendisin.
\end{tabular}

1. C. Dilçin yukarıdaki beytin başında geçen fiili, metindeki yazılışına uygun olarak degirmidük şeklinde okumuştur (Dilçin, 1991, s. 1043). A. Cin de aynı okuma şeklini benimsemiştir (Cin, 2012, s. 70-7). İ. Taş ise söz konusu fiili ET'deki tegür- 'eriştir-, ulaştır-' ile ilişkilendirmek istemiş ve "...Bu durumda SN'deki degir- biçimini düzleşme ile açıklayabiliriz: degir- < degür- < tegür- <teg-ür-." (Taş, 2015, s. 41) demiştir.

Kanaatimce söz konusu fiilin dük okunması ve 'değer miydik' şeklinde anlaşılması gerekiyor. Burada yapısal olarak deg- fiilinin geniş zaman çekiminde kullanılmış olmalıdır. Ancak fiilin kullanılışında bir ağız özelliğinin yazıya yansımış / geçmiş olduğu anlaşıl1yor. Bu ağız özelliği nedeniyle de fiil, metinde deger miydük değil degir 
miydük okunacak şekilde yazılmıştır. Benzer kullanılış şeklinin geçtiği aşağıdaki beyitte fiilin degir miydüm okunacak şekilde yazılmış olması da bu düşünceyi destekler:

Konugun kodun 'işi terk eyledüy

Degir miydüm ana beni sayladuy (2214)
Toyundan geçtin ve konuktan geçtin.

Değer miydim ona; sen, beni seçtin?

Yukarıdaki beyitte konuşan Nevbahârdır. Yani Nevbahâr, yukarıdaki sözleri konuklarını bırakıp kendisini görmeye gelen babasına söylemiştir. Geniş açıklama için beyit hakkında yazılmış olan nota bakılabilir.

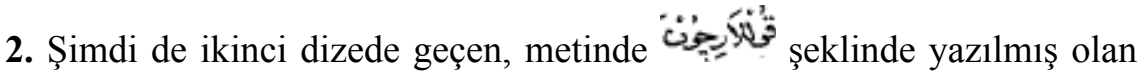
kelimeler üzerinde duralım. C. Dilçin ve A. Cin, kelimeleri kulları çün (Dilçin, 1991, s. 1043; Cin, 2012, s. 70-7) şeklinde okumuşlardır. A. Cin burada çün okuduğu kelimeyi “çün: (Far.) Çünkü, ne zaman" (Cin, 2012, s. 485a) başlığ1 altında işlemiştir. Sözlüğe almamış olsa da Dilçin'in okuyuşundan kelimeyi benzer şekilde anladığı açıktır. Ancak bu okuma şekli ve anlam, bağlama uymaz.

Kanaatimce ikinci dizede çün değil içün kelimesi bulunuyor ve vezin gereği kelimede zihaf yapılmıştır. Yazım şekli ve zihaf konusu dikkate alındığında

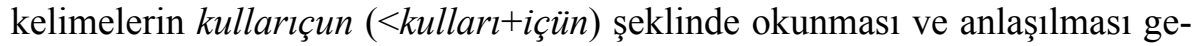
rektiği anlaşılıyor. Bu açıklamalara göre söz konusu beyit yukarıda gösterildiği şekilde anlaşılabilir.

Okuma şekli ve sözü edilen anlamı şu beyitlerde geçen ve aynı anlamda kullanılmış olan fiilin üç örneği de destekler:

\begin{tabular}{|l|l|}
\hline Baya şol degir kim diyem bildügüm & Bana şu düşer ki diyem bildiğim. \\
Anıllığıla tez şeşilür düğüm (1197) & Sükunetle tez çözülür her düğüm. \\
Dedi yüzüm açmah degir mi sạa & Dedi: Yüzüm açmak düşer mi sana. \\
Edebsüz sözi söylemegil baya (3103) & Saygısızca sözler söyleme bana. \\
Eyitdi bu 'ālem degir mi aya & Dedi: Bu dünya değer mi hiç ona. \\
Ki ‘ākil nazar ede andın yạa (4577) & Akıllı kişi, baksın ondan yana. \\
\hline
\end{tabular}

1172 yègrek $\rightarrow$ yėgerek

Ki sizsiz baya atadan yégerek Sizüy hükmünüz nise tutmak gerek (1172)
Ki babadan bana iyi sizsiniz.

Neyse yapmak gerekir, kararınız.

Yukarıdaki ilk dizenin sonunda geçen ve metinde يُكَّك şeklinde yazılmış olan kelime, araştırmacılar tarafindan yigrek (Dilçin, 1991, s. 1172) ve yègrek (Cin, 2012, s. 78-9) okunmuştur. Kelimenin metindeki yazım ve okunma şekine göre vezin eksik kalmaktadır. Kanaatimce vezni sağlamak için Mesud'un sıklıkla başvurduğu vezin ve kafiye tasarrufu örnekleri ve alt dizenin sonun- 
daki gerek kelimesi dikkate alındığında yėgrek'i yėgerek şeklinde okumak yeterli ve uygun olacaktır.

1465 boyun tart- $\rightarrow$ boyun tut-: boyun eğmek

\begin{tabular}{|l|l}
\hline Gönül kapucı eyle oynar oyın & Gönül alıcı öyle oynar oyun.
\end{tabular}

$\mathrm{Ki}$ baş koşduğun bilse tutar boyun Baş koyduğunu bilse eğer boyun (1465)

C. Dilçin, yukarıdaki beyitte dikkat çekilmiş ve metinde şseklinde yazılmış olan deyimi M nüshasındaki yazılışına uygun olarak boyun tart- şeklinde okumuş ve "kendini geri çekmek, nazlanmak" (Dilçin, 1991, s. 594b) olarak anlamış, dipnotta D nüshasında dutar okunacak şekilde yazılmış olduğunu belirtmiştir. M nüshasını çalışmış olan A. Cin de deyimi aynı şekilde okumayı tercih etmiş ve deyime "kendini geri çekmek" (Cin, 2012, s. 467b) anlamını vermiştir.

Kanaatimce bağlam, deyimin D nüshasında geçen boyun dut- şeklindeki yazımın doğru olduğunu ve 'boyun eğmek' anlamında kullanıldığını gösteriyor. Nitekim ayn deyim metinde boyun dut- (3046) ve boyun tut- (1042, 3924) okunacak şekilde yazılmıştır. Yukarıdaki beyitte M yazıcısının vav yerine re yazmış olduğu anlaşıliyor.

Ayrıca söz konusu deyim, Süheyl ü Nevbahâr'da boyun uzat- $(444,2759)$ ve boyun vèr- $(1593,1998)$ şeklinde de geçer.

1466 yarın $\rightarrow$ yārin: yârini, sevgilisini

\begin{tabular}{|l|l|}
\hline Gèrü göresin yarın ol nicesi & $\begin{array}{l}\text { Bak yarın o yine nasıl gelecek. } \\
\text { Gele yārin isteyü ol nicesi }\end{array}$ \\
Yârini orda nasıl bekleyecek.
\end{tabular}

C. Dilçin, yukarıdaki beytin ikinci dizesinde dikkat çekilmiş olan kelimeyi yarın 'yarınki gün' şeklinde okumuş ve anlamıştır. A. Cin, kelimeyi aynı şekilde okumuş (Cin, 2012, s. 97-15) ve sözlükte "Ahiret, yarın" (Cin, 2012, s. 718a) anlamını vermiştir. Ancak bu okuma şekli ve anlamlar metne uygun düşmüyor.

Bağlam ve yazım şekline göre kelimeyi yârin okunup 'yâr+ini, sevgili+sini' şeklinde anlamak gerekiyor. Bu beyitte Nakkaş, Süheyl'e merak etmemesi gerektiğini ve ertesi gün Nevbahâr'in yine kendisini görmeye geleceğini söylüyor.

1517 düş- $\rightarrow$ duş-: rastlamak

Hayāline düşüp oldundı ey Süheyl hayāl

Gel indi uş yüzini gördüy oldı hoş sana hāl 
Araştırmacılar, yukarıdaki beytin sonunda geçen fiili düşüp 'düşmek' şeklinde okuyup anlamıştır (Dilçin, 1991, s. 1517; Cin, 2012, s. 187-1, 504b). Ancak bu okuma şekli ve anlam bağlama uymaz. Söz konusu fiilin duşup $(<d u s ̧$-up) okunup 'rastlayıp' şeklinde anlaşılması gerekir. Bağlama göre beytin şu şekilde okunup anlaşılması uygundur:

\begin{tabular}{|l|l|}
\hline $\begin{array}{l}\text { Hayāline duşup oldundı ey Süheyl hayāl } \\
\text { Gel indi uş yüzini gördüy oldı hoş saya } \\
\text { hāl (1517) }\end{array}$ & $\begin{array}{l}\text { Sühyl, düşe rastlayıp oldun hayâl! } \\
\text { Yüzün gördün, oldu sana bir hoş hâl. }\end{array}$ \\
\hline
\end{tabular}

Benzer düzeltmeler için bk. 2818, 3611, 3748, 5440 notları.

\section{3 bilik $\rightarrow$ bölük}

\begin{tabular}{|l|l|}
\hline $\begin{array}{l}\text { Saçı biligin tā kim atdı kemend } \\
\text { Bırahdı bu boynuma bin dürlü bend } \\
(1583)\end{array}$ & $\begin{array}{l}\text { Saç bölüğü ile attı o kement. } \\
\text { Boynuma binlerce düğümledi bent. }\end{array}$
\end{tabular}

Yukarıdaki beyitte dikkat çekilen kelime, metinde biligin okunacak şekilde yazılmıştır. Araştırmacılar bunu biligin (Dilçin, 1991, s. 1583) ve bèligin şeklinde (Cin, 2012, s. 105-5) okumuştur.

Ayn1 kelime 1484, 1485, 1487, 1558, 1654, 1748, 1778, 1970. beyitlerde hep bölük okunacak şekilde yazılmış olduğuna göre bunun bir yazım yanlışı olduğu anlaşıliyor.

1616 ola $\rightarrow$ ula! 'yapış, yaklaş!'

\begin{tabular}{|l|l|}
\hline Hemin baya meşg்ūl ol her sözüy & Hep benimle olsun her sözün. \\
Ki ula baya söylegil kendüzüy (1616) & Öyle ki sen yaklaştır bana özün. \\
Tama bahma kaldurma aslā başuy & Dama bakma, asla kaldırma başın! \\
Kurıtma bilüni akıtma yaşun (1617) & Aklını kaybedip akıtma yaşın! \\
\hline
\end{tabular}

Araştırmacılar, yukarıdaki ilk beyitte dikkat çekilen ilk kelimeyi ola şeklinde okumuştur (Dilçin, 1991, s. 1616; Cin, 2012, s. 107-2). Bu okuma şekli beyitte anlam vermiyor.

Kelimenin ula! şeklinde okunup 'yapış, yaklaş!' olarak anlaşılması bağlama gayet uygun düşer. Bunun için bir özet yapmak gerekiyor. Nakkaş yukarıdaki beyitlerde Süheyl ile konuşmakta ve Nevbahâr dama çıktığında nasıl davranması gerektiği konusunda Süheyl'e fikir vermektedir. Nakkaş, Süheyl'in hep kendisiyle sohbet etmesi gerektiğini ve adeta kendisine yapışması gerektiğini; asla başını yukarı kaldırıp Nevbahâr'a bakmaması gerektiğini sıkı sıkıya öğütlüyor. Bu durumda söz konusu beyitler yukarıda gösterildiği şekilde anlaşı1labilir.

Söz konusu beyitteki kendüzin ula- deyimi, Atabetü'l-Hakâyik'te de geçer. Edip Ahmet Yüknekî, okuyucuya seslenirken söz konusu deyimi, bilgili ile dost olmak konusunda özüyni ula! şeklinde kullanır: 


\begin{tabular}{|l|l|}
\hline Biligdin urur men sözümke ula & Bilgiden sözüme temel atarım; \\
Biliglikke ya dost özüyni ula! & Ey dost, bilgiliye yaklaşmağa çalış \\
(Arat, 1992, s. 47) & (Arat, 1992, s. 85) \\
\hline
\end{tabular}

1742 göre $\rightarrow$ gör e! 'bak a!'

Cevāb eyle vèrdi yüzini göre

Berü ag̀ ne söz vaķtidür ey sere

Araştırmacılar, yukarıdaki beyti metindeki yazım şekline uygun olarak okumuşlardır (Dilçin, 1991, s. 1742; Cin, 2012, s. 115-6). Ancak bu okuma şekli anlam vermiyor.

Kanaatimce ilk dizenin sonundaki doğru okuma göre değil, gör e! şeklinde olmalıdır. Buradaki gör e! 'bak a!' anlamında olup beyitteki iki dize de pekiştirme edatı ile sonlanmıştır. Yani beyit aşağıdaki şekilde okunup anlaşılabilir:

\begin{tabular}{|l|l|}
\hline Cevāb eyle vèrdi yüzini gör e! & Şöyle cevap verip dedi hey bir bak! \\
Berü ag ne söz vaktidür ey sere! (1742) & Beri çı söz vakti değil, ey ahmak! \\
\hline
\end{tabular}

1834 diri kurtıla 'diri kurtulur mu?' istifham

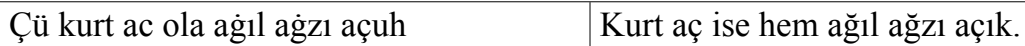

Diri kurtıla kuzı yaru buçuh (1834) $\quad$ Kuzu diri kurtulur mu az buçuk.

Yukarıdaki beyitte bağlama göre vurgu ve tonlama yoluyla bir istifham yapılmış olduğu anlaşılıyor. Beyit, yukarıda gösterildiği şekilde anlaşılabilir. Benzer örnekler için bk. 4029, 3158 notları.

2002 olur $\rightarrow$ yèr ol-: 1. toprak olmak, 2. yemek (tevriye)

\begin{tabular}{|l|l|}
\hline Dürişse kişi kayġusin yėr olur & Kişi çabalarsa kaygısın yener. \\
Yėri yār içün yaruban yėr olur (2002) & Yâr için yer yarıp kendi olur yer.
\end{tabular}

Kanaatimce yukarıdaki beyitte yèr ol- deyimi 'toprak olmak' ve '(toprağı) yemek' anlamları ile kullanılmış olduğundan bir tevriye yapılmıştır. Aynı zamanda iki dizede kurulmuş olan kafiye bir cinas örneğidir.

2127 karaġu 'kör' $\rightarrow$ 'görme zaafi'

Piyāle dahı sākinüy enegi
Göyül bigi sādeyise oldur yejgi (2126)
Eger ola dak riş ü yā karag̀u
Olur āb-1 hayvān elinden ag̉u (2127)

Şarap kadehi ve sâkî çenesi, Gönül gibi sadeyse en iyisi Kel, yaralı, kusurlu olsa gözü Elinden can suyu, zehir ve sızı

C. Dilçin yukarıdaki 2127. beyitte geçen karaġu için "kör" (Dilçin, 1991, s. 618) anlamını vermiştir. S. Tezcan, Dilçin' in bu açıklamasını doğru bulduğunu belirtmiş ve şöyle demiştir:

Dilçin, buradaki karag்'yu (s. 618'de), Karahanlıca karag் 'kör' ile birleştirmekte haklıdır. Ancak kelime DerS.'nde (2644) yalnız iki yerden derlenmiş olan kară̆l 'güneş battıktan sonra göz görmeme hastalığı, tavukkarası' dışında 
Anadolu Türkçesinde galiba yok (TarS.'nde yok). Sanırım, SN'da 'kör' değil, (herhalde insan yüzüne iğrenç bir görünüm veren) bir göz hastalığının adı olarak anlaşılmalı (Tezcan, 1994, s. 28).

Söz konusu kelime İshak bin Murad'ın Edviye-i Müfrede adlı tıp metninde "Zeyt, yenisi mutedildür ve eskisi issidür; göze çekseler göz karaguligın giderür." (Canpolat, Önler 2007, s. 19a.9) cümlesinde karagulık şeklinde -bir yerde de olsa- tespit edilmiştir. Bu tıp metninin çalışıldığ 1 kitapta karagulık, 'körlük' olarak tanımlanmış ve tanık olarak yukarıdaki cümle eklenmiştir (Canpolat, Önler 2007, s. 149). Ancak kanaatimce Edviye-i Müfrede'nin yazıldığı dönemde körlüğe bir tedavi veya ilaç bulunmuş olduğu düşünülemez. Nitekim verilen tanık cümleden anlaşıldığına göre tıp metninde karagulık 'görme zaafı' anlamında kullanılmış olmalıdır. Buna göre Süheyl ü Nevbahâr'da geçen yukarıdaki beyitte geçen karagu kelimesi de 'görme zafı olan kimse' anlamında kullanılmış olmalıdır.

\section{1. uturu uturu, oturu oturu $\rightarrow$ ötürü ötürü (<öt-ür-ü)}

2. degirü $\rightarrow$ dikerü $(<\operatorname{dik}+$ erü)

\begin{tabular}{|l|l|}
\hline Hemān lahza şāh uturu uturu & $\begin{array}{l}\text { Hemencecik baba şah kese kese. } \\
\text { Becid bahdı birkaç kıza dikerü (2165) }\end{array}$ \\
Dikkatlice baktı birkaç kez kıza
\end{tabular}

1. C. Dilçin, yukarıdaki beytin ilk dizesinde dikkat çekilmiş ve metinde

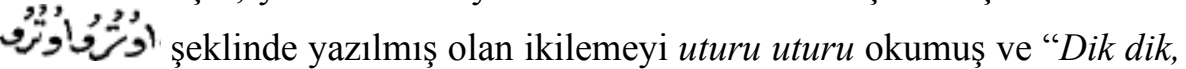
dikkatlice" olarak anlam vermiştir (Dilçin, 1991, s. 644).

S. Tezcan, yazdığı notta önce ötürü ötürü bah- 'keskin keskin, delici bakışlarla bakmak' okuyup anlamanın mümkün olabileceğini söylemiş daha sonra bu düşüncesinden vazgeçerek "Ne var ki Anadolu Türkçesinde öt-, ötür- böyle bir anlama gelmiyor. Bu yüzden belki daha basit bir çözüm olarak oturu oturu 'oturarak'okumak tercih edilmeli' (Tezcan, 1994, s. 28) demiştir. A. Cin, herhalde Tezcan'ın bu görüşünü dikkate alarak, ikilemeyi oturu oturu okumuş ve “oturarak" (Cin, 2012, s. 143-7) şeklinde anlamıştır.

Kanaatimce fiil için yapılan tahminlerden bağlama uygun olanı Tezcan'ın ilk düşünmüş olduğu ötürü ötürü bah- 'keskin, delici bakışlarla bakmak' şeklindeki anlamdır. Nitekim Türkiye Türkçesinde kesişmek fiili, argo olarak " $i k i$ kişi birbirlerine duydukları ilgiyi belli edecek biçimde bakışmak” (Aktunç, 2000, s. 178a) anlamında kullanılır. Ayrıca kes- fiili “24. mec. Karşı cinsten birisini sürekli olarak süzmek, dikkatli bir biçimde bakmak” (Türkçe Sözlük, 2011, s. 1400b) anlamında kullanılır. Fiilin günümüzde kullanıldığg bu anlamlar da ötürü ötürü bah- 'keskin, delici bakışlarla bakmak; incelemek' şeklindeki bir anlamı destekliyor. 
2. C. Dilçin, yukarıdaki beytin ikinci dizesinde dikkat çekilmiş ve metinde ديِِّ şeklinde yazılmış olan fiili, degirü okumuş ve "Dokundurmak" (Dilçin, 1991, s. 599) olarak anlamıştır.

A. Cin, fiili aynı şekilde okumuş ve "bildirmek, dokundurmak" (Cin, 2012, s. 143-7, 490) olarak anlamıştır. S. Tezcan, Türkmence dikger- 'başını yukarı kaldırmak, başını dik tutmak' fiiliyle karşılaştırıp bunu dikgerü okumayı teklif etmiştir (Tezcan, 1994, s. 28-29). İ. Taş ise fiili, "ET tegür- 'erişstirmek, ulaştırmak' eyleminden getirmek daha doğrudur" demiştir (Taş, 2015, s. 41).

Kanaatimce bu teklifler metni aydınlatmaktan uzaktır. Söz konusu kelimenin yapısı, kafiye ve vezin tasarrufu ile açıklanabilir. Çünkü burada dik dik bak- veya gözünü dikerek bakmak söz konusudur. Ancak manzum olan eserde kafiye ve vezin endişesini göz ardı etmek mümkün değildir. Bu nedenle beyitte hem ilk dizedenin sonundaki ötürü ile kafiye kurmak hem de vezni sağlamak amacıyla dik (dik) bak- yerine dikerü ( $<$ dik+erü $<$ dik+gerü) bakmak kullanılmış olduğunu düşünüyorum. Nitekim Tezcan'ın konu ile ilgili olarak Türkmenceden vermiş olduğu tanık da bu görüşü destekler.

2173 getür- $\rightarrow$ güç götür-

Bilüben hele dek oturmayavuz
Gücümüz yèter güç götürmeyevüz
(2173)

Bunu bilip sakin oturamayı.

Gücümüz yetiyor katlanamayı.

C. Dilçin, yukarıdaki beytin ikinci dizesinde dikkat çekilmiş olan fiili, yazılışına uygun olarak güç getür- şeklinde okumuş, ancak sözlükte işlememiştir. A. Cin de aynı okuyuşu benimsemiş (Cin, 2012, s. 143-15) ve fiili sözlükte iki ayrı kelime olarak işlemiştir (Cin, 2012, s. 529a, 541b). Ancak bu okuma şekli ve anlam, bağlama uymuyor.

Bu beyitte geçen fiil, güç götür- 'sıkıntıya, zülme katlanmak' olmalıdır. Metinde götür- filininin ilk hecesinde bir hareke yanlışı yapılmış, ötre yerine üstün yazılmıştır. Nitekim güç götür- deyimi şu beyitlerde de geçer:

\begin{tabular}{|c|c|}
\hline $\begin{array}{l}\text { Sözüy tatlu olup götürsen güci } \\
\text { Senüy dirligüy olmaya hiç acı (236) }\end{array}$ & $\begin{array}{l}\text { Katlansan tatlı sözle sen acıya. } \\
\text { Hayatında düşmezsin hiç acıya. }\end{array}$ \\
\hline $\begin{array}{l}\text { Baya ne yaraşurdı içmek süci } \\
\text { Veli sımadum söz götürdüm güci (1200) }\end{array}$ & $\begin{array}{l}\text { Bana yakıştı mı şu içmek şarap! } \\
\text { Söz kırmayıp buna katlandım ya Rab! }\end{array}$ \\
\hline $\begin{array}{l}\text { Kişinüy ne var '1şk üzerse gücin } \\
\text { Olur olmazuy çoh götürür gücin (1988) }\end{array}$ & $\begin{array}{l}\text { Şaşılır mı aşk şu gücü tüketir, } \\
\text { Olur olmaz sıkıntıyı taşıtır. }\end{array}$ \\
\hline $\begin{array}{l}\text { Atadan götürmezse og̉ul güci } \\
\text { Peşimān ola işine soy ucı (3013) }\end{array}$ & $\begin{array}{l}\text { Baba sözü oğula gelse acı. } \\
\text { Oğlu, yine pişman olur son ucu. }\end{array}$ \\
\hline $\begin{array}{l}\text { Bilüy kim gözedü duran iş ucın } \\
\text { Gerek kim götüre niçenüy gücin (5385) }\end{array}$ & $\begin{array}{l}\text { Bilin işin sonuncunu düşünen. } \\
\text { Olmalı çok sıkıntıya katlanan. }\end{array}$ \\
\hline
\end{tabular}


Söz konusu beyit yukarıda gösterildiği şekilde Türkiye Türkçesine aktarılabilir.

2178, 2526, 2580, 2591, 2884, 4435 üzegü $\rightarrow$ üzeyü

\begin{tabular}{|c|c|}
\hline $\begin{array}{l}\text { Genince yörimek mi yigdür yayah } \\
\text { Ya ol kim üzeyüde kala ayah (2178) }\end{array}$ & $\begin{array}{l}\text { Yaya olarak yürümek mi gerek. } \\
\text { Ya atla gitmek üzengide ayak. }\end{array}$ \\
\hline $\begin{array}{l}\text { Güye gördiler üzejü gerdiler } \\
\text { At üstinde kaplan bigi turdılar (2526) }\end{array}$ & $\begin{array}{l}\text { Üzengiye sık1 basıp bekledi. } \\
\text { At üstünde kaplan gibi dineldi. }\end{array}$ \\
\hline $\begin{array}{l}\text { Helāllık dilendi dölendi göyül } \\
\text { Üzenü aġır oldı dizgin yüyül (2580) }\end{array}$ & $\begin{array}{l}\text { Helâllik dilendi, gönül açıldı. } \\
\text { Üzengi doldu ve dizgin tutuldu. }\end{array}$ \\
\hline $\begin{array}{l}\text { Ç1karurd1 1lduz gözini sünü } \\
\text { Aşınurdı depişmegin üzejü (2591) }\end{array}$ & $\begin{array}{l}\text { Süngü yıldız gibi gözünü çıkarırdı. } \\
\text { Üzengi şiddetle hareketten aşınırd1. }\end{array}$ \\
\hline $\begin{array}{l}\text { Üzenü gerüp cüst sıġadı kol } \\
\text { Yayı bağrınuy içine girdi ol (2884) }\end{array}$ & $\begin{array}{l}\text { Üzengiye basıp hem sığadı kol. } \\
\text { Yayı bağrının içine girdi ol. }\end{array}$ \\
\hline $\begin{array}{l}\text { Yağrınında kalhan elinde sünü } \\
\text { Ata bindi hiç çalmadı üzenü (4435) }\end{array}$ & $\begin{array}{l}\text { Sırtında kalkanı, elinde süngü } \\
\text { Ata bindi hiç vurmadı üzengi. }\end{array}$ \\
\hline
\end{tabular}

C. Dilçin yukarıdaki beyitlerde dikkat çekilen kelimeyi üzegü okumuştur. A. Cin de kelimeyi üzenü şeklinde okumuş ve sözlüğe aynı şekilde işlemiştir (Cin, 2012, s. 705).

Kanaatimce özellikle 2591. ve 4435. beyitlerde geçen örneklerde ilk dizenin sonundaki sü̈ü ile kafiyeli olacak şekilde kullanılmış olması, kelimenin üzenü şeklinde okunması gerektiğini gösteriyor. Ayrıca beyitlerde $m, n$, y ünsüzleriyle kurulmuş olan aliterasyon da bu okuma şeklini destekler. Söz konusu beyitlerin yukarıda gösterildiği şekilde anlaşılması uygundur.

2188 anan $\rightarrow$ ataj; ata: baba

\begin{tabular}{|l|l|}
\hline $\begin{array}{l}\text { Didi göresüm geldiyidi inen } \\
\text { 'Aceb midür isterse sini atan (2188) }\end{array}$ & $\begin{array}{l}\text { Dedi ki: İstedim seni ben görmek. } \\
\text { Ata özlemine şaşmak ne demek. }\end{array}$ \\
\hline
\end{tabular}

Araştırmacılar, yukarıdaki beytin son kelimesini anan okuyup 'ana' şeklinde anlamıştır (Dilçin, 1991, s. 2188; Cin, 2012, s. 144-15). Ancak bu okuma şekli ve anlam bağlama uymuyor. Çünkü Nevbahâr'1 görmeye gelen anası değil atasıdır.

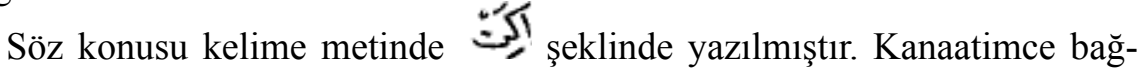
lama uymayan bu kelimenin yazılışı büsbütün yanlıştır. Burada muhtemelen yazıcının gözü birinci dizenin sonundaki inen kelimesine takıldığı için ikinci dizenin sonundaki atay kelimesini yanlışlıkla inen olarak yazmış olmalı. $\mathrm{Bu}$ nedenle kelime, bağlama uygun olarak atay okunup 'ata, baba' olarak anlaş1malıdır. Çünkü metnin bu kısmında babası, Nevbahâr'ı görmek üzere odasına gelmiş, Nevbahâr ise babasına neden konuklarını bırakıp kendisini görmeye geldiğini sormuştur. Babası yukarıdaki beyitle Nevbahâr'ın sorusuna cevap 
vermekte, açıklamada bulunmaktadır. Beyit, Türkiye Türkçesine yukarıda gösterildiği şekilde aktarılabilir.

2216 ag̉rımasun baya $\rightarrow$ ug̉ramasın buna, buya ug̉ra-: üzülmek, sıkıntıya düşmek

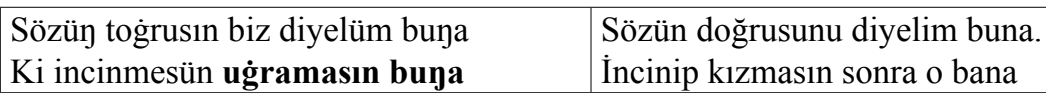

Yukarıdaki beytin ikinci dizesinin sonundaki iki kelime, M nüshasında $a \dot{g}$ rımasun baya okunacak şekilde yazılmıştır. C. Dilçin, yazmış olduğu dipnotta elindeki D. Dilçin nüshasında söz konusu deyimin uğramasın buja okunacak şekilde yazılmış olduğunu bilgi vermiş ancak buna rağmen deyimi $\mathrm{M}$ nüshasına uygun olarak ag̉rımasun bạa şeklinde okumuştur. M nüshasını çalışmış olan A. Cin de aynı okuma şeklini benimsemiştir (Cin, 2012, s. 146-14). Ancak bu okuma şekli bağlama uygun düşmüyor. Kanaatimce M nüshasındaki yazım şekli yanlıştır. Doğru yazım şekli, D nüshasındaki uġramasın buya olmalıdir.

Bu konuyla ilgili birinci gerekçe veya kanıt aǵrımasun baja ibaresinin metinde anlam vermemesidir. İkinci gerekçe için bir özet yapmak gerekiyor: Nevbahâr, Yemenli hizmetçi kılığına girerek babası ve iki kardeşinin de bulunduğu mecliste şarap sunmuştur. Nevbahâr'ın babası, kızını tanır gibi olur ve gördüğünün doğru olup olmadığını öğrenmek için meclisten ayrılarak kızının odasına gider. Ancak Nevbahâr, Süheyl ile kazmış oldukları tünelden geçerek babasından önce odaya gitmiştir. Babası gelip kızını odasında görünce şarap sunan hizmetçinin kendi kızı olmadığını düşünür ve sarhoşluk hâlinin sonucunda böyle bir zehaba kapıldığını düşünür ve meclise geri döner. Ancak kız tünelden geçip babasından önce meclise gelir. Olaya müdahil olan Nevbahâr'ın erkek kardeşleri babalarına böylesine yakın bir benzerlik olamayacağını ve şarap sunan kişinin kendi kız kardeşleri olduğunu söyleyip ısrar edince hükümdar bu defa iki oğlunu yanına alır ve onlarla birlikte Nevbahâr'ın odasına gider. Odaya vardıklarında Nevbahâr'ın satranç oynamakta olduğunu görürler. Hükümdar iki oğluna döner ve kızın günahını aldıklarını söyledikten sonra yukarıda verilen sözleri söyler.

Nitekim Tarama Sözlüğü’nde buna uğramak deyimi için "Sıkıntıya düşmek, kederlenmek, bunalmak" (TarS: 695) anlamları verilmiş ve biri yukar1daki söz konusu beyit olmak üzere üç tanık gösterilmiştir. Ayrıca aynı deyim, Süheyl ü Nevbahâr'da şu beyitlerde de geçer:

\begin{tabular}{|l|l|l}
\hline $\begin{array}{l}\text { Kamu çāresüzler sığınur saya } \\
\text { Buya uġradum merhamet kıl baya } \\
(2270)\end{array}$ & $\begin{array}{l}\text { Bütün çaresizler sığınır sana. } \\
\text { S1kıntıya düştüm, merhamet bana. }\end{array}$ \\
\hline
\end{tabular}




\begin{tabular}{|l|l|}
\hline İyen korhuban dėdi ey vay baya & Çok korkup dedi: Şimdi bana Eyvah! \\
Ne müşkil işe uğradum u buna (5074) & Ne zor belaya rastladım ben, vah vah! \\
\hline
\end{tabular}

2371 elikdürmiş idi $\rightarrow$ elikdürmemişdi

\begin{tabular}{l|l} 
Çeriler salup yā tanışup için & Yakalamak veya danışmak için \\
Elikdürmemişdi anı şāh-1 Çin (2371) & Askerle bile bulamaz şah-1 Çin.
\end{tabular}

C. Dilçin, yukarıdaki beyitte dikkat çekilmiş olan fiili, elikdürmiş idi şeklinde okumuştur. M nüshasını çalışmış olan A. Cin de aynı okuma şeklini benimsemiştir (Cin, 2012, s. 157-4). Ancak bu okuma şekli bağlama kesinlikle uymaz.

Bunun için bir özet yapmak gerekiyor: Metinde 2365. beyitten başlayarak Çin ülkesinde dağa çıkmış olan Saluk adındaki azılı haydut tanıtılmaktadır. Yukarıdaki beyitte ise Çin hükümdarının azılı haydut Saluk'u yakalama teşebbüslerinin sonuçsuz kaldığı ifade edilmiştir. Bu bağlama göre söz konusu fiilin metinde olumlu değil olumsuz şekliyle kullanılmış olması gerekiyor. Nitekim söz konusu fiil, M nüshasında elikdürmemişdi okunacak şekilde yazılmıştır.

2377 kazılu (< kazıl + lu), kazıl (<Ar. gazl): kıldan yapılmış ip

\begin{tabular}{|l|l|}
\hline Bahup iki at gördi ol kazılu & Hem bakıp iki atı gördü; ipli, \\
Eyerlü, uyanlu, tavulbāzlu (2377) & Zırhlı, dizginli üstelik eyerli \\
\hline
\end{tabular}

Araştırmacılar yukarıdaki ilk dizenin sonunda geçen ve metinde فَّف (= kazılu) şeklinde yazılmış olan kelime için "Kazığa bă̆lanmış” (Dilçin, 1991, s. 620b; Cin, 2012, s. 588b) anlamını vermişlerdir. Ayrıca Tarama Sözlüğü’nde “kazmak (atı) (II): Kazık çakıp atı bağlamak" (TarS: 2393) şeklinde bir madde başı yapılmış ve tanık olarak Süheyl ü Nevbahâr'dan yukarıdaki beyit ile aşağıda üzerinde ayrıca durulmuş olan 3544. beyit dişında bir tanık gösterilmemiştir (bk. 3544 notu). Ancak bu anlamlar bağlama uymaz.

Yukarıdaki söz konusu kelimenin anlamını belirlemek için önce bir özet yapmak gerekir: Çin'den kaçmak konusunda Nevbahâr ile anlaşmış olan Süheyl, iki at alarak kararlaştırdıkları yerde Nevbahâr'ı beklemektedir. Nevbahâr hazırlık yapıp yükte hafif pahada ağır mücevher alıp Süheyl'in olduğu yere gelecektir. Ancak Süheyl, Nevbahâr'1 beklerken yorulur, uykusu gelir ve atından aşağı inerek iki atın yularını eline dolayıp yere oturur. Süheyl, bir süre sonra beklediği yerde uykusuna yenik düşer. Yukarıdaki söz konusu beyitte de Haydut Saluk'un gelerek burada uyumakta olan Süheyl'in atlarını görmesi tasvir edilmektedir. Bu durumda anlatıcıdan atların kazığa bağlı olarak değil, atların yuları Süheyl'in elinde olacak şekilde tasvir edilmesi beklenir. İşte bu nedenle ilk dizenin sonunda kazılu okunacak şekilde yazılmış olan kelimenin anlamı "Kazı̆̆a bă̆lanmış" olamaz. 
İkinci dizede eyer+lü, uyan+lu, tavulbaz+lu bulunuyor. O hâlde bu üç kelimenin sonundaki $+l U$ isimden isim yapım ekinin yönlendirmesiyle $k a$ zllu kelimesini anlamaya çalışmak bizi doğru sonuca götürebilir. Kelimenin yapısının şöyle açıklanabileceğini düşünüyorum: kazı+lu $(<k a z l l+l u)$. Bunun doğru olduğunu araştırmak için sözlüklere bakmak yerinde olacaktır:

Steingass sözlüğünde ġazl kelimesi, "spun, thread" (Steingass, 1892, s. 887) (= eğirilmiş, iplik) olarak tanımlanmıştır.

Kâmûs'ta "el-gazl iplik eğirmek manasınadır" (Mütercim Asım Efendi, 2014, s. 4670) şeklinde bir tanım verilmiştir.

Tarama Sözlüğ̈̈'nde ise kazıl için “kıldan yapılmış ip" (TarS: 2392) tanımı geçer. Bu başlık altında verilmiş olan ikinci tanık şöyledir:

"Yular kazılı: 25, altı uçurdum köstek: 15" (TarS: 2392)

$\mathrm{Bu}$ tanık cümledeki kazll elbette bizim aradığımız kelimedir. Yine tanık cümlenin başındaki yular kazılı 'yular ipi' demektir. Yukarıda adını verdiğimiz sözlük tanımlarından ve özellikle Tarama Sözlüğ̈̈'ndeki tanım ve tanıktan hareketle Arapça gazl 'eğirmek' anlamındaki kelimenin, Osmanlı Türkçesinde ses değişmelerine uğraması sonucu kazll şeklinde ve 'kıldan yapılmış ip' anlamında kullanılmış olduğu anlaş1lıyor. Nitekim benzer ses değişmeleri Dede Korkut Oğuznameleri'nde de tespit edilmiştir: garib $>\operatorname{kar} p(+\operatorname{llg} a)$, galā > kala 'değerli', ġarā'ib > karayıp, ġarim 'düşman'> karım, gayrı > kayrl, gazab > kazap (bk. Özçelik, 2016/I, s. 93-94)

Akla şöyle bir soru gelebilir: Söz konusu kelime kazll şeklinde ise metinde neden kazıllu olarak kullanılmadı? Bunun iki sebebi vardır. Mesud, ikinci dizenin sonundaki tavulbazlu kelimesiyle kafiye kurmak ve vezini sağlamak endişesinden dolayı bir tasarrufta bulunmuş ve bu nedenle de kazılu şeklinde kullanmıştır.

2484 gaçar 'al, hile' $\rightarrow$ kaçar 'ayaklı, koşan, yürüyen'

Şunuy bigi divün elinden kaçar

Hoş idi kolay bulıcak her kaçar (2484)

Böylesi şeytandan kişi hep kaçar.

Emindi firsat bulunca her kaçar.

C. Dilçin, yukarıdaki ikinci dizenin sonundaki kelimeyi kaçar okumuş ve Derleme Sözlüğ̈̈'ne dayanarak "hilekâr" (Dilçin, 1991, s. 616) şeklinde anlamıştır.

S. Tezcan, bu anlamın metne uymadığına dikkat çekmiş ve kelimeyi $S \ddot{z} z$ Derleme Dergisi 588'e dayanarak gacar okuyup 'al, hile' şeklinde anlamak istemiştir. Tezcan, ikinci dizeyi ise "Fırsat bulunca her hile hoştu" (Tezcan, 1994, s. 33) şeklinde anladığını belirtmiştir. 
Kelimenin iki nüshada da kaçar okunacak şekilde yazılmış olması Tezcan'ın okuyuşunun doğru olamayacığını gösterir. Kanaatimce burada söz konusu kelimeyi yazım şekline uygun olarak kaçar okuyup tevriyeli kullanılmış olduğunu düşünmek daha iyi bir çözüm olacaktır. Yani fiilin ilk dizenin sonunda kaç- fiilinin geniş zaman çekimi, ikinci dizenin sonunda ise bir sıfat-fiil olarak kaçar 'ayaklı, koşan, yürüyen' şeklinde anlamak mümkündür. Böylelikle ilk dizede geçen (divüg) elinden kaç- deyimini de dikkate alarak ikinci dizeyi "Fırsat bulup elinden kaçan her ayaklı (= koşan, yürüyen) iyiydi (= emniyet içindeydi)" şeklinde anlamak bağlama gayet uygun düşer.

2523 bile 'bilir', böle 'böler'

\begin{tabular}{|l|l|}
\hline Ki oh atıcak keybürini bile & $\begin{array}{l}\text { Ok atacak vaktin uygunun bilir. } \\
\text { Ki ura pili bilden iki böle }\end{array}$ \\
Vurup fili belden ikiye böler.
\end{tabular}

S. Tezcan, yukarıdaki ilk dizeden anlam çıkaramadığını söylemiştir (Tezcan, 1994, s. 33-34). Steingass 1108'de gaibur ve Lessing 444'te keibür için "a kind of arrow used for long distances" (= uzun mesafeler için kullanılan ok) anlamı verilmiştir. Bu anlamdan hareketle söz konusu beyti yukarıdaki şekilde anlamak bağlama gayet uygun düşer. Nitekim söz konusu yukarıdaki beytin geçtiği bölümde Çin hükümdarının üstün savaşçılığ1 övgüyle anlatılmaktadır.

\section{7 seher $\rightarrow$ seker}

Dımışki ışıhdan şu kayın seher

Ötelerdi eyle sanasin meger (2597)

Araştırmacılar, 2597. beyti yukarıdaki şekilde okumuştur (Dilçin, 1991, s. 2597; Cin, 2012, s. 172-10). S. Tezcan, beyitte seher - meger arasindaki kafiyeyi tuhaf bulmuş ve konuyla ilgili olarak şunları yazmıştır:

Seher ile meğer arasında uyak yapılmış olması tuhaf. Ayrıca seher ile uygun bir anlam vermek bana uygun görünmüyor. Belki aslında burada seker ya da siner bulunmaktaydı, müstensih bunu anlamayıp سخَر yazmış olabilir. Beytin açıklanması gerekir. (Tezcan, 1994, s. 36).

Tezcan, bu yazım ve okuma şeklini tuhaf bulmakta haklıdır. Kanaatimce müstensihin gözü bir alt satırda geçen hemen sonraki beytin başındaki seher kelimesine takılmış ve söz konusu kelimeyi bu beytin ilk dizesinin başına yazmıştır. Kanaatimce burada yazılması gereken kelime seker olmalıdır. Buna göre beyti şöyle tamir edilip anlaşılabilir:

\begin{tabular}{|l|l|}
\hline $\begin{array}{l}\text { Dımışki ışıhdan şu kayın seker } \\
\text { Ötelerdi eyle sanasın meger (2597) }\end{array}$ & $\begin{array}{l}\text { Şamî miğferden şu kayın ok seker. } \\
\text { Öyle sanırsın ki delerek geçer. }\end{array}$ \\
\hline
\end{tabular}


2601 beglere $\rightarrow$ begler e!

\begin{tabular}{|l|l}
\hline Didi begler e! gördüyüz mi çeri & Dedi: Beyler a! Gördünüz mü çeri. \\
Savaş nice eylermiş ölüm eri (2601) & Nasıl savaşırmış ölüm erleri!
\end{tabular}

Yukarıdaki beyitte koyu harflerle yazılmış olan ibare, araştırmacılar tarafindan beglere (<begler $+e$ ) şeklinde okunmuş ve anlaşılmıştır (Dilçin, 1991, s. 2601; Cin, 2012, s. 172-14). Ancak bu okuma şekli ve anlam bağlama uymaz.

Kanaatimce söz konusu ibare, begler e! şeklinde; yani beyler kelimesinden sonra bir yönelme durumu eki $(+e)$ değil, bir pekiştirme sözcüğü bulunduğu düşünülerek okunmalıdır. Benzer örnekler için bk. 2903, 2910, 3175.

2670 yanıt-: cezayı karşılamak (?) $\rightarrow$ vazgeçirmek

\begin{tabular}{|l|l|}
\hline Suçuyuzı ben dileyem yanıdam & Affınız isteyim, affettireyim. \\
Gẻrü döndürem şāhı alam gidem (2670) & Şahı vazgeçirip hem götüreyim. \\
\hline
\end{tabular}

Araştırmacılar yukarıdaki beyitte geçen yanıt- fiilini anlamını "cezayl karşılamak" (Dilçin, 1991, s. 647a; Cin, 2012, s. 715b) şeklinde göstermiştir. Ancak bu anlam bağlama uymaz.

Tarama Sözlüğ̈̈ 4285'te sadece yukarıdaki beyit tanık gösterilerek fiil için aynı anlam, fakat tereddüt belirtilerek "cezayı karşılamak (?)" şeklinde verilmiştir. Aynı anlam Yeni Tarama Sözlügü̈ 234'te de aynı şekilde verilmiştir. Kanaatimce söz konusu fiil bu beyitte geçen, suç dile- 'af dilemek' deyimi dikkate alındığında yantt- fiilinin 'affettirmek' (bk. EDPT: 947) veya 'kararı geri aldırmak, vazgeçirmek' anlamında kullanılmış olması gerekir.

2793 1. bigiken $\rightarrow$ bilegen

2. bigiken $\rightarrow$ binegen

\begin{tabular}{|l|l|}
\hline Çerisin ü kavmin bėzer bilegen & $\begin{array}{l}\text { Askeri ve halkı donatır bilen. } \\
\text { Cihānı tamāmet gezer binegen }{ }^{1} \text { (2793) }\end{array}$ \\
Dünyayı tamamen gezer at ilen.
\end{tabular}

Yukarıdaki beytin iki dizesinin sonunda geçen iki fiil de araştırmacılar tarafından bigiken şeklinde okunmuş ve sözlükte bigiken kelimesine "Gibi iken" (Dilçin, 1991, s. 2793, 592b; Cin, 2012, s. 185-6, 458b) anlamı verilmiştir. Ancak bu okuma şekli ve anlam bağlama uygun düşmüyor.

İlk dizenin sonundaki kelime, $\mathrm{M}$ nüshasında bilegen 'çok bilgili, çok bilen' okunacak şekilde yazılmıştır. $M$ nüshasında ikinci dizenin sonunda ise kelime, binigen okunacak şekilde yazılmıştır. Kanaatimce metinde ilk dizenin sonu için bilegen 'çok bilgili, çok bilen' bağlama gayet uygun düşer. Ayrıca ikinci dizenin sonundaki fiilin harekelerinden sadece ikincisinde bir yanlışlık söz konusudur (üstün yerine esre). Anlaşılan şu ki D nüshası yazıc1s1, -ilk dize sonundaki bilegen kelimesini yazarken- gözünün bir sonraki dizede geçen bijegen kelimesine takılmış ve kelimeyi binegen okunacak şekilde 
yazmıştır. Yukarıdaki açıklamalar ikinci dizenin sonundaki kelimenin binegen 'atlı' okunması ve anlaşılması gerektiğini gösteriyor.

$\mathrm{Bu}$ açıklamalara göre beyitte konuşan kişi (Nakkaş), Süheyl’i çok bilgili ve dünyayı atlı olarak gezmekte olan bir kişi olarak tanıtmış oluyor.

2818 düş- $\rightarrow$ duş-: uygun olmak

Ne lāzım ki kaçar yabāna düşer

Gelüp kızumı alsun hem eyle düşer

Araştırmacılar, yukarıdaki beytin sonunda geçen fiili düşer 'düşmek' şeklinde okuyup anlamıştır (Dilçin, 1991, s. 2818; Cin, 2012, s. 187-1, 504a). Ancak bu okuma şekli ve anlam bağlama uymaz. Söz konusu fiilin duşar $(<d u s ̧-a r)$ okunup 'uygun düşer' şeklinde anlaşılması gerekir. Beyitte Çin hükümdarı vezir Nakkaş ile Süheyl hakkında konuşuyor. Hükümdar, Süheyl'in Nevbahâr'1 gelip kendisinden isteyip alabileceğini ve böyle davranmasının kızı kaçırmaktan daha uygun olacağını söylüyor. Bağlama göre beyti şu şekilde okuyup anlamak mümkündür:

\begin{tabular}{|l|l|}
\hline $\begin{array}{l}\text { Ne lāzım ki kaçar yabāna düşer } \\
\text { Gelüp kızumı alsun hem eyle duşar } \\
(2818)\end{array}$ & $\begin{array}{l}\text { Neden kaçıp ıssız yerlere varır. } \\
\text { Gelip kızım alsın, bu uygun olur. }\end{array}$ \\
\hline
\end{tabular}

Benzer düzeltmeler için bk. 1517, 3611, 3748, 5440 notları.

\section{3 ayrug் $+a \rightarrow$ ayrug்[-]a!}

$\mathrm{Bu}$ cehl ile ben kendüme işledügüm işi

'Aklı olan ayruga nitesi seze benven (2903)

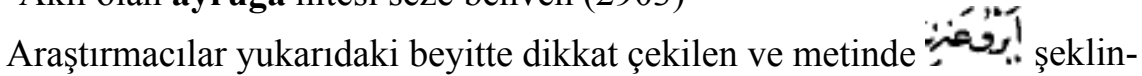
de yazılmış olan ibareyi ayrug்a okumuştur (Dilçin, 1991, s. 2903, Cin, 2012, s. 192-12). C. Dilçin'in kelimeyi işleyiş şeklinden kelime sonundaki $+a$ ile ilgili düşüncesi anlaşılmıyor (Dilçin, 1991, s. 588b). A. Cin'in kelimeyi işleyiş şeklinden ise kelime sonundaki $+a$ 'yı yönelme durumu eki olarak kabul ettiği anlaş111yor (Cin, 2012, s. 443b). Ancak ibareyi bu şekilde anlamak beyitte anlam vermez. Kanaatimce buradaki bağlama göre söz konusu $a$ bir ek değil bir pekiştirme edatı ( $a$ !) olmalıdır. Beyit, şu şekilde okunup anlaşılabilir:

\begin{tabular}{|l|l|}
\hline $\begin{array}{l}\text { Bu cehl ile ben kendüme işledügüm işi } \\
\text { 'Aklı olan ayrug̀[-]a! nitesi seze benven } \\
\text { (2903) }\end{array}$ & $\begin{array}{l}\text { Cehl ile kendime ettiğim işi } \\
\text { Nerden bilsin ben gibi akil kişi }\end{array}$ \\
\hline
\end{tabular}

Ayrıca pekiştirme edatı A!'nın başka örnekleri için bk. 2601, 2910, 3175 notlar1. 
2910 kıza $\rightarrow$ kız a!

\begin{tabular}{|l|l|}
\hline Benzeyimeyen er kişiye kim geze taşra & Erkek gibi dışarda gezen benim. \\
Yā perdeler içinde oturan kız a! benven & Kız ki perde ardında duran benim. \\
(2910) &
\end{tabular}

C. Dilçin (1991, s. 2910) ve A. Cin, (2012, s. 192-12) yukarıdaki beyitte dikkat çekilen ve metinde okumuştur. A. Cin'in kelimeyi işleyiş şeklinden kelime sonundaki $+a$ 'yı yönelme durumu eki olarak kabul ettiği anlaş1lıyor (Cin, 2012, s. 594a). Ancak ibareyi bu şekilde anlamak beyitte anlam vermez.

Kanaatimce buradaki $a$ ! bir pekiştirme edatı olmalıdır. Söz konusu beyti yukarıda aktarıldığı şekilde anlamak mümkündür. Pekiştirme edatı $a$ !'nın başka örnekleri için bk. 2601, 2903, 3175 notları.

2921 kurıdı $\rightarrow$ kıvand 1

Baya oldı ol uyhudan dinçlik

Süjügüm içinde kurıdı ilik (2921)

C. Dilçin, yazdığı dip notta yukarıdaki ikinci dizede geçen ve M nüshasında kurıd $\iota$ okunacak şekilde yazılmış olan kelimenin D'de kıvand $\imath$ okunacak şekilde yazılmış olduğunu belirtmiştir. Ancak araştırmacılar burada kelimeyi kurıd $ı$ okumayı tercih etmişlerdir (Dilçin, 1991, s. 2921; Cin, 2012, s. 1941). Ancak buradaki bağlama uygun olan tercih kelimeyi kurıdı değil kıvandı okumaktır.

Bunun için önceki iki beyiti $(2919,2920)$ de dikkate alarak metni tekrar okumak yeterli olacaktır:

Bi-güftā çünin est kavl-i Huzā
Ki rāhat komışdur Çalap uyhuda (2919)
Ne hoş uyhuyıdı ki ben yārumı
Düş içinde gördüm [çü] dildārumı
(2920)

Baya oldı ol uyhudan dinçlik Sünügüm içinde kıvandı ilik (2921)

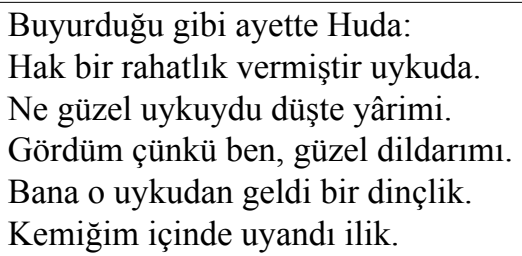

Türkiye Türkçesi ile aktardığımız kısımdan da anlaşılacağı gibi 2919. beyitte ayete işaret edilmiş ve Allah'ın "uykuda rahatlık vardır" dediği vurgulanmıştır. Bir sonraki 2920. beyitte ise Nevbahâr, çok güzel bir uyku uyuduğunu ve rüyasında sevgilisi Süheyl'i gördüğünü belirtmiştir. Ayrıca söz konusu beytin ilk dizesinde ise bu uykudan kendisine dinçlik geldiğini yani

1 “Geceyi örtü, uykuyu rahatlık, gündüzü çalışma vakti kılan Allah’tır.” (Kur’an, Furkan 47. ayet) 
dinlediğini ifade etmiştir. Bu durumda ikinci dizeye uygun olan fiil kesinlikle kurt- olamaz.

\section{3 göründügi $\rightarrow$ güvendügi}

\begin{tabular}{|l|l|}
\hline Vay ana ki güvendügi düş ola & Kim güvense düşe ona çok yazık. \\
Düşüy dahı bijde biri tuş ola (2923) & Düşün binde biri çıkar, bu açık. \\
\hline
\end{tabular}

C. Dilçin, yukarıdaki beyitte dikkat çekilen kelimeyi M nüshasındaki yazılışına uygun olarak göründügi şeklinde okumuştur. S. Tezcan, bu okuma şekli ile ilgili olarak "göründügi yerine D'deki güvendügi metne anlamca daha uygundur." (Tezcan, 1994, s. 39) diyerek tek cümlelik bir düzeltme teklifi yazmıştır. A. Cin, Tezcan'ın teklifini benimsememiş ve Dilçin gibi fiili yazılışına uygun olarak göründügi şeklinde okumayı tercih etmiştir (Cin, 2012, s. 194$3)$.

Söz konusu yukarıdaki beyitten iki beyit sonraki şu beyitte aynı konu işlenerek güven- fiilinin tekrar kullanılmış olması, Tezcan'ın düşüncesinde haklı olduğunu ve yaptığı teklifin doğru olduğunu gösteriyor:

\begin{tabular}{|l|l|}
\hline $\begin{array}{l}\text { Bu ālemde güci yèten işine } \\
\text { Güvenür[se] borca batar düşine (2925) }\end{array}$ & $\begin{array}{l}\text { Şu dünyada işine gücü yeter, } \\
\text { Güvenirse düşüne borca batar. }\end{array}$ \\
\hline
\end{tabular}

2924 göynügidür $\ddot{\mathbf{u}} \rightarrow$ göynügi durur

Hemin hāsıl öz göynügi dur u renc

Ki müflis kişi bula düşinde genç (2924)

Araştırmacılar, yukarıdaki ilk dizede dikkat çekilmiş olan kısmı öz göynigidür ü şeklinde okumuştur (Dilçin, 1991, s. 2924; Cin, 2012, s. 194-4). Ancak bu okuma şekli beyitte anlam vermiyor.

Söz konusu kısmın D nüshasında yanlış yazılmış olduğu ve araştırmacılar tarafindan bu nüshaya uygun şekilde okunduğu anlaşıllyor. Oysaki M nüshasında bu kısım doğru olarak öz göynügi durur okunacak şekilde yazılmıştır. Söz konusu doğru yazıma göre beyti şu şekilde okuyup anlamak gerekir.

\begin{tabular}{|l|l|}
\hline Hemin hāsıl öz göynügi durur renc & Müflisin düşte hazine görmesi \\
Ki müflis kişi bula düşinde genç (2924) & Yalnızca sıkıntı, yürek acısı \\
\hline
\end{tabular}

2932 1rış- 'uzaklaşmak'

Gide gide şöyle ırışdıyıdı

Ki deniz kenārına ėrişdiyidi (2932)

Gide gide o kadar uzaklaşt1

Ki bir deniz kıyısına ulaştı.

C. Dilçin, yukarıdaki ilk dizede dikkat çekilmiş olan fiili ırışdıyıdı okumuş ve irış- fiilini "yorulmak, bunalmak, bayılacak duruma gelmek" (Dilçin, 1991, s. 612) şeklinde anlamıştır. A. Cin ise fiili aynı şekilde okumuş ve "yorulmak, bunalmak" (Cin, 2012, s. 194-12, 558) şeklinde anlamıştır. 
Kanaatimce araştırmacıların fiili okuyuşları doğru ancak vermiş oldukları anlam yanlıştır. Bağlamın anlaşılması için bir özet yapmak gerekiyor: Nevbahâr, haydut ve hırsız Saluk'a bir oyun oynayarak ondan kaçmış, atıyla gece gündüz durmadan yol almış ve sonunda bir deniz kıyısına ulaşmıştır. Bu bağlama uygun olarak ilk dizenin sonundaki ırış- fiilini 'uzaklaşmak', ikinci dizenin sonundaki fiili ise ėriş- 'ulaşmak' olarak okuyup anlamak gerektiği açıtır.

2977 ışıt-d1 $\rightarrow$ işit-di

Kim işitdi kim ay yüzine demür

Ya oh yay peri duta kamu 'ömür (2977)

Kim işitti ay yüze peçe örter.

Peri, ömür boyu ok yayla gezer.

Araştırmacılar, yukarıdaki ilk dizede dikkat çekilmiş ve metinde şeklinde yazılmış olan fiili ışıtdı olarak okumuş (Dilçin, 1991, s. 2977; Cin, 2012, s. 197-12) ve "parlatmak" olarak anlamışlardır (Dilçin, 1991, s. 613; Cin, 2012, s. 559). Ancak bu okuma şekli ve anlam bağlama uymaz.

Söz konusu fiil, işitdi (<işit-di) şeklinde okunmalı ve 'işit-ti' olarak anlaşılmalıdır. Mesud burada Nevbahâr'ın yüzü peçeli ve zırhlı bir savaşçı kılı̆̆ında gezmesinin olağanüstü ve inanılmaz derece güç bir iş olduğunu anlatmak, okuyucuda hayranlık uyandırmak için istifham sanatına başvurarak soru soruyor. İkinci dizedeki $d u t$ - fiili sadece dizedeki ok ve yay ile değil, aynı zamanda üst dizedeki demür ile de ilgilidir. Çünkü eserde Nevbâhar'ın zırha bürünmüş, yüzü peçeli ve elinde ok yay ile dolaşmakta olduğu anlatıllyor. Bağlama göre söz konusu beyit yukarıda gösterildiği şekilde anlaşılabilir.

3062 oydı $\rightarrow$ oyıd $(<$ oy + i-di), işi oy: işi yolunda

\begin{tabular}{|l|l|}
\hline Çü Kaytās oturdı işi ołıdı & Kaytâs oturdu işi yolundaydı. \\
Ol aracuğ ol hücrenüy önidi (3062) & Nevbahâr odası tam önündeydi.
\end{tabular}

C. Dilçin, yukarıdaki beytin ilk dizesininin sonunda geçen kelimeyi ondl (Dilçin, 1991, s. 3062) şeklinde okumuştur. A. Cin de aynı okuma şeklini benimsemiştir (Cin, 2012, s. 203-6). Ancak bu okuma şekli beyitte anlam vermiyor.

Kanaatimce beyitteki yazım şeklinde bir hareke eksikliği söz konusudur. Buradaki deyim işi on (ol-) 'işi yolunda (git-)' olmalıdır. Buna göre deyim işi oyıd $l$ şeklinde okunmalı ve 'işi yolundaydı' olarak anlaşılmalıdır.

Süheyl ü Nevbahâr'daki şu beyitlerde ise işi on- 'işi yoluna girmek, işi yolunda gitmek' deyimi geçer:

\begin{tabular}{|l|l|}
\hline Çalap şallah oyara işüm oya & Allah izniyle işimi rast getirir. \\
Ve ger ni girü tiz irişem saya (763) & Aksi olsa beni sana gönderir. \\
\hline Ki andan girü oyasıdur işü̈ & Bundan böyle yoluna girer işin. \\
Gelüp tuzag̉a düşesidür kuşuy (1523) & Gelip tuzağına düşer o kuşun. \\
\hline
\end{tabular}




\begin{tabular}{|c|c|}
\hline $\begin{array}{l}\text { Bayık 'āşıkuy ol dem işi onar } \\
\text { Ki ma'şūk anuy geldügini öyer (1873) }\end{array}$ & $\begin{array}{l}\text { Yari yolunu beklerse şüphe yok. } \\
\text { Aşığın işi yoluna girer çok. }\end{array}$ \\
\hline $\begin{array}{l}\text { Sinarum sen olıcak aşum sijer } \\
\text { Çü ėşüm sen olasın işüm oyar (4449) }\end{array}$ & $\begin{array}{l}\text { Sen yanımda isen yemeğim siner. } \\
\text { Sen dostum olursan işim rast gider. }\end{array}$ \\
\hline $\begin{array}{l}\text { Ki ey şāhzāde ola mı düşüm } \\
\text { Ki gördüm yüzüni vü oydı işüm (4673) }\end{array}$ & $\begin{array}{l}\text { Ey şehzade, doğru mudur bu düşüm? } \\
\text { Yüzünü gördüm ve düzeldi işim. }\end{array}$ \\
\hline $\begin{array}{l}\text { Nèçe dürlü zahmet görürse kişi } \\
\text { Çü katlana sọ ucı ọar işi (4840) }\end{array}$ & $\begin{array}{l}\text { Ne kadar çok zahmet çekerse kişi } \\
\text { Katlanınca yoluna girer işi. }\end{array}$ \\
\hline
\end{tabular}

Nitekim şu beyitlerde ise işi sol (ol-) ve işi sol (düş-) deyimleri, 'işi ters (git-)' anlamında kullanılmıştır:

\begin{tabular}{|l|l|}
\hline Cevāb eyle vėrdidi nakkāşa ol & Nakkaş’a şöyle cevap verdi ol. \\
Ki oldı senüy işlerün kamu sol (1452) & Ki senin işlerin hepsi oldu sol. \\
\hline İşi sol düşüp düşmiş idi taġa & İşi ters gitti, düştü ıssız dağa. \\
Yilerdi gehi sola gāhi saġa (4067) & Koştururdu o, bir sola bir sağa. \\
\hline
\end{tabular}

Şu beyitte işi piç ol- 'işi karışmak' deyimi geçer:

\begin{tabular}{|l|l|}
\hline Eyitdi ki sabr eyle ag̉lama hiç & Dedi: Sabret ve hiç de ağlama sen. \\
İşün toğrıla nola oldısa piç (4837) & Biraz bekle işin düzelir esen. \\
\hline
\end{tabular}

3070 yoh! 'asla, kesinlikle!'

\begin{tabular}{|l|l|}
\hline Ne kuş kim çevüklikde oranı yoh & Öyle kuş ki çeviklikte eşi yok. \\
Simurġ elikdüreler anı yoh (3070) & Şu Simurg'u yakalarlar, onu yok.
\end{tabular}

Yukarıdaki beytin ikinci dizesinde geçen yoh kelimesi, 'asla, kesinlikle!' anlamında kullanılmıştır. Ayrıca ikinci dize, bu hâliyle yüklemi eksiltilmiş bir cümledir:

3158 degül, degül a! $\rightarrow$ degül 'ayb

\begin{tabular}{|l|l|}
$\begin{array}{l}\text { Ve likin bahāsın buyurun tamam } \\
\text { Degül 'ayb eger senden artuh umam }\end{array}$ & $\begin{array}{l}\text { Fakat değerini buyurun tamam. } \\
\text { Ayıp değil mi fazlasını ummam. }\end{array}$ \\
\hline $\begin{array}{l}(3158)\end{array}$
\end{tabular}

C. Dilçin, yukarıdaki beyitte dikkat çekilen kısmı degül a (Dilçin, 1991, s. 3158) şeklinde okumuştur. Dilçi dipnotta ise D nüshasında burada degül'den sonra ' $a y b$ kelimesinin bulunduğunu belirtmiştir. A. Cin ise M nüshasında yalnızca degül kelimesi bulunduğundan metindeki yazıma uygun okumayı tercih etmiştir (Cin, 2012, s. 209-11).

Ancak kanaatimce D nüshasındaki ' $a y b$ kelimesinin burada bulunması gerekiyor. Çünkü degül 'ayb veya 'ayb degül bir kalıp kullanım şeklidir denilebilir. Ayrıca ikinci dizede vurgu ve tonlama yoluyla bir istifham yapılmıştır: Fazlasını ummam ayıp değil (mi) = Senden fazlasını ummam ayıp olur. Benzer örnek için bk. 1834, 4029 notlar1. 
Nitekim şu iki beyitte de söz konusu kalıbın kullanılmış olması, tamir konusundaki düşüncemizi destekler:

\begin{tabular}{|l|l|}
\hline Degül 'ayb saçuma yapışdug̉uy & Ayıp değildir saçıma yapışman. \\
Ya karvanduğuy u yā kapışduğun (1756) & Sikıca sarılman veya kapışman \\
\hline Bahā biç dilekce senüydür tavar & Değerini biç sen, senindir bu mal! \\
Degül 'ayb bāzirgān assı kovar (3150) & Ayıp değil, tüccar kârı kovalar. \\
\hline
\end{tabular}

3164 1. almaya $\rightarrow$ olmaya

2. kız 'kız' $\rightarrow$ 'hiç, asla'

Ger ol hücrede gördügüm ise k1z

Bu deylü bahāyıla olmaya kız (3164)

Eğer gördüğüm o kıssa, odada.

Asla pahalı değil, bu fiyata.

C. Dilçin, yukarıdaki beyitte dikkat çekilen ilk kelimeyi iki nüshadaki yazılışına uygun olarak almaya şeklinde okumuştur. S. Tezcan, yazdığı notta, bu okuma şekli ile ilgili olarak şöyle demiştir:

almaya iki nüshada ortak bir istinsah yanlışıdır, olmaya olarak düzeltilmesi gerektiği kesindir. Yahudi bezirgân, Nev-bahâr için çok yüksek bir fiyat istediği hâlde Kaytas, "Eğer bu kız, o (gemideki) hücrede gördüğüm kızsa, bu fiyata pahalı sayılmaz" (bu denlü bahayile olmaya kı), diyor (Tezcan, 1994, s. 39).

A. Cin, Tezcan'ın teklifini atlamış veya benimsememiş olmalı ki fiili yazılışına uygun olarak almaya şeklinde okumayı tercih etmiştir (Cin, 2012, s. 210-2).

Tezcan'in olmaya ile ilgili teklifi bağlama uygundur. Ancak burada ikinci bir sorun bulunuyor. $\mathrm{O}$ da aynı dizenin sonundaki $k ı z$ kelimesini nasıl anlamamız gerektiği konusudur. Tezcan'1n bu beyti “Ĕger bu kız, o (gemideki) hücrede gördüğüm kızsa, bu fiyata pahalı sayılmaz." şeklinde anlamış olması ikinci dizenin sonundaki klz kelimesini de 'kız' olarak anladığını gösteriyor. Ancak kanaatimce beyitte ilk dizenin sonunda kullanılmış olan aynı kelimenin ikinci dizenin sonunda da kullanılmış olduğunu düşünmek bağlama uymaz. Çünkü Mesud, eserde beyit dizelerini aynı kelime ile sonlandırmaktan genel anlamda kaçınmış, kafiye kullanmaya özen göstermiştir. Bu nedenle ikinci dize sonundaki kız'ın farklı bir anlamda kullanılmış olması gerekiyor.

Yukarıdaki beyitte $k ı z$ kelimesinin 'kesinlikle, asla' anlamında kullanılmış olduğunu düşünüyorum. Aynı kelime Dede Korkut Oğuznameleri’ndeki şu cümlede de geçer:

“O ġlan bāzirgānlar hususından kız söz söylemedi, kāfirleri kırdug்ın aymadl." (Özçelik, 2016/II, s. 157-159). M. Ergin ve S. Tezcan, yukarıdaki cümlede geçen kız kelimesini -yanlış yazılmış düşüncesiyle- bir olarak okumuş; O. Ş. Gökyay, kelimeyi fazlalık görmüş ve okumamıştır. S. Özçelik ise söz konusu kelimeyi yazılışına uygun olarak kız şeklinde okumuş ve kelimenin 'hiç, hiç- 
bir şekilde, kesinlikle' anlamında kullanılmış olduğunu yazmış ve yukarıdaki söz konusu cümleyi "Oğlan tüccarlar konusundan hiç söz etmedi, kâfirleri kırdığını söylemedi" (Özçelik, 2016/II, s. 657) şeklinde aktarmıştır.

3310 kılınç, yaraşdur- $\rightarrow$ kılınç yaraşdur-: yaranmaya çalışmak

\begin{tabular}{|l|l|}
\hline Yaraşdurdı ol Nevbahāra kılınç & Nevbahâr'a yaranmaya çalışır. \\
Sanur kim [ki] renc ilte yiye birinç (3310) & Her zahmet çekeni pirinç yer sanır.
\end{tabular}

C. Dilçin, yukarıdaki beytin ilk dizesinde dikkat çekilmiş olan fiili sözlükte "kulınç 1. İşve, naz, eda" (Dilçin, 1991, s. 622) ve "yaraşdur- 1. yaraştırmak" (Dilçin, 1991, s. 648) şeklinde iki ayrı yerde işlemiştir. A. Cin ise fiili sözlükte "kllınç işve, naz, eda; davranış" (Cin, 2012, s. 592) ve "yaraştırmak, uygun biçimde yapmak" (Cin, 2012, s. 717) şeklinde işlemiştir.

Kanaatimce beyitte 'yaranmaya çalışmak' anlamında kllınç yaraşdurdeyimi kullanılmıştır. Bu nedenle deyimin sözlükte 'kılınç yaraşdur-: yaranmaya çalışmak' şeklinde işlenmesi ve anlaşılması gerekir. Mesud, beyitte Cuhud'un, içinde bulunduğu ruh hâli ve davranışı ile ilgili olarak yorum yapmakta ve onunla alay etmektedir. Çünkü hikâyenin bu kısmında Cuhud; Nevbahâr'ın istediklerini / söylediklerini bir bir yerine getirmekte ve Nevbahâr'a yaranmaya çalışmaktadır. Cuhud'un amacı veya niyeti Nevbahâr'dan faydalanmak ve onunla evlenmektir. Bağlama göre söz konusu beyit yukarıda gösterildiği şekilde anlaşılabilir.

3319 var- $\rightarrow$ ol

Binüp sandala çıhdı ol yazıya

Cühūdı gerek vire var bāziye (3319)

Araştırmacılar, yukarıdaki beytin ikinci dizesinde dikkat çekilmiş olan kelimeyi M nüshasındaki "צ yazım şeklini dikkate alalarak var okumayı tercih etmiştir (Dilçin, 1991, s. 3319; Cin, 2012, s. 220-10). Ancak bu okuma şekli anlam vermiyor. Çünkü ne bu metinde ne Tarama Sözlüğü'nde vire var- şeklinde bir deyim geçmez. Dilçin, yazdığ 1 dip notta D nüshasında burada ol kelimesinin bulunduğunu belirtmiştir. Kanaatimce beyit için uygun ve doğru olan kelime budur. Çünkü iki dizenin sonunda ol zamirinin tekrarı ile beyitte bir vurgu yapılmak istenmiştir. Buna göre beyit şöyle okunup anlaşılabilir:

\begin{tabular}{|l|l|}
\hline Binüp sandala çıhdı ol yazıya & Binip sandala gitti ova yana. \\
Cühūdı gerek vère ol bāziye (3319) & Cühûd'u getirmeliydi oyuna. \\
\hline
\end{tabular}

Nitekim şu beyitlerde de ol zamirinin aynı şekilde ve aynı yerde tekrarıyla bir pekiştirme ve vurgu yapılmıştır:

\begin{tabular}{|l|l|}
\hline Ki her nesnenüy yėgregin ol bilür & Çünkü işin iyisini o bilir. \\
Kamu derde dermānını ol kılur (38) & Hem dertlerin şifasını o verir. \\
\hline
\end{tabular}




\begin{tabular}{|l|l|}
\hline Kalur eyü adı eger ol ölür & Kalır iyi adı eğer o ölür. \\
Uzun ‘ömr dėdükleri ol olur (250) & Uzun ömür dedikleri şey olur. \\
\hline $\begin{array}{l}\text { Kapuyı açup girdi ol içerü } \\
\text { Ne dėyem neler gördi ol içerü (484) }\end{array}$ & $\begin{array}{l}\text { Kapıyı açıp girdi o içeri. } \\
\text { Ne diyem neler gördü o gözleri. }\end{array}$ \\
\hline $\begin{array}{l}\text { Ki sarp işi genez kılan ol durur } \\
\text { Kamu derde dermān vèren ol durur } \\
(643)\end{array}$ & $\begin{array}{l}\text { Çünkü zorları kolay kılan odur. } \\
\text { Bütün dertlere derman veren odur. }\end{array}$ \\
\hline $\begin{array}{l}\text { Benüm içün ol nėçe saçdıdı genc } \\
\text { Benüm içün ol nėçe yėdidi renc (3454) }\end{array}$ & $\begin{array}{l}\text { Benim için o hazine dağıttı. } \\
\text { Benim için o çok sıkıntı çekti. }\end{array}$ \\
\hline
\end{tabular}

3324 ırǵayı $\rightarrow$ arġa düz-: hile yapmak, oyun yapmak

\begin{tabular}{|l|l|}
\hline Gögercin ile düziser arg̉ayı & $\begin{array}{l}\text { Güvercin ile bir oyun kuracak. } \\
\text { Zi tāvūs ki azıdısar kargayı (3324) }\end{array}$ \\
\hline
\end{tabular}

C. Dilçin yukarıdaki beyitte geçen ve metinde olan kelimeyi ırg̉ayı okumuş ve sözlükte tereddüt belirterek kelimeye "çengel, kanca (?)" (Dilçin, 1991, s. 612b) şeklinde anlam vermiştir. S. Tezcan yazdı̆̆ 1 notta bu kelimenin metinde yanlış harekelenmiş olduğunu ve kelimenin Moğolca arg்a 'hile' olduğunu göstermiştir (Tezcan, 1994, s. 40-42).

A. Cin, S. Tezcan'ın bu notunu atlamış, C. Dilçin'in okuyuşunu benimseyerek kelimeyi 1rg̉ayı şeklinde okumuş (Cin, 2012, s. 220-15) ve sözlükte anlam olarak "çengel" (Cin, 2012, s. 558b) tanımını vermiştir. S. Tezcan'ın söz konusu notunu atlayan İ. Taş ise C. Dilçin'in verdiği anlamı doğru bulduğunu belirterek kelimeyi bağlama uygun düşmeyen $\operatorname{trg} a$ - ve $\imath \lg a$ - fiilleriyle açıklamaya çalışmıştır (Taş, 2015, s. 59-60).

S. Tezcan'ın kelimenin arg்a okunması ve 'hile' anlaşılması gerektiği şeklindeki tespiti doğru olmalıdır. Ancak beyitte deyimin arga düz-şeklinde kullanılmış olduğunu görerek sözlükte deyiminin 'arga düz-: hile yapmak, oyun kurmak' şeklinde işlenmesi gerektiğini belirtmek gerekiyor. Bu durumda beyit yukarıda gösterildiği şekilde anlaşılabilir.

Nitekim bu beytin devamında Nevbahâr, yıkanma bahanesiyle çadırda güvercini su dolu leğenin kenarına bağlar ve güvercin kanat çırptıkça sudan ses çıkar. Nevbahâr'ın yıkanmasını uzun uzun bekleyen Yahudi, su sesini dinlerken uyuya kalır. Nevbâhar bu arada çadırdan çıkıp atına binmiş ve bulundukları yerden uzaklaşmıştır. Söz konusu beyitte arga düz- 'hile yapmak' fiiliyle anlatılmak istenen de Nevbahâr'ın yaptığı bu oyundur. Ayrıca Süheyl ü Nevbahâr'da geçen şu beyitlerde aynı anlamda oyına vir-, oyın çıkar-, oyın getür-, oyın kar-, oyın oyna- deyimleri de geçer:

\begin{tabular}{|l|l|}
\hline $\begin{array}{l}\text { Ne oyın kamuyı virür oyına } \\
\text { Çevüklik ton imiş anū boyına (2208) }\end{array}$ & $\begin{array}{l}\text { Öyle ki kamuyu verir oyuna. } \\
\text { Kurnazlık giysiymiş onun boyuna }\end{array}$ \\
\hline
\end{tabular}




\begin{tabular}{|c|c|}
\hline $\begin{array}{l}\text { Ki çarh-1 felek perdeden nideyin } \\
\text { Dahı dürlü çıkarmış ola oyın (2673) }\end{array}$ & $\begin{array}{l}\text { Talih perdenin arkasından bana. } \\
\text { Türlü oyun oynar, ne yapam ona. }\end{array}$ \\
\hline $\begin{array}{l}\text { Bu gögercin ile getürem oyın } \\
\text { Revān uçuram seni keklikleyin (3305) }\end{array}$ & $\begin{array}{l}\text { Bu güvercinle bir oyun edeyim. } \\
\text { Seni bir keklik gibi uçurayım. }\end{array}$ \\
\hline $\begin{array}{l}\text { Didi kim benüm ile oyın karar } \\
\text { Gerek sevdügüm bile göylüm arar (3385) } \\
\text { Şāhin görse virmezdi ördek boyın } \\
\text { Karar idi kuzıyıla kurd oyın (3632) }\end{array}$ & $\begin{array}{l}\text { Dedi ki: O benimle oyun oynar. } \\
\text { Sevdiğimi bilmeye gönlüm arar. } \\
\text { Ördek, şahin görse eğmezdi boyun. } \\
\text { Hem kuzu, kurt görse oynardı oyun. }\end{array}$ \\
\hline $\begin{array}{l}\text { Gönül kapucı eyle oynar oyın } \\
\text { Ki baş koşdug่un bilse tartar boyun (1465) }\end{array}$ & $\begin{array}{l}\text { Gönül alıcı öyle oynar oyun. } \\
\text { Baş koyduğunu bilse eğer boyun }\end{array}$ \\
\hline
\end{tabular}

3335 1. [ol] $\rightarrow$ [vü]

2. çevür- 'çevirmek' $\rightarrow$ çevürr-: değiştirmek, felç etmek

\begin{tabular}{|l|l|}
\hline Yalıncagiiken çünki göre peri & $\begin{array}{l}\text { Beni çıplak iken görürse peri, } \\
\text { Ura yüzümi [vü] çevüre peri (3335) }\end{array}$ \\
Kanat vurur yüzümü eğer geri.
\end{tabular}

C. Dilçin, yukarıdaki beytin ikinci dizesinde gösterilen tamiri D nüshasına göre yapmıştır. S. Tezcan, yazdığı notta $\mathrm{M}$ nüshasında vü bulunmadığından yukarıdaki tamir yerine ol ekleyerek tamir yapılabileceğini savunmuş ve şöyle demiştir:

Burada cin çarpmasından söz edilmekte: Soyunup yıkanmak isteyen Nevbahâr galiba: "Peri beni çıplakken görecek olursa, kanadını çevirerek yüzümü çarpar" demek istiyor. Yani ikinci dizedeki kelimeyi perî değil, peri (per 'kanat' +1 akuzatif) olarak anlamak istiyorum (Tezcan, 1994, s. 39).

A. Cin ise dizeyi harhangi bir tamir yapmaksızın metindeki yazılışına uygun olarak okumuştur (Cin, 2012, s. 221-11).

Tezcan'ın cin çarpmasından söz edildiğini söylemesi ve per+ $i$ şeklindeki açıklaması doğrudur. Ancak kanaatimce ikinci dizenin ol eklenerek tamir edilmesi bağlalama uymaz. İkinci dizenin anlaşılması için çevür- fiilinin anlamını mutlaka dikkatle incelemek gerekir. Bu nedenle ikinci dizeyi “...kanadını çevirerek yüzümü çarpar" şeklinde anladığımızda eksiklik kalıyor ve anlam uygun düşmüyor. Beyitte çapraşı söyleyiş söz konusu olduğundan kelimelerin yeri çok değişmiştir. İkinci dizedeki $u r$ - fiili kanat ile çevir- fiili ise yüz ile ilgilidir. Dizede kelimeleri yerlerine koyduğumuzda kelimelerin bir cümle oluşturacak şekilde şöyle sıralanması gerekir:

peri ura [vü] yüzümi çevüre.

Ayrıca buna göre çevür- fiili, 'değiştirmek, felç etmek' anlamında kullanılmış olmalıdır. Gören herkesin âşık olduğu bir güzelliğe sahip olan Nevbahâr, buna vurgu yapmak için özellikle yüzünden -dolayısıyla yüz felcinden- söz etmiştir. Bu cümlenin öznesi ilk dizede geçen peri'dir. Yani Nevbahâr şunu 
söylüyor: Peri beni çılakken görürse kanat vuracak ve yüzümü değiştirecek (= felç edecek).

3418 1. irişdi $\rightarrow$ arışd1, arış-: yorulmak

2. rrışdı $\rightarrow$ èrişdi, èriş-: ulaşmak

\begin{tabular}{|l|l|}
\hline Üçünci gün ahşam arışdı idi & Üçüncü gün akşam pek yorulmuştu. \\
Aya dahı şöyle erişdi idi (3418) & Şöylesi bir yere hem ulaşmıştı. \\
Ki Bahar görür bir agaç̧ ol gece & Nevbahâr görür bir ağaç o gece. \\
Denizün kırayında bitmiş yüce (3419) & Deniz kıyısında büyümüş yüce. \\
\hline
\end{tabular}

C. Dilçin yukarıdaki 3418. beyitteki ilk dizenin yüklemini irişdi şeklinde okumuş ve "erişmek, ulaşmak, kavuşmak, varmak, yetişmek" (Dilçin, 1991, s. 614) olarak anlamıştır. A. Cin ise fiili èrişs di şeklinde okumuş (Cin, 2012, s. 227-3) ve "erişmek, ulaşmak, yetmek" (Cin, 2012, s. 512) olarak anlamıştır.

C. Dilçin aynı beytin ikinci dizesindeki yüklemi ırışdı okumuş ve "yorulmak, bunalmak, bayılacak duruma gelmek" (Dilçin, 1991, s. 612) şeklinde anlamıştır. A. Cin fiili, ırışd $l$ okumuş (Cin, 2012, s. 227-3) ve "yorulmak, bunalmak" (Cin, 2012, s. 558) şeklinde anlamıştır. Ancak bu okuma şekilleri ve anlamlar bağlama uymuyor.

Burada bağlam ve ilk fiilin kullanılışı ile ilgili olarak bazı açıklamalar yapmak gerekiyor. Önceki iki beyitte anlatıldığına göre Yahudi'ye bir oyun oynayarak gemiden kaçan Nevbahâr, iki gün geceli gündüzlü ve aç susuz yol almış, üçüncü gün deniz kıyısına ulaşmıştır. Bu nedenle beyitteki ilk cümlede geçen yüklemin arışdı okunacak şekilde yazılmış olması gerektiği kanaatindeyim. Yani fiilin ilk hecesinde bir harake yanlışlığı yapılmış -üstün yerine esre yazılmış- olmalıdır. Dolayısıyla fiili arışdı okuyup 'yoruldu' olarak anlamak, bağlama gayet uygun düşer.

Yukarıda da görüldüğ̈̈ gibi bir sonraki beyitte Nevbahâr'ın deniz kıyısına ulaştığında Yahudi'nin gemisinden çok uzaklaşmış olduğu ve kıyıda ulaşmış olduğu yerde büyük ve yükssek bir ağaç gördüğü anlatılmaktadır. Bu durum da ikinci dizenin yüklemi ėrişdi okunup 'ulaştı' şeklinde anlaşılması gerektiğini gösterir. Söz konusu iki beyit Türkiye Türkçesine yukarıda gösterildiği gibi aktarılabilir.

3481 aldılar $\rightarrow$ oydılar, oy-: rahatlamak

\begin{tabular}{|l|l|}
\hline Öküş gavgāā etdiler ü ondılar & Çok şamata edip rahatladılar. \\
Çü dün buçuğı olıcak dindiler (3481) & Gece yarı olduğunda sustular. \\
\hline
\end{tabular}

C. Dilçin, yukarıdaki beytin ilk dizesindeki oy- fiilinin anlamını "iyi olmak, iyileşmek, düzelmek" (Dilçin, 1991, s. 629) şeklinde göstermiştir. A. Cin ise fiili, M nüshasındaki yazılışına uygun olarak aldılar okumuştur (Cin, 2012, s. 221-11). 
S. Tezcan, yazdığg notta on- fiili için "3481a'ya dayanarak barışmak, anlamını da katabiliriz" (SÜN: 44) demiştir. Tezcan, yorumunu cümledeki iki fiilin (gavgāa et-, on-) iki zıt anlam ifade ettiğini kabul ederek / düşünerek yapmıştır. Ancak kanaatimce bu iki fiil aynı cümlede 'tezat' değil 'sebep sonuç' ilişkisi içerisinde kullanılmış olmalıdır. Çünkü dikkat edilirse ilk cümlenin yüklemleri ġavġā etdiler ü oydılar şeklinde kullanılmıştır. Buna göre oy- fiilinin anlamının öncelikle gavġā et- deyiminin anlamı ile birlikte ve onun sonucu olarak değerlendirilmesi gerekir. Tarama Sözlüğü'nde gavgāa sal- deyimi için "Ortalığl velveleye vermek" (TarS: 1611) anlamı verilmiştir. Söz konusu anlam yukarıdaki beyitte geçen ġavġā et- deyimi için de uygun görünüyor. $\mathrm{Bu}$ durumda bağlama göre oy- fiilinin anlamı 'rahatlamak' olmalıdır. Söz konusu beyit Türkiye Türkçesine yukarıdaki şekilde aktarılabilir.

3492 sapar 'kaçar'

\begin{tabular}{|l|l|}
\hline Ol arada hażır bulınur kapar & $\begin{array}{l}\text { Oralarda bulunur, beni kapar. } \\
\text { Su altına iltür gemiden sapar (3492) }\end{array}$ \\
Su altına çeker, gemiden sapar.
\end{tabular}

S. Tezcan, yukarıdaki ikinci dizenin sonunda geçen sapar'ı anlamlandırmanın güç olduğunu söyleyerek ve şu yorumu yapmıştır:

Burada sapar' 1 anlamlandırmak güç; "gemiden ayrılır" diye yorumlamanın mümkün olduğunu sanmıyorum; çünkü sap- daima 'dahaönce tutulan bir yönden ayrılmak' anlamını taşır. Burada sapar, $x$ istinsahı sırasında metne girmiş bir yanlış olabilir, daha önce burada belki çapar 'yağmalar, çalar' bulunuyordu (SÜN: 45).

Burada öncelikle bağlamı anlamak için bir özet yapmak gerekiyor: Beyitte konuşan Nevbahâr'a âşık olmuş olan Kaytas'ın kız kardeşidir. Nevbahâr, kıza bir deniz kıyısında rastlamış ve onunla tanışmıştır. Kız, kendisini Nevbahâr'a tanıtır ve Kusta şehir hükümdarının kızı olduğunu söyler. Bunu öğrenen Nevbahâr, kadının kendisine âş̧k olan Kaytas'ın kız kardeşi olduğunu anlar. Kaytas'ın kız kardeşi, bir gemiyle geziye çıktıklarında uyuyakaldığını ve bu sırada perilerin yöneticisi olan cin tarafından gemiden kaçırılıp denizin derinliklerine götürüldüğünü anlatır.

Metnin bu kısmında bir istinsah yanlışı olduğunu düşünmüyorum. Tezcan'ın sözünü ettiği çapar 'yağmalar, çalar' buradaki bağlama uygun düşmez. Çünkü beyitte bağlama uygun olan, yani kız kaçırma eylemini karşılayacak bir fiilin seçilmiş olması gerekiyor. Nitekim bu eyleme uygun fiil olarak ikinci dizede iltür 'götürür, kaçırır' geçmiştir. Söz konusu iltür fiilinden sonra aynı beyitte çapar 'yağmalar, çalar' buradaki eyleme / bağlama kesinlikle uygun düşmez. Bu durumda yine de ikinci dizenin sonunda neden sap- fiilinin kullanılmış olduğunu açıklamak gerekiyor. Beyitte sap- fiilinin kullanılmış olmasının tek sebebi ilk dizenin sonundaki kap-fiiliyle kafiye oluşturmak en- 
dişesidir. Mesud, kafiye tasarrufunu eserin birçok yerinde yapmıştır. Ancak bu, örneği az olan / görülen kelime seçimi veya tercihi konusunda yapılmış bir kafiye tasarrufudur (bk. Giriş). Ayrıca burada kullanılanılmış olan sap- fiili kapıp kaç- deyimi dikkate alındığında kaçar yerine ve aynı anlamda kullanılmış olduğu anlaşılmaktadır.

3544 kaza $(<$ kazuġa $<$ kazuh $+a)$, kaza ko-: kazığa bağlamak

\begin{tabular}{|l|l|}
\hline Revān indi vü kaza kodı atın & İndi, kazı̆̆a bağladı atını. \\
Ki gölgelene aldı turdı katın (3544) & Gölge için aldı onun katını.
\end{tabular}

Araştırmacıların yukarıdaki ilk dizede geçen kaza ko- deyimindeki kaza kelimesinin bir fiil olduğunu düşünmüş ve sözlükte "kaz-: kazığa bağlamak" (Dilçin, 1991, s. 620b; Cin, 2012, s. 587b) şeklinde işlemişlerdir. Ayrıca Tarama Sözlüğü'nde “kazmak (atı) (II): Kazık çakıp atı bağlamak” (TarS: 2393) şeklinde bir madde başı yapılmış ve tanık olarak Süheyl ü Nevbahâr'dan yukarıdaki beyit ile yukarıda üzerinde ayrıca durulmuş olan 2377. beyit dışında bir tanık gösterilmemiştir (bk. 2377 notu).

Ancak söz konusu kelime, bir fiil değil ses değişikliği tasarrufuna uğramış kazuh 'kazık' kelimesidir. Beyitteki kaza ko- fiili ise 'kazığa bağlamak' anlamında kullanılmıştır. Yani ilk dizede geçen kaza ko- deyimindeki kaza, iç hecede düşme / eksiltme yapılarak kullanılmış kazugga (<kazug் $+a)$ kelimesidir. Mesud, vezni sağlamak için kelimede böyle bir tasarrufta bulunmuş orta hecede eksiltme yoluna gitmiştir.

Nitekim aşağıdaki 3314. beyitte söz konusu kelime, kazuh şeklinde geçiyor.

Kız eydür alun bir legençe bile Atum dahı hem bile olsun hele (3313) Çayır otlaya tokıyasız kazuh Turu turu hamlamış ola yazuh (3314) Kız der ki: Alınız bir küçük leğen. Atımı dahi getiriniz hemen. At otlasın diye çakın bir kazık. Dura dura hamlamış o, çok yazık.

3574 ışııt- $\rightarrow$ ışı-: 1şımak, parlamak \begin{tabular}{|l|l|}
\hline Çü maşrikda ışıdı zengi dişi & $\begin{array}{l}\text { Doğuda 1şıyınca zenci dişli, } \\
\text { Habeş dutdı mağrib saru kaçışı (3574) }\end{array}$ \\
\hline
\end{tabular}

C. Dilçin'in yukarıdaki beyitte dikkat çekilmiş olan fiili ışıdı şeklinde okuyup sözlükte "lşılt- Parlatmak" (Dilçin, 1991, s. 613a) anlamını vermiştir. M nüshasını çalışan A. Cin ise fiili ışıtdı şeklinde okuyup, sözlükte "parlatmak" anlamını vermiştir (Cin, 2012, s. 197-12, 559).

Söz konusu fiil, M nüshasında 1şıdı okunacak şekilde yazılmıştır ve fiilin bağlama uyan okuma şekli de $\iota s ̧ ı d \imath(<\iota s ̧ l-d l)$, yani 'ışıdı, parladı' olmalıdır. Birinci dizede şafak vakti ortalığın aydınlanması, ikinci dizede ise ufuktaki 
karanlığın kaybolması anlatılıyor. Söz konusu beyit yukarıda gösterildiği şekilde anlaşılabilir.

3611 düş- $\rightarrow$ duş-: rastlamak

Nite düşdi bir gün kakıdı bana

Katı hışm ile bahdı bendin yaya (3611)

Araştırmacılar, yukarıdaki beytin sonunda geçen fiili düşdi 'düşmek' şeklinde okuyup anlamıştır (Dilçin, 1991, s. 3611; Cin, 2012, s. 240-1, 504a). Ancak bu okuma şekli ve anlam bağlama uymuyor. Söz konusu fiilin duşdı $(<d u s ̧-d l)$ okunup 'rastladı' şeklinde anlaşılması gerekir. Süheyl, önceki beyitlerde kendisini tanıtmakta ve başından geçenleri anlatmaktadır. Bu beyitte ise bir gün babasının kendisine rastlayıp öfkelendiğini anlatıyor. Bağlama göre beyti şu şekilde okuyup anlamak mümkündür:

\begin{tabular}{|l|l|}
\hline Nite duşdı bir gün kakıdı baya & Ne olduysa bir gün rastladı bana.
\end{tabular}

Katı hışm ile bahdı bendin yạa (3611) Büyük öfkeyle baktı benden yana.

Benzer düzeltmeler için bk. 1517, 2818, 3748, 5440 notları.

3649 tut-: ele geçirmek, zaptetmek

Ki fagifūr şāh dutdı Tūfān ilin

Tutup fitnenün kesdi ilden elin (Dilçin, 1991, s. 3649)

C. Dilçin, M nüshasında büsbütün karışık yazılmış olan bu beyti $\mathrm{D}$ nüshasından yararlanarak yukarıdaki gibi düzenlemiştir. A. Cin ise M nüshasındaki yazım şeklini olduğu gibi okumayı tercih etmiştir:

ki fag̉fürşāh og̣lı tūfān adı

tutup fitnenün kesdi ilden elin (Cin, 2012, s. 242-9)

M nüshasındaki yazım şeklinin eksik ve yanlış olduğu hem vezin hem de kafiye nedeniyle anlaşılmaktadır. Kanaatimce söz konusu beytin -M nüshası ve aliterasyon dikkate alınarak- şu şekilde tamiri uygun olacaktır:

Ki fag̉fūr şāh tutdı Tūfān ilin

Tutup fitnenüy kesdi ilden elin

C. Dilçin, beyitte geçen tut- fiilinin anlamını sözlükte göstermemiştir. A. Cin ise fiilin anlamını "tutmak; korumak; saklamak; bağlamak, dolamak" (Cin, 2012, s. 692) olarak vermiştir. Ancak bu anlamlar beyitteki bağlama uymuyor. Kanaatimce bu beyitte tut- fiili 'ele geçirmek, zaptetmek' anlamında kullanılmıştır. Nitekim Süheyl ü Nevbahâr'da geçen şu beyitte de fiil aynı anlamda kullanılmıştır: 
Anuy nimetin basdı vü ètdi güç

İli tutuban şāhı oldı son uç (4290)
Babama nankörlük edip zulmetti.

İli zaptedip kendini şah etti.

Fiilin bu anlamı Tarama Sözlüğü 1283 'te de tespit edilmiştir. Sözlükte verilmiş olan örneklerden biri şöyledir:

“Oğlanları üreyip Acem vilayetini Cengiz Hanîler tutmuştu.” (TarS: 1283).

Söz konuş beyti şu şekilde anlamak mümkündür:

Ki fag̀fūr şāh tutdı Tūfān ilin

Tutup fitnenün kesdi ilden elin (3649)

Çin'in şahı aldı Tûfân ilini.

İldeki fitnenin kesti elini

3672 yiyil- $\rightarrow$ yèyil-: yenilmek, mağlup olmak

Çü dil söze başlayıcak yiyile / yėyile

Vèrür çok başı yėle ol yiyile / yėyile (3672)

C. Dilçin, yukarıdaki iki dizenin sonunda dikkat çekilmiş, M'de ikisi de şeklinde yazılmış olan fiilleri yiyile okumuş ve "çürümek, aşınmak" (Dilçin, 1991, s. 652a) olarak anlamıştır. A. Cin ise fiili yejyil- (Cin, 2012, s. 244-3) şeklinde okumuş ve "çürümek, aşınmak; yeyilmek" (Cin, 2012, s. 726b) olarak anlamıştır. Yazım şekline göre fiili, yéyil- okumak uygundur. Ancak verilmiş olan anlamlar bağlama uygun düşmüyor.

Azerbaycan Türkçesi Sözlüğ̈̈’nde yèyil- fiilinin bir anlamı “...5. Birine yenilmek, mağlup olmak” (Altaylı, 1994, s. 1249b) şeklinde verilmiştir. Bu anlam yukarıdaki beyitte gayet uygun düşer ve söz konusu beyti aşağıdaki şekilde okuyup anlamak mümkündür:

Çü dil söze başlayıcak yėyile

Vèrür çok başı yèle ol yèyile (3672)
Dil yenilirse söze başlayınca.

Kendi de yenir başı kestirince.

Benzer düzeltmeler için bk. 235, 273, 4297, 4527, 4578 notlar1.

3784 düş- $\rightarrow$ duş-: olmak, vuku bulmak

Dėdi nite düşdi saya ey yigit

Ki zindāna düşdün baya bir eyit (3784)

Araştırmacılar, yukarıdaki ilk dizede dikkat çekilmiş olan fiili düşdi 'düşmek' şeklinde okuyup anlamıştır (Dilçin, 1991, s. 3784; Cin, 2012, s. 251-8, 504a). Ancak bu okuma şekli ve anlam bağlama uymuyor. Söz konusu fiilin duşdı $(<d u s ̧-d \imath)$ okunup 'rastladı' şeklinde anlaşılması gerekir. Haydut Saluk, Nevbahâr'ın huzuruna çıkarılmıştır. Nevbahâr, Saluk'u sorgulayarak başından neler geçtiğini ve nasıl olup da hapse düştügünü anlatmasını istiyor. Bağlama göre beyit şu şekilde okunup anlaşılabilir: 


\begin{tabular}{|l|l|}
\hline Dėdi nite duşdı sana ey yigit & Dedi: Yiğit, söyle ne oldu sana? \\
Ki zindāna düşdüy baya bir eyit (3784) & Neden buradasın bir anlat bana? \\
\hline
\end{tabular}

Fiil ile ilgili benzer düzeltmeler için bk. 1517, 2818, 3611, 5440 notlar1.

3876 yavu kul- $\rightarrow$ yavu k1l-: kaybetmek

\begin{tabular}{|c|c|}
\hline $\begin{array}{l}\text { Kara yüzlü Sa'lūk anı bulduġın } \\
\text { Hemān gėce yine yavu kılduğın (3876) }\end{array}$ & $\begin{array}{l}\text { Kara yüzlü Salûk onu bulduğun, } \\
\text { Aynı gece onu hem kaybettiğin, }\end{array}$ \\
\hline $\begin{array}{l}\text { Atamuz göre hem sevine seni } \\
\text { Seni bula çün yavu kıldı beni (3896) }\end{array}$ & $\begin{array}{l}\text { Hem babamız görür sevinir seni. } \\
\text { Seni bulsun madem yitirdi beni. }\end{array}$ \\
\hline $\begin{array}{l}\text { Ümizümi bulmış iken nideyim } \\
\text { Yavu kıldum u kancaru gideyim (4202) }\end{array}$ & $\begin{array}{l}\text { Umduğumu bulmuşken ne edeyim. } \\
\text { Kaybettim onu ben nere gideyim. }\end{array}$ \\
\hline $\begin{array}{l}\text { Apaysuzda yavu kılalı anı } \\
\text { Sınamış olalar görenler beni (4981) }\end{array}$ & $\begin{array}{l}\text { Birden kaybettim bulamadım onu. } \\
\text { Görenler görmüştür herhâlde beni. }\end{array}$ \\
\hline $\begin{array}{l}\text { Veli nėdelüm iy diriḡā vü āh } \\
\text { Ki uş yavu kılduk senüy bigi şāh (5426) }\end{array}$ & $\begin{array}{l}\text { Fakat nedelim, olan oldu eyvah! } \\
\text { İşte senin gibi yitirdik bir şah. }\end{array}$ \\
\hline
\end{tabular}

C. Dilçin yukarıdaki beş beyitte dikkat çekilmiş olan fiili, metindeki yaz1lışına uygun olarak yavu kul-okumuş ve sözlükte "yavu kul-Kaybetmek, yitirmek” (Dilçin, 1991, s. 649a) şeklinde işlemiştir. A. Cin de -yukarıdaki örneklerde- fiili aynı şekilde okumuş ve sözlükte yavu kul-(Cin, 2012, s. 720a) şeklinde işlemiştir.

Kanaatimce yazıcı yukarıdaki örneklerde yanlışlikla esre yerine ötre yazmış olmalıdır. Nitekim söz konusu fiil, 275, 1216, 1786, 3116, 3965, 4079, 5136. beyitlerde yavu kıl- okunacak şekilde yazılmıştır. Dilçin, bu örnekleri metindeki yazılışına uygun olarak yavu kıl- şeklinde okumuş ve sözlükte "yavu kıl-Kaybetmek, yitirmek" (Dilçin, 1991, s. 649a) şeklinde işlemiştir.

3973 ilin egle-r $\rightarrow$ al-ın ayla-r 'tuzağını anlar'

\begin{tabular}{|l|l|}
\hline Teferrüc ėdüp gọ̈lin egler idi & $\begin{array}{l}\text { Seyredip her gün gönlünü eylerdi. } \\
\text { Ne giderdi ne alın aylar idi (3973) }\end{array}$ \\
Ne giderdi ne tuzağı anlardı.
\end{tabular}

C. Dilçin (1991, s. 3973) ve A. Cin (2012, s. 264-2) yukarıdaki beyitte dikkat çekilmiş olan ibareyi ilin egler şeklinde okumuştur. Dilçin, hazırladığ1 sözlükte söz konusu kelimeleri işlememiştir. A. Cin ise kelimeleri il ve egleolmak üzere iki ayrı yerde işlemiştir (Cin, 2012, s. 566a ve 507b). Ancak bu okuma şekli anlam vermiyor.

Bağlam, ilin okunacak şekilde harekelenmiş olan ilk kelimenin alın $(<\mathrm{al}+\mathrm{in})$ şeklinde okunması ve 'hilesini' olarak anlaşılması gerektiğini gösteriyor. Bunun için bir özet yapmak gerekir: Kaytas, Nevbahâr'a âşık olmuş ve onun izini sürmektedir. Tufan şehrinin giriş kapısına gelir, Nevbahâr'ın havuz üzerindeki kubbede resmini görür. Kaytas, yaptığı soruşturmada ülke 
padişahının, bu resmi Tufan şehrinin dört kapısına yaptırdığını ve resme bakıp çok şaşıran, ağlayan veya gülen kişilerin tutuklanması yolunda emir verdiğini öğrenir. Bunları öğrenen Kaytas, şehrin giriş kapısının yakınında bir ev yaptırarak her gün resmi seyreder ve bu şekilde gönlünü avutur. Kaytas, kendi kız kardeşinden Nevbahâr'ın bu ülkeye padişah olduğunu daha önce öğrenmiştir. Kaytas'ın amacı yüzünü kimseye göstermek istemediğini söyleyen Nevbahâr'ın şehrin dört kapısına kendi resmini neden yaptırdığını öğrenmektir. İşte bağlama göre buradaki dizenin ne giderdi ne alın aylar idi okunması ve 'ne giderdi ne tuzağ 1 anlardı' olarak anlaşılması gerekir. Nitekim bir sonraki beyitte -Mesud'un yaptığ 1 yorumda- oyın 'hile' kelimesinin bu beyitteki anlamı pekiştirecek şekilde kullanılmış olduğu da görülüyor:

\begin{tabular}{|l|l|}
\hline $\begin{array}{l}\text { Güyerdi ki bir dünin ah u kara } \\
\text { Ne dürlü oyın perdeden çıkara (3974) }\end{array}$ & $\begin{array}{l}\text { Gece boyu beklerdi ak ve kara. } \\
\text { Perde ardından ne oyun çıkara. }\end{array}$ \\
\hline
\end{tabular}

Söz konusu beyit ise yukarıda gösterildiği şekilde anlaşılabilir.

3984 kişi $\rightarrow$ işi

\section{Okıdı hemān cevheriye kişi}

Gözi toh u gönüli arı kişi (3984)

Yukarıdaki okuma şekli, C. Dilçin'e aittir (Dilçin, 1991, s. 3984)

Aynı beyti A. Cin şöyle okumuştur:

Okıdı hemān cevher kişi

Gözi toh u gönüli arı kişi (3984) (Cin, 2012, s. 264-12).

$\mathrm{Bu}$ okuma şekliyle kafiye sağlanmamış olmaktadır. Bu nedenle beyitte bağlam ve anlama tekrar bakmak gerekiyor. Kanaatimce kafiye düzenine bakıldığında beyitte bir yazım yanlışlığı yapılmış olduğu anlaşılmaktadır. Yani asıl nüshada ilk dizenin sonunda kişi değil işi bulunuyordu. Ancak x nüshasında göz takılması veya bir yanılma sonucu ikinci dizenin sonundaki kişi kelimesi ilk dizenin sonundaki işi yerine yazılmış olabilir. Söz konusu okuma şekline göre işi ve kişi kelimeleri ile hem kafiye kurulmakta hem de anlam bütünlügü sağlanmaktadır. Nitekim mesnevide işi ve kişi kelimeleriyle birçok başka beyitte kafiye kurulmuştur. ${ }^{2}$ Bu açıklamalar ışığında söz konusu beyti şu şekilde okuyup anlamak mümkündür:

\begin{tabular}{|l|l|}
\hline Okıdı hemān cevheriye işi, & Çağırdı hemen bir kuyumcu kişi. \\
Gözi toh u gönüli arı kişi (3984) & Tok gözlü ve temiz gönlü hem işi. \\
\hline
\end{tabular}

$2172,187,206,233,277,378,421,569,576,607,713,753,820,830,930,1113,1118$, $1294,1310,1335,1393,1404,1423,1577,2283,2324,2395,2512,2995,3141,3177$, 3294, 3696, 3920, 3956, 3979, 3995, 4035, 4066, 4132, 4329, 4527, 4552, 4656, 4749, 4789, 4794, 4829, 4840, 5018, 5113, 5160, 5175, 5243, 5529, 5543, 5639, 5658. 


\section{9 [di]}

\begin{tabular}{|l|l|}
\hline Çıkardı vü vėrdi dėdi kim [di] tur & Çıkardı verdi ve dedi: Git yürü! \\
Satagör ki müflisligüm vaktidür (3989) & Bunu sat iflas ettim, ayak sürü.
\end{tabular}

C. Dilçin, yukarıda gösterilen tamirin yerinde D nüshasında metinde yazılmış olan ü bağlacinı okumuştur (Dilçin, 1991, s. 3989). A. Cin ise M nüshasını dikkate almış, herhangi bir tamir veya tercihte bulunmamıştır (Cin, 2012, s. 264-2). C. Dilçin'in tercihi beyitte anlam vermiyor. A. Cin'in tercihine göre ise beyitte vezin eksik kalmıştır.

Kanaatimce yukarıda gösterildiği gibi burada Dilçin nüshasındaki ü yerine di eklenerek dizenin tamir edilmesi metne gayet uygun düşer. Bu durumda beytin yukarıda gösterildiği şekilde anlaşılması uygundur. Nitekim Süheyl ü Nevbahâr'da bir yerde de olsa di! 'haydi' geçmiştir:

\begin{tabular}{|l|l|}
\hline Begendi Nakāşuy sözin Nevbahār & Nakkaş sözünü, beğendi Nevbahâr. \\
Öküş māl vėrdi di indi ki var (3723) & Çok mal verdi, dedi haydi şimdi var! \\
\hline
\end{tabular}

\section{Vurgu yoluyla soru}

Ki bir karavaş sanki hiç yok durur.

Şükür māluy u ni ‘metüy çok durur. (4029)

Kanaatimce yukarıdaki ilk dize, istifham sanatı yapılarak kurulmuş ve vurgu yoluyla desteklenmiş bir soru cümlesidir. İlk bakışta bunun anlaşılması biraz güç görünse de bağlam dikkate alındığında cümlenin bir soru cümlesi olduğu kolaylıkla anlaşılıyor. Bunun için metindeki bağlamı kısaca özetlemek gerekiyor. Yukarıdaki beyit, Cühud'un Nevbahâr'ı elinden kaçırdığı bölümde geçer (4023-4032. beyitler). Gemideki tayfalar, Nevbahâr'n kaçışına çok öfkelenmiş ve üzülmüş olan Cühud'u teskin edip teselli etmek için birtakım yorumlar ve öğütlerde verir, olayla ilgili yorumlar yaparlar. İşte söz konusu beyitteki sözler de Cühud'un tayfalarının yorumlarından biridir. Benzer örnekler için bk. 1834, 3158 notları. Bağlama göre beyit şöyle anlaşılabilir:

\begin{tabular}{|l|l|}
\hline $\begin{array}{l}\text { Ki bir karavaş sanki hiç yok durur. } \\
\text { Sükür māluy u ni‘metüy çok durur. } \\
(4029)\end{array}$ & $\begin{array}{l}\text { Sanki bir cariyecik hiç yok mudur? } \\
\text { Şükür malın ve nimetin çok durur. }\end{array}$ \\
\hline
\end{tabular}

4034 gidün $\rightarrow$ yèlün

Baya dirlik ansuz gerekmez bilüy

Beni kon varuy işünüze gidüy (4034)

Araştırmacılar yukarıdaki beyitte dikkat çekilen fiili gidün şeklinde okumuştur (Dilçin, 1991, s. 4034; Cin, 2012, s. 268-1). S. Tezcan, fiil için şunlar1 yazmıştır: 
Uyaksız olan bu beytin son kelimesi eserin aslında herhalde yèlüy "koşun!" idi. $1677 \mathrm{~b}$ 'de geçen işine süvār ol- 'kendi işine bakmak' ve bugün kullandığ1mız kendi işinin peşinden koş- deyimlerine göre Eski Osmanlıcada işine yèldeyiminin bulunabileceğini öne sürüyorum (Tezcan, 1994, s. 47).

Kanaatimce Tezcan'ın söz konusu fiilin asıl nüshada yèlün “koşun!” ile ilgili tahmini doğru fakat bununla ilgili olarak sunduğu gerekçesi yanlıştır. Çünkü burada işine bak- deyiminin farklı kelimelerle ifade edilmiş olması söz konusudur. Kullanılan fiilin değişmesi veya farklı kelime tercihi ise sadece kafiye tasarrufuyla açıklanabilecek bir konudur. Bunu göstermek için deyimin eserde kullanıldığı beyitlere bakmak yeterli olacaktır. Şu iki beyitte ikinci dizelerde var işüne yort ve işüne yort kullanılmış olmasının nedeni, ilk dizelerde geçen yurt ve dört kelimeleriyle kafiye kurmaktır:

\begin{tabular}{|l|l|}
\hline Eger bir bucah tuta vü süre yurt & Eğer bir yere gide, yurt edine. \\
Dėye söyleyene var işüne yort (2701) & Konuşana der: Haydi git işine! \\
\hline Eyitdi ki bu bir degül belki dört & Dedi: Bir değil bu, dört yerdedir bak! \\
Arada yazılmışdur işüne yort (3954) & Çizilmiş, git kendi işine ahmak! \\
\hline
\end{tabular}

Mesud, farklı beyitlerde aynı deyimi kafiye kurmak için farklı fiillerle kullanma yolunu seçmiş ve bir tasarrufta bulunmuştur. Nitekim aynı deyim, şu beyitte ilk dizenin sonundaki var kelimesi ile kafiye kurmak için işüye süvār ol- şeklinde kullanılmıştır:

Açılasıdur her ne kim rāzı var Bayık bil ü işǖje olg̀gl süvār (1677) Her ne gizli sırrın varsa açacak. Vaktidir bil! işin sırrın açarak.

Şu beyitte ise ikinci dizedeki nedesin ile kafiye kurmak için ilk dizede işü̈e gidesin şekli tercih edilerek kafiye kurulmuştur:

\begin{tabular}{|l|l|}
\hline $\begin{array}{l}\text { Gèrü işü̈e varasın gidesin } \\
\text { Bu zindān bucaġında sen nedesin } \\
(3786)\end{array}$ & $\begin{array}{l}\text { İşine hem yine çekip gidersin. } \\
\text { Zindan köşesinde sen ne edersin. }\end{array}$ \\
\hline
\end{tabular}

Yukarıdaki örnekler, kafiye endişesinin / tasarrufunun kullanılan kelimelerin tercihi konusunda etkili olduğunu göstermektedir. Buna göre söz konusu beyitte ilk dizenin sonunda bilü bulunduğu dikkate alıdığında Tezcan'ın Eski Osmanlıcada işine yèl-deyiminin bulunabileceği yönündeki tahmini isabetli değildir. Burada işaret edilmiş olan işü̋üze yèü̈ şeklindeki tamir, ancak yukarıdaki örnekler çerçevesinde doğru olarak yorumlanabilir. Buna göre de beyitte sadece kafiye kurmak için farklı bir fiilin (yèl-) tercih edilmiş olduğunu kabul etmek gerekli ve yeterlidir. Bu tür tasarruflar, okuyucunun rahatça intikal edebileceği işine git- deyimini kolaylıkla çağrıştıran ve anlama halel vermeyen tam tersine küçük bir dikkatle çözülebilecek bilmeceler tarzında geçici kullanımlar olarak görülmelidir. Sonuç olarak sondaki fiilin yèlụ̈ okunması ve beyitin şu şekilde anlaşılması uygundur: 


\begin{tabular}{|c|c|}
\hline 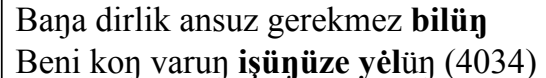 & $\begin{array}{l}\text { Bana onsuz hayat gerekmez bilin. } \\
\text { Beni bırakıp, ișinize yelin! }\end{array}$ \\
\hline
\end{tabular}

Nitekim şu beyitte de bil-ve yèl-fiilleriyle kafiye kurulmuştur:

\begin{tabular}{|l|l|}
\hline Benüm kadrümi ne kadar bilesin & Hem değerimi nereden bilesin. \\
Seni bilmedüm bu kadar yėlesin (3196) & Bilmezdim sen aceleci olasin. \\
\hline
\end{tabular}

4092 iş $\rightarrow$ uŞ

Ne iş işledüm kendüzüme ben uş

Bunū bigi hiç kimse görmemiş iş (4092) Böylesini hiçbir kimse görmemiş.

Yukarıdaki ilk dizenin sonunda geçen kelime, araştırmacılar tarafından iş şeklinde okunmuştur (Dilçin, 1991, s. 4092; Cin, 2012, s. 271-13). Ancak bu okuma şekli ve anlam bağlama uymuyor.

Kanaatimce söz konusu kelimenin yazımında bir hareke yanlışı yapılmıştır, yani ötre yerine esre yazılmıştır. Bu nedenle kelime $u$ ş şeklinde okunp ve 'işte' olarak anlaşılabilir. Beyit ise yukarıda gösterildiği şekilde anlaşılabilir.

4098 köy $\rightarrow$ göy üsti: gökyüzü

Çü yėrden sürükdi kömüri dünün

Göy üstinde yandı tenūrı günün (4098)

Gece kömürü yerden sürükledi, Gökte güneş, tandırı alevledi.

C. Dilçin, yukarıdaki beytin ikinci dizesinin başındaki kelimeyi köy okuyup “köz, kor” (Dilçin, 1991: 624b) şeklinde anlamıştır. S. Tezcan, bu okuma ve anlama karşı çıkmış ve kelimenin göy okunup 'gök' anlaşılması gerektiğini yazmıştır (Tezcan, 1994, s. 47). A. Cin de Tezcan'ın bu okuyuşunu dikkate alarak kelimeyi göy okumuş (Cin, 2012, s. 538b) ve kelimenin anlamını sözlükte "g̈̈y gök” (Cin, 2012, s. 538b) şeklinde işlemiştir.

Ancak burada bir ekleme yapmak gerekiyor. Beyitte geçen göy üsti tamlaması, 'gökyüzü' anlamında kullanılmış olmalıdır. Bu nedenle tamlamanın sözlükte madde başı yapılması ve anlamının 'gökyüzü' şeklinde verilmesi gerekir. Ayrıca söz konusu kelimenin Dede Korkut'ta da sadece şu cümlede göy şeklinde geçmiş olduğuna dikkat çekmek istiyorum:

“Kalın Og்uz begleri yüz göye tutdılar, el kaldurup du’ā eylediler.” (Özçelik, 2016/ I, s. 36a.8)

\section{4 didi $\rightarrow$ idi}

Anı görmege hasretüm bol idi Fiḡān èdüp ag̉laduğum ol idi (4124) Onu görmeye isteğim çok idi. Ağladığım başka bir şey yok idi.

Yukarıdaki beyitte ikinci dizenin sonundaki yüklem, araştırmacılar tarafından ol didi şeklinde okunmuştur (Dilçin, 1991, s. 4124; Cin, 2012, s. 273-15). 
Ancak bu okuma şekli beyitte anlam vermiyor. Nitekim fiil M nüshasında doğru olarak فُلْريك şeklinde yazılmıştır.

Metindeki yazım şekli ve bağlam yüklemin ol idi okunması gerektiğini gösteriyor. Söz konusu beyit ise yukarıda gösterildiği şekilde anlaşılabilir.

4227 uman $\rightarrow$ gümān iman

Olacah olur anda yohdur gümān

Hiç olmayasın eyle olur gümān

Araştırmacılar yukarıdaki beytin ikinci dizesinin sonunda dikkat çekilmiş olan kelimeyi uman (Dilçin, 1991, s. 4227) ve gümān (Cin, 2012, s. 28014) şeklinde okumuşlardır. Söz konusu kelime, M nüshasında ḉ (= gümān) şeklinde yazılmıştır. Dilçin'in dip notundan kelimenin D nüshasındaki uman okunacak şekilde yazılmış olduğu ve araştırmacının bu yazım şeklini tercih etmiş olduğu anlaşıliyor. Kanaatimce uman şekli, bağlama uymuyor.

Bağlama göre ilk kelimenin D nüshasındaki yazım şekli (olmayasın) doğrudur ve bunun tercih edilmiş olması isabetlidir. Ancak ikinci kelime, alur okunacak şekilde yazılması gerekirken iki nüshada da yanlışlıkla olur yazılmıştır. Şimdi ilk kelimenin yapısı ve ikinci dizeyi nasıl anlamamız gerektiği konusu üzerinde duralım. Öncelikle ilk kelimedeki gelecek zaman sıfat-fiilini görmek ( $a l-m a-\mathrm{y}-\mathbf{a s ı}+\mathrm{n})$ ve $a l$ - fiili ile $u m$ - fiillerini doğru anlamak gerekir. Dizedeki al-fiilinin 'elde etmek', um- fiilinin ise 'beklemek, sabretmek' anlamında kullanılmış olduğu kabul edilebilir: Hiç olmayacak sonucu öyle alır (=elde eder) bekleyen / sabreden. Söz konusu beyti şu şekilde okuyup anlamak mümkündür:

\begin{tabular}{|l|l|}
\hline Olacah olur anda yohdur gümān & Olacak iş olur, şüphe yok onda. \\
Hiç olmayasın eyle olur uman (4227) & Uman, olmaz işi alır sonunda. \\
\hline
\end{tabular}

4238 kırar $\rightarrow$ kıyar

Nęçeme kişiyi yazug̉a koyar

Sücidür ki kayġu tamarın kırar

Araştırmacılar yukarıdaki beyitte geçen ve metinde zılmış olan son kelimeyi yazılışına uygun olarak kırar şeklinde okumuştur (Dilçin, 1991, s. 4238; Cin, 2012, s. 281-10). İlk dizenin sonundaki koyar dikkate alındığında bu fiilin asıl nüshada kafiye gereği kıyar olması gerektiğini düşünüyorum. Bu nedenle fiili klyar 'keser' olarak okuyor ve beyti aşağıdaki şekilde anliyorum: 


\begin{tabular}{|l|l|}
\hline $\begin{array}{l}\text { Nėçeme kişiyi yazug̉a koyar } \\
\text { Sücidür ki kayġu tamarın kıyar (4238) }\end{array}$ & $\begin{array}{l}\text { Şarap nicesini günaha koyar. } \\
\text { Şarap her kaygının damarın kıyar. }\end{array}$ \\
\hline
\end{tabular}

4297 yıyıl- $\rightarrow$ yèyil: yenilmek, mağlup olmak

Yıyılubanın batıcagaz ${ }^{3}$ kana

Kılıçları katılmaz idi kına (4297)

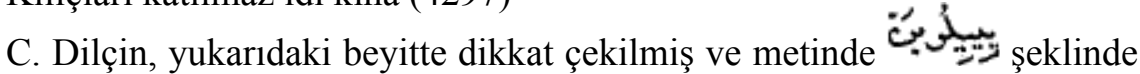
yazılmış olan fiili ylyıl- okumuş ve fiilin "Yayılmak, dağılmak (?)" (Dilçin, 1991, s. 650a) anlamına geldiği tahmininde bulunmuştur. A. Cin ise fiili aynı şekilde okumuş fakat tereddütsüz "Yayılmak, dă̆ılmak" olarak anlamıştır (Cin, 2012, s. 285-9 ve 727a). Bu okuma şekli ve verilmiş olan anlamlar bağlama uygun düşmüyor.

Yazım şekline göre fiili, yeyil- okumak uygundur. Nitekim Azerbaycan Türkçesi Sözlüğü’nde yèyil- fiilinin bir anlamı “...5. Birine yenilmek, mağlup olmak" (Altaylı, 1994, s. 1249b) şeklinde verilmiştir. Bu anlam yukarıdaki beyitte gayet uygun düşer ve söz konusu beyti aşağıdaki şekilde okuyup anlamak mümkündür:

\begin{tabular}{|l|l|}
\hline Yėyilübenin batıcaġaz ${ }^{2}$ kana & Mağlup olsa hem batsalardı kana. \\
Kılıçları katılmaz idi kına (4297) & Kılıçların komazlardı hiç kına. \\
\hline
\end{tabular}

Benzer düzeltmeler için bk. 235, 273, 3672, 4527, 4578 notları.

4332 öyirdür (<ön-ir-t-ür) $\rightarrow$ (<öy-ir+dür), öy-ir: hızlı

Dédiler sen istedügün bu ola

Ki yèlden öyirdür giricek yola (4332)

Araştırmacılar, yukarıdaki beyitte dikkat çekilmiş olan fiili sözlükte öyirtşeklinde işleyip "ileri geçmek" (Dilçin, 1991, s. 631a; Cin, 2012, s. 644b) olarak anlam vermişlerdir. Ancak fiilin yapısını bu şekilde yorumlamak ve fiili bu şekilde anlamak kesinlikle bağlama uygun düşmez.

Sorunun çözümü için bağlamın anlaşılması gerekir. İşte tam bu noktada mesnevinin söz konusu bölümü özetleyelim: Süheyl'i misafir etmekte olan kale beyi Calus, Nevbahâr'nn durumunu soruşturmak için Çin'e bir casus göndermek düşüncesindedir. Ancak bu iş için üç beş günden fazla zamanları yoktur. Çin'e gidip haber getirecek çok hızlı, yolu bilen ve becerikli bir kişinin bulunması için emir verilir. Verilen emir üzerine Calus'a beş on kişi getirilir. Getirilen koşucuların içinden en hızlısını seçerler. İşte bu en hızlı koşucuyu tanıtıp Calus'a takdim eden kişi, yukarıdaki beyitle söze başlar. Kanaatimce metnin bu bağlamına göre söz konusu yerde bir sıfat fiil yapısı ile karşı karş1-

3 M'de yıyıluban ınıgıcah şeklinde yazılmıştır. 
yayız. Beyitteki yèlden öyir'i ‘yelden hızlı' olarak anlamak gerekiyor. Beyitte bu yapının üzerine ek fiil getirilerek bir isim cümlesi kurulmuştur. Yani huzurdaki koşucu, "yola girdiğinde yelden hızlıdır" şeklinde tanıtılmıştır. Nitekim Türkiye Türkçesinde Öner, özel ad veya soyadı olarak kullanıldığını biliyoruz.

Yukarıdaki açıklamalara göre söz konusu beyit, şu şekilde okunup anlaşılabilir:

\begin{tabular}{|l|l|}
\hline Dédiler sen istedügün bu ola & Dedi: Senin aradı̆̆ın bu ola. \\
Ki yėlden öyirdür giricek yola (4332) & Ki yelden hıllıdır, koyulsa yola. \\
\hline
\end{tabular}

4342 döne $\rightarrow$ dön e!

İrişdür haber bize taşra döne

İki üç gün ü komaġıl biş güne (4342)

Yukarıdaki okuma şekli C. Dilçin'e aittir. Dilçin, beyitte dikkat çekilmiş olan fiili döne şeklinde okumuş fakat sözlükte işlememiştir. Bu okuyuştan hareketle araştırmacının bunu dön- fiilinin istek çekimi olarak anlamış ve yorumlamış olduğunu söylemek yanlış olmasa gerek. Nitekim A. Cin de fiili aynı şekilde okumuş ve anlamıştır (Cin, 2012, s. 288-9 ve 498b). Yukarıda 4332 notunda verilen özette Nevbahâr'dan ve Nakkaş'tan haber alma konusunda Süheyl'e yardımcı olmak isteyan Calus'un Çin'den haber getirecek bir koşucu bulduğu özet olarak anlatılmıştı. Olayın devamında haber getirmek için bulunan kişi huzura çıkarılınca Calus kendisine bir günde ne kadar yol koşabildiğini sorar (4334. beyit). Koşucu, günde otuz mil koşabildiğini cevap verince Calus, kendisinden hemen yola çıkmasını ve gece gündüz yol alarak üç günde Çin'e gitmesini, Nevbahâr ile Nakkaş'ın durumunu öğrenip haber getirmesini ister (4335-4341. beyitler). Bu isteklerde bulunan Calus, son olarak yukarıdaki beyitte geçen sözleri söyler.

Bağlama göre ilk dizenin sonundaki fiili döne okuyup istek çekimi olarak anlamak, kesinlikle bağlama uymaz. Kanaatimce fiili dön e! okuyup emir çekimi 2. teklik kişi çekimi üzerine $e$ ! pekiştirme edatı getirilmiş olduğunu düşünmek gerekiyor.

Yukarıdaki açıklamalara göre söz konusu beyit, şu şekilde okunup anlaşılabilir:

\begin{tabular}{|l|l|}
\hline $\begin{array}{l}\text { Ėrişdür haber bize taşra dön e! } \\
\text { İki üç gün ü komaġıl bėş güne (4342) }\end{array}$ & $\begin{array}{l}\text { Ulaştır bu haberi bizden yana. } \\
\text { İki üç günde, bırakma beş güne. }\end{array}$ \\
\hline
\end{tabular}

4360 öç 'kumar ve bahis parası' $\rightarrow$ uç vèr-: bilgi vermek, haber vermek

$\mathrm{Ol}$ araya on günde döküp gücin

Hayāl èrişür ise vèrem öcin (4360) 
Araştırmacıların yukarıdaki beyitte dikkat çekilmiş olan kelimeyi öc okumuş olmaları ve dolayısıyla kelime için vermiş oldukları "Kumar ve bahis parası" (Dilçin, 1991, s. 630a) ve "bahis parası" (Cin, 2012, s. 641a) anlamları kesinlikle bağlama uymuyor.

Burada konunun anlaşılması için bir özet yapmak gerekiyor: Nevbahâr ile Süheyl birbirini kaybetmiştir. Calus, Süheyl'i şehrinde ağırlamaktadır. Süheyl, veziri Nakkaş ve halkının Çin'deki durumunu ve onların başına neler gelmiş olduğunu merak etmekte onlar için endişe duymaktadır. Süheyl'e ev sahipliği yapan Calus, birkaç zenci koşucu çağırtır. Bu koşuculardan birini casus seçer ve kendisinden Çin'e giderek Nakkaş ve yanındaki Yemen halkının durumları hakkında bilgi toplamasını ve haber getirmesini ister. Calus, zenciye bu hizmetinin bedelini fazlasıyla ödeyeceğini söyler. Ayrıca burada iki taraf arasında bir bahis veya pazarlığa tutuşma da söz konusu değildir. Yine bağlam dikkate alındığında yukarıdaki beyitte konuşan kişinin zenci koşucu olduğu açıkça anlaşılmaktadır. Nitekim zenci koşucu, Çin'e gider ve beş gün içerisinde geri dönerek Nakkaş ile Yemen halkı hakkında Calus'a ayrıntılı bilgi getirir.

Kanaatimce buradaki bağlama göre beyitte bir bilgi edinme amaçlanmaktadir. Metinde bilgi getirecek olan zenciden "casus" diye söz edilmesi bunu gösteriyor. Bu nedenle söz konusu kelimeyi öcin şeklinde değil uç verr- deyimini de dikkate alarak (vèrem) ucın 'bilgi vermek, haber vermek' şeklinde okuyup anlamak gerekiyor. Nitekim Derleme Sözlüğ̈̈'nde uç vèrmek deyimi için Niğde Bor'dan "uç virmek 1. Herhangi bir şeyin ucu belirmek, 2. Sakll kalmış bir suç ortaya çıkmak" (DerS: 4023b) anlamlarında tespit edilmiştir. Ayrıca Süheyl ü Nevbahâr'da geçen aşağıdaki beyitlerde uç belür- '(sebep) anlaşılmak' geçmiş olması da bu görüşü destekler:

\begin{tabular}{|l|l|}
\hline Dönüp og̉lı eydür ki içmen süci & Oğlu dönüp dedi: Şarap içmeyin. \\
Bu az iş degül bir belürsin ucı (2511) & Bu ufak iş değil, önce bir bilin. \\
Hele dürişem nite kim ola güç & Hele çalışam, ne kadar olsa güç. \\
Bolay kim belüre bu arada uç (3721) & Umarım kolay bilinir iki, üç. \\
Belürmeyicegez şer ü şūr ucı & Kötü iyi bilinmezse sonucu, \\
Bu şirịn ki łatlu içeler acı (4448) & Bu tatlı içilendir pek çok acı. \\
\hline
\end{tabular}

Yukarıdaki açıklamalara göre söz konusu 4360. beyit, aşăğdaki şekilde okunup anlaş1labilir:

\begin{tabular}{|l|l|}
\hline Ol araya on günde döküp gücin & On gün güç harcayıp varam oraya \\
Hayāl èrişür ise vèrem ucın (4360) & Hayal gibi haber verem buraya \\
\hline
\end{tabular}

4412 yayasin $\rightarrow$ yaya $\sin$

Eger atayı görmege ayasın

Ya ögler olur isen ol yana sin (4412) 
C. Dilçin, yukarıdaki beytin ikinci dizesinin sonunda dikkat çekilmiş ve M nüshasında okumuştur (Dilçin, 1991, s. 612). Dilçin, bu okuma şeklini sözlükte işlememiş fakat başka beyitlerde geçen yaya kelimesi için "yana, tarafa" (Dilçin, 1991, s. 647a) anlamını vermiştir. A. Cin de iki kelimeyi birleştirerek yayasın (Cin, 2012, s. 293-4) şeklinde okumuş ve yaya kelimesi için aynı anlamı vermiştir (Cin, 2012, s. 715a). Ancak bu okuma şekli ve anlam bağlama uygun düşmüyor.

Kanaatimce yazım şekli, kafiye ve bağlam; buradaki doğru okuma şeklinin yaya sin şeklinde olması gerektiğini gösteriyor. Burada okuma yanlışına sebep olan iki konu vardır: Birincisi görmege ve yaya kelimelerinin yönelme durumu ekiyle kullanılmış olmasıdır. Ancak bu ek, iki örnekte de yükleme durumu yerine kullanılmıştır. Okuma yanlışına sebep olan ikinci konu ise ikinci dizenin sonunda sen zamirinin sin okunacak şekilde kullanılmış olmasıdır. Ancak sen zamiri, yukarıdaki örnek dişında dokuz yerde ${ }^{4}$ daha sin şeklinde; ben zamiri ise üç yerde ${ }^{5}$ bin şeklinde geçer: Eğer atanı görmeyi istersen / Veya düşünürsen o tarafı sen.

$\mathrm{Bu}$ durum da yukarıdaki okuma şeklini ve yorumu destekler.

4486 yakinen $\rightarrow$ yıkanın: yıktığını, devirdiğini

\begin{tabular}{|l|l|}
\hline Sünü kaldurup çün gözi kızdıdı & Öfkelense mızrak kaldırır idi. \\
Bèş on kişiyi şol să‘at dizdidi (4485) & Hemen beş on kişi devirir idi. \\
Sünüsinün ucına suya saya & Mızrağ1 vurmak, suya sokmak idi \\
Gerekdi kişi kim yıkanın saya (4486) & Düşeni saymaya biri gerekdi. \\
\hline
\end{tabular}

C. Dilçin, yukarıdaki ikinci beytin ilk dizesinin sonunda geçen ibareyi metindeki yazılışına uygun olarak soya soya okumuştur. S. Tezcan, yazdığı notta bu okuyuşun anlam vermediğini belirtmiş ve ibareyi suya saya okuyarak düzeltme teklifi yazmıştır. Tezcan, okuma teklifini şu beyite dayandırmışırı:

\begin{tabular}{|l|l}
\hline Ki kişi gerekdi anı sayası & Onu sayacak kişi gerek idi. \\
'Alemlüsi kaç idi vü sayası (5324) & Alemlisi, gömleklisi kaç idi.
\end{tabular}

A. Cin ise söz konusu ibareyi C. Dilçin gibi soya soya okumayı tercih etmiştir.

S. Tezcan'ın 4486. beyit ile ilgili olarak yaptığı bu yorum doğrudur. Ancak Tezcan, beytin ikinci dizesinde geçen ve metinde يَّكَ şeklinde yazılmış olup C. Dilçin'in yıkanın şeklinde okuduğu kelime için “Ben, bunun Arapça yakinen 'kesin olarak, tam olarak' yerine bir istinsah yanlışı olduğunu sant-

$4759,1191,1215,1218,1318,1418,1647,1907,2188$.

$52047,2048,2434$. 
yorum." (Tezcan, 1994, s. 53) demiştir. Tezcan'ın bu yorumuna katılmıyorum. Kanaatimce bu kelimenin yazılışında bir yanlışlık söz konusu değildir. Kelimeyi yazılışına uygun olarak yıkanın $(<y \imath k$-an $+\imath n)$ okuyup 'yık-tık+larını = yıktığı kişileri’ şeklinde anlamak yeterlidir. Buna göre de söz konusu beyitler yukarıda gösterildiği şekilde anlaşılabilir. Söz konusu kelimedeki - $A n$ sıfat-fiilinin benzer kullanılışı Dede Korkut'taki şu özlü sözde de geçer:

D4a.7: "At yemeyen ac1 otlar bitince bitmese yeg" = Atların yemediği acı otlar yeşermektense yeşermese daha iyi.

4527 yiyil- $\rightarrow$ yèyil-: yenilmek, mağlup olmak

Ne bilem ki anuy nolısar işi

Belāya sataşur yayılsa kişi (4527)

C. Dilçin, yukarıdaki beyitte dikkat çekilmiş ve metinde şeklinde yazılmış olan fiili ylyıl- okumuş ve fiilin "Yayılmak, dağılmak (?)" (Dilçin, 1991, s. 650a) anlamına geldiği tahmininde bulunmuştur. A. Cin ise fiili aynı şekilde okumuş fakat tereddütsüz "Yayılmak, dăğlmak" olarak anlamıştır (Cin, 2012, s. 300-15 ve 727a). Bu okuma şekli ve verilmiş olan anlamlar bağlama uygun düşmüyor.

Fiilin yazımındaki ilk üstün fazlalık olduğu anlaşılıyor. Bu harekeyi yok saydığımızda yazım şekline göre fiili, yeyil- okumak uygundur. Nitekim Azerbaycan Türkçesi Sözlüğü’nde yeyil- fiilinin bir anlamı “...5. Birine yenilmek, mağlup olmak" (Altaylı, 1994, s. 1249b) şeklinde verilmiştir. Bu anlam yukarıdaki beyitte gayet uygun düşer. Söz konusu beyti aşağıdaki şekilde okuyup anlamak mümkündür:

\begin{tabular}{|l|l|}
\hline Ne bilem ki anuy nolısar işi & Ne bilem ne olacak onun işi. \\
Belāya sataşur yẻyilse kişi (4527) & Belaya çatıp da yenilen kişi. \\
\hline
\end{tabular}

Benzer düzeltmeler için bk. 235, 273, 3672, 4297, 4578 notlar1.

4578 1. yiyil- $\rightarrow$ kayġu yèyil-: kaygılanmak, endişe duymak

2. yıyl- $\rightarrow$ yèyil-: yenilmek, mağlup olmak

Niçün kayğu andın yaya yiyile / yėyile

Ana ahmak olan kişi yıyıla (4578)

C. Dilçin, yukarıdaki ilk dizede dikkat çekilmiş ve metinde يُ şeklinde yazılmış olan fiili yiyil- (Dilçin, 1991, s. 4578) okumuş, fiili sözlükte işlemeyi unutmuştur (Dilçin, 1991, s. 650a). Ancak Dilçin, sözlükte 235, 273, 3672. beyitlerde yiyil- okuduğu fiil için "çürümek, aşınmak" (Dilçin, 1991, s. 652a) anlamlarını vermiştir. A. Cin ise fiili yèyil- (Cin, 2012, s. 304-7) okumuş ve 
“çürümek, aşınmak; yeyilmek” (Cin, 2012, s. 726b) anlamlarını vermiştir. Bu anlamlar bağlama uygun düşmüyor.

Yazım şekline göre ilk dizedeki fiili, yèyil- okumak ve kayg் yèyil- 'kaygılanmak, endişe etmek' olarak anlamak gerekiyor. Nitekim Azerbaycan Türkçesi Sözlüğ̈̈'nde yeyil- fiilinin bir anlamı “A ğıda çiğneyip yutulmak, mideye indirilmek" (Altayl1, 1994, s. 1249b) şeklinde verilmiştir. Bu anlam ilk dizeye gayet uygun düşer.

C. Dilçin, yukarıdaki ikinci dizede dikkat çekilmiş ve metinde "ئيَ şeklinde yazılmış olan fiili ise ylyıl- okumuş ve fiilin "Kendini kaptırmak (?)" (Dilçin, 1991, s. 650a) anlamına geldiği tahmininde bulunmuştur. A. Cin de fiili aynı şekilde okumuş, fakat tereddütsüz "Yayılmak, dağılmak" olarak anlamıştır (Cin, 2012, s. 304-7 ve 727a). Bu okuma şekli ve verilmiş olan anlamlar bağlama uygun düşmüyor.

Yazım şekline göre fiili, yèyil- okumak uygundur. Nitekim Azerbaycan Türkçesi Sözlüğ̈̈'nde yeyil- fiilinin bir anlamı “...5. Birine yenilmek, mağlup olmak" (Altaylı, 1994, s. 1249b) şeklinde verilmiştir. Bu anlam yukarıdaki beyitte gayet uygun düşer ve söz konusu beyti aşağidaki şekilde okuyup anlamak mümkündür:

\begin{tabular}{|l|l|}
\hline $\begin{array}{l}\text { Niçün kayğu andın yaya yėyile } \\
\text { Aya ahmak olan kişi yėyile (4578) }\end{array}$ & $\begin{array}{l}\text { Ondan yana niçin kaygı çekilir. } \\
\text { Ahmak olan kişi ona yenilir. }\end{array}$ \\
\hline
\end{tabular}

Benzer düzeltmeler için bk. 235, 273, 3672, 4297, 4527 notları.

4646 öyer- $\rightarrow$ ön-er, öy-: beklemek

\begin{tabular}{|c|c|}
\hline $\begin{array}{l}\text { Kişi kim süci içmek ohtın öyer } \\
\text { Gönül hoşluġila içerse sijer (4646) }\end{array}$ & $\begin{array}{l}\text { Kişi şarap içmek vaktini bekler } \\
\text { Gönül hoşluğuyla içerse siner. }\end{array}$ \\
\hline
\end{tabular}

C. Dilçin'in yukarıdaki beytin ilk dizesinde dikkat çekilmiş olan kelimeyi sözlükte "öyer-Geçmek, ileri geçmek" (Dilçin, 1991, s. 631a) şeklinde işleyip anlaması yanlış olmuştur. Çünkü anlam bağlama uymaz.

Söz konusu fiil ön-şeklinde okunmalı ve 'beklemek, intizar etmek' olarak anlaşılmalıdır. Yani burada ö̈- fiili geniş zaman çekimiyle kullanılmıştır. Nitekim fiil, şu beyitlerde de aynı anlamda kullanılmıştır:

\begin{tabular}{|l|l|}
\hline Ko halkı vü sen rızkūı andan öy! & Halkı bırak, rızkı sen bekle ondan. \\
Ki yaratdı ol rızkūı senden öy (217) & Çünkü yarattı o rızkını önden. \\
\hline Bayık 'āşıkuy ol dem işi oyar & Yari yolunu beklerse şüphe yok. \\
Ki ma'şūk anuy geldügini öyer (1873) & Ki aşığın işi yola girer çok. \\
\hline
\end{tabular}

A. Cin, yukarıdaki üç örnekten 217. beyitte geçen öy! 'bekle!' fiilini yanlış olarak öy ‘ön, huzur, yan’ (Cin, 2012, s. 644a) şeklinde anlamıştır. 
4678 kişi $\rightarrow$ kiçi

\begin{tabular}{|l|l|}
\hline Şu dẹlü ki andaġı ulu kiçi & Oradaki büyük küçük her kişi \\
Görüp her birinün yakıldı içi (4678) & Görünce hepsinin yanmaktı işi. \\
\hline
\end{tabular}

C. Dilçin, yukarıdaki beytin ilk dizesinin sonundaki kelimeyi kişi şeklinde okumuştur (Dilçin, 1991, s. 4678). A. Cin de aynı okuma şeklini benimsemiştir (Cin, 2012, s. 310-15). Ancak bu okuma şekli ve anlam bağlama uymuyor.

Bağlam, ilk dizede $u l u$ kiçi ‘büyük küçük’ ikilemesi bulunduğunu ve buna göre kelimenin kiçi okunması gerektiğini gösteriyor. Nitekim söz konusu kelime, M nüshasında kiçi okunacak şekilde yazılmıştır.

4684 ü urışuban $\rightarrow$ üvriş-üben (<üvür-iş- < evür-iş-): kaçışmak

\begin{tabular}{l|l}
\hline İyen çoh turışduk u dürişüben & $\begin{array}{l}\text { Çokça karşı koyup hem gayret ettik. } \\
\text { Dönüp de kaçmadık hem kaçışmadık. }\end{array}$
\end{tabular}

Araştırmacılar, yukarıdaki beytin sonunda dikkat çekilmiş olan ve metinde

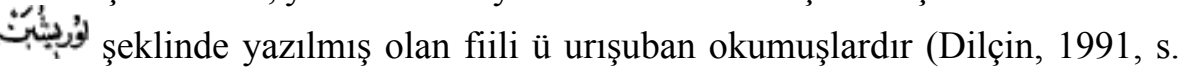
4684; Cin, 2012, s. 311-6). Ancak bu okuma şekli ve anlam beyitteki bağlama uygun düşmüyor.

Bağlama göre söz konusu fiilin üvrişüben okunması ve ‘kaçışmak' olarak anlaşılması gerekiyor. İkinci dizede geçen kaçmaduh fiili de bunu gösteriyor. Beyit, yukarıda gösterildiği şekilde anlaşılabilir. Benzer okuma yanlışı ve düzeltme için bk. 3753.

4714 1. el ayah ur- $\rightarrow$ el ayah ür-: gayret etmek

2. baş taşa yasdan-: güçlüklere katlanmak

\section{El ayah uram baş taşa yasdanam}

Dürişem varam yārumı isteyem (4714)

C. Dilçin, yukarıdaki beyitte dikkat çekilmiş ve metinde de yazılmış olan deyimi el ayah ur- şeklinde okumuş ve deyim için "Israr etmek, tepinmek" (Dilçin, 1991, s. 604b) anlamlarını vermiştir. A. Cin de deyim için aynı anlamı vermiştir (Cin, 2012, s. 508b). Ancak bu anlam beyitte uygun düşmüyor.

İkinci dizedeki anlama dikkat edildiğinde birinci dizedeki fiilin 'elini çabuk tutmak' anlamında kullanılmış olması gerektiğini düşünüyorum. Yani bu deyimdeki fiil, ur- değil ür- olmalıdır: ür- (<üvür- <evür-). İlk dizedeki 'güçlüklere katlanmak' anlamında kullanılmış olan baş taşa yasdanmak deyimi ile bu deyim anlaşıldığında dizede anlam bütünlüğü sağlanmış olmaktadır. Buna göre söz konusu beyit şu şekilde okunup anlaşılabilir: 


\begin{tabular}{|l|l|}
\hline El ayah ürem baş taşa yasdanam & Elim çabuk tutup taşa baş koyam. \\
Dürişem, varam yārumı isteyem (4714) & Gayret edip yârim izin arayam. \\
\hline
\end{tabular}

4731 toya $\rightarrow$ döye; döy-: katlanmak

Vay aךa ki buyruh degül kendüye

Gerek dürlü dürlü belāya toya (4731)

Yukarıdaki ikinci dizenin sonunda M'de toya, D'de döye geçmektedir. Araştırmacılar bu fiillerden M'deki toya 'doya' şeklini tercih etmişlerdir (Dilçin, 1991, s. 4731; Cin, 2012, s. 314-6). Hem kafiye hem de anlam bakımından D'de geçen döye 'katlana, tahammül ede!' fiilinin metne daha uygun / yakışan fiil olduğunu düşünüyorum: "Yazık ki nefsine hakim olamayan kişi türlü belalara katlanmak zorunda kalır.” Buna göre beyti şu şekilde okuyor ve aktarıyorum:

\begin{tabular}{|l|l|}
\hline Vay ạa ki buyruh degül kendüye & Yazık, hâkim olamayan nefsine. \\
Gerek dürlü dürlü belāya döye (4731) & Türlü belalar yükletir kendine. \\
\hline
\end{tabular}

4780 iken $\rightarrow$ inen: iyice, çok

\begin{tabular}{|l|l|}
\hline $\begin{array}{l}\text { Ki bu zulmi hadden geçürdi igen } \\
\text { Unutdı degül Tangrısını ijen (4780) }\end{array}$ & $\begin{array}{l}\text { Ki bunun zülmü sınırı çok aştı. } \\
\text { Allahı unuttu haddini şaştı. }\end{array}$ \\
\hline
\end{tabular}

C. Dilçin, yukarıdaki beytin ilk dizesinin sonundaki kelimeyi iken (Dilçin, 1991, s. 4780) şeklinde okumuş, A. Cin de aynı okuma şeklini benimsemiştir (Cin, 2012, s. 317-11).

Ancak bu okuma şekli bağlama uygun düşmüyor. Söz konusu kelime inen okunmalı ve 'iyice, çok' olarak anlaşılmalıdır. Bu durumda beyit, yukarıda gösterildiği şekilde anlaşılabilir.

4806 gördügin $\rightarrow$ gör dögin!

Süheyle dèdi anda ol gördügin

Anuy bigi sūret bahup gördügin

Araştırmacılar yukarıdaki iki dizenin de son kısmını gördügin şeklinde okuyup 'gördüğün' şeklinde anlamıştır (Dilçin, 1991, s. 4806; Cin, 2012, s. 319-7).

Bu okuma şekline göre beyitte yalnızca redif olduğundan okuma şeklinin sorgulanması, yani okuma şekli üzerinde durulması gerekir. Kanaatimce bunlardan birinci dizenin sonundakini gör dögin şeklinde okumak bağlama uygun düşer. Çünkü söz bu beyitte bitmemiş bir sonraki beyite taşmıştır. Mesud'un bu uzun mesnevide kafiye için bazen anlamı ikinci plana ittiği (Dilçin, 1991, s. 141) de dikkate alındığında beyitleri şu şekilde okuyup anlamak mümkün olabilir: 


\begin{tabular}{|l|l|}
\hline Süheyle dėdi anda [ol] gör dögin & Süheyl'e dedi orada gör dövün, \\
Anuy bigi sūret bahup gördügin (4806) & Bakıp böylesi bir resmi gördüğün \\
Ki hiç kimse ancılayın yazmaya & Ki hiç kimse öylesini çizmedi. \\
Degül yaza rengin dahı ezmeye (4807) & Ne çizmek, boyasın bile ezmedi. \\
\hline
\end{tabular}

4875 sende $\rightarrow$ bende

\begin{tabular}{|l|l|}
\hline $\begin{array}{l}\text { Dahı hem ugurlayın aylatdı ol } \\
\text { Ki bir nesne var bende sen bilmiş ol } \\
(4875)\end{array}$ & $\begin{array}{l}\text { Gizlice ona anlatıverdi ol. } \\
\text { Dinle bende bir sır var, sen bilmiş ol. }\end{array}$ \\
\hline
\end{tabular}

Araştırmacıların yukarıdaki ikinci dizede dikkat çekilmiş olan kelimeyi sende okuması yanlış olmuştur (Dilçin, 1991, s. 4875; Cin, 2012, s. 324-2).

Bağlam bu kelimenin bende okunacak şekilde yazılmış olması gerektiğini gösteriyor. Yani metinde bir yazım yanlışlı̆̆ yapılmış bende yerine sende yazılmıştır. Nitekim söz konusu kelime M nüshasında bende okunacak şekilde yazılmıştır. Bu okuma şekline göre beyit, yukarıda gösterildiği şekilde anlaş1labilir.

\section{1. vü güne $\rightarrow$ dügüne}

2. etdiler (<eyitdiler): söylemek, davet etmek

Buyurdı kim ol şarı tonatdılar

\section{Münādi ile vü güne itdiler (5089)}

Yukarıdaki beyit M nüshasında geçmez. C. Dilçin, beytin ikinci dizesinde dikkat çekilmiş olan kısmı, vü güne itdiler şeklinde okumuştur. Ancak bu okuma şekli bağlama uymuyor.

Kanaatimce metnin bu kısmında bir yazım yanlışı bulunuyor. Yazıcı burada yanlışlıkla dal yerine vav yazmıştır. Bu nedenle söz konusu ibare dügüne etdiler şeklinde okunmalıdır. Ayrıca ikinci dizedeki etdiler ile ilgili bir açıklama da yapmak gerekiyor. Bağlama göre bunun eyitdiler'den kısaltma olduğunu (etdiler < eyitdiler) düşünmek yanlış olmasa gerek. Çünkü ilk dizede şehri düğün için donatma emri verilmiş olduğu anlatıldığına göre ikinci dizede düğüne yapılan davetten söz edilmiş olması gerekir. Yani ikinci dizede münadi 'haberci' tarafindan halka duyuru yapıldığı ve halkın dügüne davet edildiği ifade edilmiş olmalıdır. Buna göre beyit, şu şekilde okunup Türkiye Türkçesine aktarılabilir.

\begin{tabular}{|l|l}
\hline Buyurdı kim ol şarı tonatdılar & Emir verdi, o şehri donattılar. \\
Münādi ile dügüne etdiler (5089) & Münadiyle toya davet ettiler.
\end{tabular}


5193 ırışmışuz $\rightarrow$ èrişmişüz, èriş-: kavuşmak

\begin{tabular}{|l|}
\hline Soy ucı ki Tūfān şārında karār \\
Tutup şükr kim olmışuz şehriyar \\
Biri birümüz ile èrişmişüz \\
Hikāyetlerümüzi soruşmışuz $\quad$ (5192- \\
5193)
\end{tabular}

Sonunda Tûfân'da il tuttuk karar. Şükürler olsun ki olduk hükümdar. Birbirimiz ile hem kavuşmuşuz. Hikâyelerimizi konuşmuşuz.

C. Dilçin, yukarıdaki ikinci beyitte dikkat çekilmiş ve metinde şeklinde yazılmış olan fiili ırışmışuz okumuş ve sözlükte fiile "ırış- 2. Birbirinden ayrılmak, uzaklaşmak" (Dilçin, 1991, s. 612b) şeklinde anlam vermiştir. A. Cin, fiili aynı şekilde okumuş (Cin, 2012, s. 344-12) ve sözlükte "yorulmak, bunalmak" (Cin, 2012, s. 558b) olarak anlam vermiştir. Ancak bu okuma şekilleri ve anlamlar bağlama uymuyor.

Burada bağlamı anlamak için bir özet yapmak gerekiyor: Söz konusu yukarıdaki beytin geçtiği bölümde Süheyl'in babasına yazdığı mektuptan söz edilmekte ve mektubun içeriği hakkında bilgi verilmektedir. Süheyl, mektubunun bundan önceki bölümünde Nevbâhar'ı bulduğunu fakat sonradan onu kaybettiğini ve başından geçenleri özetleyerek anlatmıştır. Yukarıdaki iki beyitte ise Nevbâhar ile kavuştuklarını ve Tufan şehrinde hükümdar olduklarını anlatmıştır. Bu beyitte bir kavuşmadan söz edilmiş olduğuna göre fiilin èriş- okunması ve 'kavuşmak' olarak anlaşılması gerekir. Beyitler, yukarıdaki şekilde anlaşılabilir.

5253 ile-ye $\rightarrow$ eyle-ye

\begin{tabular}{|l|l|}
\hline İli güni hāli bulup dileye & İli günü boş görüp isteyecek. \\
Ki ayruh kişi yurdumuz illeye (5253) & Başkası yurdumuzu yurt edecek. \\
\hline
\end{tabular}

C. Dilçin yukarıdaki ikinci dizenin sonunda geçen ve $\mathrm{M}$ nüshasında

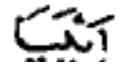
şeklinde yazılmış olan kelimeyi ileye şeklinde okumuş ve sözlükte "yurt edinmek" (Dilçin, 1991, s. 613b) anlamını vermiştir. A. Cin de kelimeyi aynı şekilde okumuş, sözlükte “iley huzur, kat, yan" (Cin, 2012, s. 348-13, 567) şeklinde anlam vermiştir. Dilçin'in verdiği anlam doğrudur ancak söz konusu okuma şekilleri ve A. Cin'in verdiği anlam bağlama uymuyor.

Kanaatimce metnin bu kısmında bir yazım yanlışlığı söz konusudur. Metinde kelimenin illeye okunacak şekilde yazılmış olması gerekirdi. Buna göre beyit yukarıda gösterildiği şekilde anlaşılabilir.

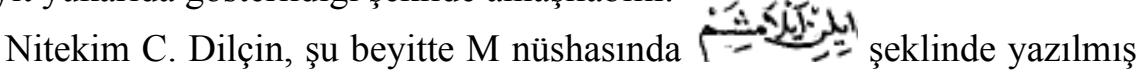
olan fiilin D nüshasında illemişem okunacak şekilde yazılmış olduğunu dip notta belirtmiş ve illemişem şeklinde okumuş ve sözlükte "ille- yurt edinmek" şeklinde işlemiştir: 


\section{Delimden ki Çin ilin illemişem \\ Dişüm yavuz işlere bilemişem (4916) \\ Çoktandır Çin ilini yurt etmişim. \\ Çok kötü işlere diş bilemişim.}

Nitekim söz konusu ille- fiili, Kül Tigin ve Bilge Kağan Yazıtları'nda geçen aynı cümlede de aynı anlamda kullanılmıştır:

"Türük bodun illedük ilin ıçgııu ıdmış" = Türk milleti ülke edindiği toprakları elden çıkarmış. (KTD: 6, BKD: 7)

5294 diril- $\rightarrow$ dèril-

Ben ölmiş iken yine dirilmişem

Tag̉ılmış iken uşda dèrilmişem (5294)
Ben ölmüş iken bak yine dirildim.

Ben dağılmış iken işte derildim.

C. Dilçin, yukarıdaki iki dizenin sonunda geçen iki fiili de dirilmişem (Dilçin, 1991, s. 5294) şeklinde okumuştur. A. Cin ise iki fiili de dèrilmişem (Cin, 2012, s. 351-9) şeklinde okumuştur. Bu okuma şekilleri beyitte anlam vermiyor.

Kanaatimce doğru okuma şekli, birinci dizenin sonundaki fiili dirilmişem, ikinci dizenin sonunda fiili ise dèrilmişem şeklinde olmalıdır. Çünkü beyitte konuşan kişi, Yemen hükümdarıdır. Hükümdar, yıllardır yolunu gözlediği oğlu Süheyl'in dönüşüne sevinmiş ve hissettiği sevinci ifade etmektedir. $\mathrm{Bu}$ beyitte anlam tezat sanatı üzerine kurulmuştur. Söz konusu beyitteki birinci dizede öl- $><$ diril-, ikinci dizede ise ta $\dot{\mathbf{g}}_{1} 1-><$ dèril- tezadı üzerine iki cümle kurulmuş olduğu anlaşılıyor. Buna göre beyit yukarıda gösterildiği şekilde anlaşılabilir.

5421 adın- $\rightarrow$ kadem adın-: adım atmak

\begin{tabular}{|c|c|}
\hline $\begin{array}{l}\text { Anı siz dahı şāh ėdinür misiz } \\
\text { Kadem işbu yola adınur mısız (5421) }\end{array}$ & $\begin{array}{l}\text { Onu siz de şah edinir misiniz? } \\
\text { Bu yola adım atınır mısınız? }\end{array}$ \\
\hline
\end{tabular}

C. Dilçin, yukarıdaki beytin ikinci dizesinde geçen $a d ı n$ - fiili için tereddüt belirterek "Adımını atmak, kendi gitmek (?)" (Dilçin, 1991, s. 583b) şeklinde anlam vermiştir. A. Cin ise fiili, sözlükte "adın-: adım atmak" (Cin, 2012, s. 423b) şeklinde işlemiştir.

Kanaatimce buradaki fiilin "kadem ad(ln)-: adım atmak" şeklinde anlaşılması gerekir. Bu düşüncemin gerekçeleri için bir özet yapmak gerekiyor: Nevbahâr, Cuhud'un gemisinden kaçar ve yolda Tufan şehrinin halkı ile karşılaşır. Tufan halkı Peçeli dolaşan Nevbahâr'ın bir kadın olduğunu anlamaz ve onu şah yaparlar. Bu bağlam, Nevbahâr'ın peçeli olmasından istifade ederek erkek sesini taklit ettiği ve şehri yöneterek kendini şehir halkına kabul ettirdiği anlaşılıyor. Nevbahâr, işinde çok mahir bir nakkaş (mozaik ustası) bulur, ona gizlice yüzünü gösterir ve nakkaşa şehrin dört kapısında kendi resmini yapmasını emreder. Nevbahâr'ın mozaik resmi, inşa edilen giriş kapısının 
kubbesine ve bu kubbenin altındaki havuzdaki su içinde yansıyacak şekilde yapılır. Nevbahâr'ın amacı hem kendisini aramak için şehre gelecek olan aşıklarını yakalatıp onlara ders vermek hem de Süheyl'i bulup ona kavuşmaktır. Nitekim Nevbahâr kurduğu bu planla amacına ulaşır. Dört aşık da şehir girişindeki bu resmi görür ve yakayı ele verir. Bunun üzerine Nevbahâr, şahlık yaptığı şehir halkını toplar, yakalattığı aşıklarına halkın huzurunda Tufan'a neden geldiklerini ve başlarından geçen hikâyelerin ne olduğunu sorup anlattırır. Nevbahâr daha sonra olup biteni dinleyen halka dönerek sözü edilen kız hakkında ne düşündüklerini sorar. Bütün halk kızın cesaretini, iffetini korumasını ve aşkına sadık kalmasını takdir eder. Bunun üzerine Nevbahâr peçesini açar ve anlatılan kızın kendisi olduğunu söyleyerek kimliğini açıklar. Bu açıklamasının ardından Süheyl'i yerine şah etmek istediğini söyler ve halka bu konudaki fikirlerini yukarıdaki -ikinci dizeyle- sorar. Halkın onayını alan Nevbahâr, tacı ve tahtı Süheyl'e teslim eder. Bağlama göre beyit, yukarıda gösterildiği şekilde anlaşılabilir.

Fiilin kadem at- yerine kadem adın- şeklinde kullanılmış olmasının nedeni ise hem ilk dizedeki şāh èdin- ile kafiye oluşturmak hem de vezni sağlamak için yapılmış bir tasarruftur.

5433 1. sen ü ben $\rightarrow$ seni ben

2. esen og̉ur eyle-: vedalaşmak

Sen ü ben esen ugur eyleyeyim

Koçayım boyununı yiyleyeyim (5433)

Yukarıdaki okuma şekli C. Dilçin'e aittir. A. Cin de yukarıdaki ilk dizenin başında geçen kelimeleri metindeki yazılışına uygun olarak sen $\ddot{u}$ ben şeklinde okumuştur. Ancak bu okuma şekli bağlama uymuyor. Kanaatimce metnin bu kısmı, seni ben okunacak şekilde yazılmış olmalıydı.

2. esen og̉ur eyle-: vedalaşmak

C. Dilçin, yukarıdaki beyitte geçen esen og̉ur eyle- deyimini esen ug்ur eyle- şeklinde okumuş ve "birbirine esenlik dilemek" (Dilçin, 1991, s. 606a) şeklinde anlamıştır. A. Cin ise deyimdeki kelimeleri birbirinden bağımsız olarak farklı yerlerde işlemiş̧ir. Kanaatimce deyim, yukarıdaki beyitte 'vedalaşmak' anlamında kullanılmış olmalıdır. Çünkü beyitte ölüm döşeğinde olan Süheyl'in babası, oğluna kendisiyle vedalaşmak istediğini söylemektedir.

\begin{tabular}{|l|l|}
\hline $\begin{array}{l}\text { Seni ben esen oġur eyleyeyim } \\
\text { Kuçayım boyununı yiyleyeyim (5433) }\end{array}$ & $\begin{array}{l}\text { Bugün ben seninle vedalaşayım. } \\
\text { Kucaklayıp boynunu koklayayım. }\end{array}$ \\
\hline
\end{tabular}

Söz konusu esen og̉ur eyle- 'vedalaşmak' deyimi, şu beyitte esen og்uz eyle- okunacak şekilde yazılmıştır: 


\begin{tabular}{|l|l|}
\hline Bunı dėdi eyledi esen oġuz & Esenlik dileyip hem vedalaştı. \\
Ata bindi düşdi yola yalunuz (4054) & Yapayalnız ata bindi, yol aştı. \\
\hline
\end{tabular}

C. Dilçin, bu beyitte deyimi yazılışına uygun olarak esen og $u z$ eyle- okumuş ve deyiminin anlamını "Săg salim, hoşça kalın demek" (Dilçin, 1991, s. 606a) şeklinde vermiştir. A. Cin, ise deyimi "esen ug்uz eyle-" şeklinde okumuş ve "Sağlık, esenlik dilemek" (Cin, 2012, s. 513a)

Deyim, yukarıdaki beyitte kafiye tasarrufu nedeniyle esen og $u z$ eyle- şeklinde kullanılmıştır. Yani bu beyitte Mesud, ikinci dizenin sonunda geçen yalu¡uz kelimesi ile kafiye oluşturmak için esen og ur eyle- deyiminin ikinci kelimesinde kafiye kurmak amacıyla bir tasarrufta bulunmuştur: og $u r>o \dot{g} u z .^{6}$

5440 düş- $\rightarrow$ ter duş-: uygun olmak

Dilersen ki her bir sözün düşe ter

Bişür aş bigi öydin andan kotar (5440)

Araştırmacılar, yukarıdaki ilk dizede dikkat çekilmiş olan fiili düşe 'düşmek' şeklinde okuyup anlamıştır (Dilçin, 1991, s. 3784; Cin, 2012, s. 360-14, 504a). Ancak bu okuma şekli ve anlam bağlama uymuyor. Mesud, beyitte konuşma ve sözün uygunluğu üzerine bir tavsiyede bulunmaktadır. Beyitteki söz konusu fiilin ter duşd1 ( $<$ ter $d u s ̧-d l)$ okunup 'uygun olsun, yerinde olsun' şeklinde anlaşılabilir. Bağlama göre beyti şöyle okuyup anlamak mümkündür:

\begin{tabular}{|l|l|}
\hline Dilersey ki her bir sözüy duşa ter & İster isen her sözün uygun düşe. \\
Bişür aş bigi öydin andan kotar (5440) & Sözü pişir, kaba koy değsin işe. \\
\hline
\end{tabular}

Benzer düzeltmeler için bk. 1517, 2818, 3748, 3611 notları.

5448 erụ̈ assis1 $\rightarrow$ erụ̈ [öz] 1ss1s1

Erǜ assısı çok çok olıcak

Uz olmaz arada kılıç u bıçak (5448)

C. Dilçin, bu beyti yukarıdaki şekilde okumuş ve beyitteki assı kelimesi için "fayda, yarar, çıkar" (Dilçin, 1991, s. 5448, 587a) anlamını vermiştir. A. Cin de aynı okuma şeklini benimsemiş ve assı kelimesi için "fayda, çıkar" (Cin, 2012, s. 438b) anlamını vermiştir. Ancak bu okuma şekli ve anlamlar bağlama uymuyor.

Dilçin, dipnotta D nüshasında beytin başında erụ̈ yerine özụ̈ bulunduğunu belirtmiştir. Kanaatimce bu bilgiden hareketle söz konusu beytin baş kısmı erüy [öz] 1ssıs1 şeklinde tamir edilebilir. Bu okuma şekline göre bir önceki beyitle bu beyit arasında anlam bakımından şöyle bir bütünlük sağlanmış oluyor:

6 Kafiye tasarrufu ve başka örnekler için bk. Özçelik, 2017b. 
Süci içme içer isen içgil az İşidici ol çünki çalına sāz (5447) Erün [öz] ıssısı çok çok olıcak Uz olmaz arada kılıç u biçak (5448)
Şarap içme, içersen de iç biraz. Dinleyen kişi ol, çalınırsa saz. Yiğidin harareti artsa çok az, Arada kılıç, bıçak uygun olmaz.

Nitekim Süheyl ü Nevbahâr'1n şu beytinde öz 1Ss1S1 tamlamasına benzer yapıda öz göynügi geçer: ${ }^{7}$

\begin{tabular}{|l|l|}
\hline Hemin Hāsıl öz göynügi durur renc & Müflisin düşte hazine görmesi \\
Ki müflis kişi bula düşinde genc (2924) & Yalnızca sıkıntı, yürek yanması \\
\hline
\end{tabular}

$\mathrm{Bu}$ tamire göre beyitler yukarıda gösterildiği şekilde anlaşılabilir.

5461 dèril-: toplan!; diril!: yaşa, hayat sür!

\begin{tabular}{|l|l|}
\hline Yabāna tag்ılma evüne dèril & Dişarda dolanma evine deril! \\
Bu halk arasında sen eyle diril (5461) & Sen bu halk içinde öylece diril! \\
\hline
\end{tabular}

C. Dilçin, yukarıdaki beyitin ilk dizesinde dikkat çekilen fiili, diril şeklinde okumuş ve sözlükte "toplanmak" (Dilçin, 1991, s. 601a) anlamını vermiştir. A. Cin ise iki dizenin sonunda da fiilleri derril-okumuş ve anlamı "toplanmak, bir araya gelmek; yaşamak; geçinmek" (Cin, 2012, s. 492b) şeklinde vermiştir.

Söz konusu fiiller birinci dizenin sonundaki dèril! 'toplan!', ikinci dizenin sonunda ise diril! 'yaşa, hayat sür!' şeklinde ve anlamında kullanılmıştır.

\section{2}

\section{Kişi katına olmasun giresin}

\section{Unıtmaġ1l ölüp sine giresin (5482)}

Yukarıdaki beyitte bir anlaşılma sorunu bulunduğunu düşünüyorum (bk. Cin, 2012, s. 363-11, 530b). Oysaki söz konusu beyitte bir cinas yakalanmıştır. Bu beyitteki ilk dizede giresi ol- 'girmek istemek' deyimi ikinci kişi çekimi (<gir-esi+n ol-ma-sun) 'girmek isteme(yesin)' anlamında kullanılmıştır. İkinci dizenin sonunda geçen sine giresin ise 'mezara gireceksin' anlaminda kullanılmıştır. Buna göre beyiti Türkiye Türkçesine şu şekilde aktarmak mümkündür:

\begin{tabular}{|l|l|}
\hline Kişi katına olmasun giresin & Kul yanına hiç olmasın giresin. \\
Unıtmağıl ölüp sine giresin (5482) & Unutma ölüp kabre sen giresin. \\
\hline
\end{tabular}

\section{3 aşa (<aşag̉a)}

Saçın yoldı vü urdı başın taşa

Saçar idi toprak başından aşa (5503)
Saçın yoldu, başın taşlara vurdu.

Hem başına toprak döküp savurdu.

7 Beyitle ilgili düzeltme için bk. 2924 notu. 
Araştırmacılardan C. Dilçin, yukarıdaki ikinci dizeninin sonunda geçen aşa kelimesini sözlükte işlememiştir (Dilçin, 1991). A. Cin ise bunu aş- fiil başlığı altında işlemiştir. Ancak buradaki aşa kelimesinin de aş- fiil kökü ile ilgisi yoktur. Ayrıca aş- fiili zaten bağlama uymaz.

Söz konusu aşa kelimesi, son hecesi eksiltilerek kullanılmış olan aşaġa 'aşağı' kelimesinden başka bir şey değildir. Mesud, hem ilk dizenin sonunda geçen taşa kelimesiyle kafiye kurmak hem de vezni sağlamak bakımından kelimenin son hecesini düşürmüş ve böyle bir tasarrufta bulunmuştur. Nitekim kelimenin 2, 1656, 3473, 4487. beyitlerde geçen diğer örnekleri aşag்a şeklindedir.

5598 yarusı $\rightarrow$ Pārüsî

'Arabca bulınmayıcak Pārüsî

Kalan dilleründür bayık arusı (5598)

Eğer Arapça olmaz ise Farsça.

Diğer dillerden de daha güzelce.

Yukarıdaki birinci dizenin sonunda dikkat çekilmiş olan kelime $\mathrm{M}$ nüshasında menin Pārsî okunacak şekilde yazılmış olduğunu belirtmiştir. Araştırmacılar kelimeyi M nüshasındaki yazılışına uygun olarak yarusı şeklinde okumayı tercih etmiştir (Dilçin, 1991, s. 5598; Cin, 2012, s. 371-17). Ancak bu okuma şekli ve anlam beyitte uygun düşmüyor.

Kanaatimce ikinci dizenin başındaki kalan kelimesini anlamak beyti anlamayı kolaylaştıracak noktadır. İkinci dizenin başındaki kalan kelimesi, 'diğer' anlamında kullanılmıştır. Bağlamı dikkate aldığımızda tartışmalı kelimenin Pārüsî 'Farsça' olduğu açıkça anlaşılmaktadır. Söz konusu beyit ise yukarda gösterildiği şekilde anlaşılabilir.

5599-5600 ili (<ala), ili: ala, alaca, karışık

\begin{tabular}{l|l}
\hline 'Arabca bulınmayıcak Pārüsi & Arapça olmasa eğer şu Farsça. \\
Kalan dilleründür bayık arusı & Öteki dillerden hep daha hoşça \\
Bu iki dile baksa Türküy dili & Türkün dili baksan bu iki dile. \\
Çah oldur ki sāfi katında ili & Halkların yanında yalnızca ala. \\
Başarsa kişi hem degüldür güzaf & Kişi başarsa bu söz değildir boş. \\
Ki ilinüy içinden ol süze sāf(5598-5600) & Bir ala içinden saf süzülse hoş. \\
\hline
\end{tabular}

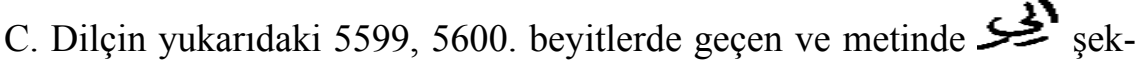
linde yazılmış olan kelimeyi yazılışına uygun olarak ili okumuş, sözlükte "saf olmayan, karışık, katışık (?)" (Dilçin, 1991, s. 614) anlamlarını vermiş ve tereddüt belirtmiştir. Dilçin' in kelimenin anlamı konusunda tereddüt belirtmesi muhtemelen sözlüklerde ili kelimesini bulamamış olması ve kelimenin neden bu şekilde yazılmış olduğunu yorumlayamamış olması ile ilgilidir. A. Cin de 
aynı okuma tercihini benimsemiş ancak sözlükte kelimeyi işlememiştir (Cin, 2012, s. 371-8, 371-9).

S. Tezcan ise yazdığı notta söz konusu kelimeyle ilgili olarak "Anadolu ve Azerbaycan Türkçesindeki lil kelimesinin yanbiçimi olabilir mi?" sorusunu sormuş ve Steingass 1134'e dayanarak Farsça $l i$ 'kil' ile karşılaştırılmasını istemiştir (Tezcan, 1994, s. 66). Tezcan, daha sonra yazdığı bir makalede ise Dankoff' un kendisine yazmış olduğu bir mektupta söz konusu kelimeyi 11 1 okuyup '1lık' anlamında yorumladığını fakat burada "durmuş, kokuşmuş su”" olarak yorumladığını ve haklı olabileceğini yazmıştır (Tezcan, 1995, s. 244).

Kanaatimce burada kelimenin Ş şeklinde yazılmış olması, kelimede yapılmış olan kafiye tasarrufu konusuyla ilgili bir durumdur. Bu nedenle kelime, yazılışına uygun olarak ili şeklinde okunmalıdır. Mesud, aslında ala 'ala, karışı' olan bu kelimede ilk dizenin sonundaki Türkü̈ dili tamlaması ile kafiye kurmak için bir kafiye tasarrufunda bulunarak ala kelimesinin ünlülerini değiştirmiştir $(a l a>i l i) /(a>i)$. Yani burada Mesud'un ili şeklinde kulland1ğ kelime, ala'dan başka bir şey değildir. Kelime yukarıdaki beyitlerde mecaz yollu 'karışı, muğlak' anlamında kullanılmıştır. Buna göre de Dilçin'in -muhtemelen metindeki bağlama dayanarak- vermiş olduğu anlam doğrudur. Mesud'un kafiye endişesiyle tasarrufta bulunarak ili'ye çevirdiği bu kelimeyi hemen sonraki 5600. beyitte de kullanmış olması, araştırmacıları yanıltmıştır. Söz konusu beyit yukarıda gösterildiği şekilde anlaşılabilir.

5662 gözlemek $\rightarrow$ közlemek: 'közlenmek, yanmak'

\begin{tabular}{|l|l|}
\hline $\begin{array}{l}\text { İşüm çoh belā tartmah u gizlemek } \\
\text { Degül eksügüm artmah u közlemek } \\
(5662)\end{array}$ & $\begin{array}{l}\text { İşim çok sıkıntı çekip gizlemek. } \\
\text { Değil eksiğim artırıp közle(n)mek. }\end{array}$ \\
\hline
\end{tabular}

C. Dilçin, yukarıdaki beytin ikinci dizesinin sonundaki fiili gözlemek okumuştur. C. Dilçin'in hazırlamış olduğu sözlükten bu kelimeyi nasıl anladığ anlaşılmıyor. A. Cin de fiili aynı şekilde okumuş (Cin, 2012, s. 375-11) ve sözlükte kelime için "gözetmek" (Cin, 2012, s. 540b) anlamını vermiştir.

Söz konusu fiil, birinci dizenin sonundaki gizlemek ile kafiyeli olarak közlemek şeklinde fakat közlenmek 'yanmak' yerine kullanılmıştır. Yani Mesud, fiili bu şekilde kullanarak bir kafiye tasarrufunda bulunmuştur. Bu nedenle fiil, yazılışına uygun olarak közlemek okunmalı ve 'közlenmek, yanmak' olarak anlaşılmalıdır. Beytin yukarıda gösterildiği şekilde anlaşılması uygundur. 


\section{Kisaltmalar \\ D nüshası: Süheyl ü Nevbahâr, Dehri Dilçin nüshas1. \\ M nüshası: Süheyl ü Nevbahâr, Mordtmann nüshası. \\ TarS: Tarama Sözlüğ̈̈, Türk Dil Kurumu yayınları.}

\section{Kaynaklar}

Aktunç, H. (2000). Türkçenin Büyük Argo Sözlüğü (Tanıklarlyla). İstanbul: Yap1 Kredi.

Altaylı, S. (1994). Azerbaycan Türkçesi Sözlüğü I-II. İstanbul: Millî Eğitim Bakanlığı.

Arat, R. R. (1992). Atebetül-Hakâylk. Ankara: Türk Dil Kurumu.

Atalay, B. (1986). Divanü Lûgat-It-Türk Tercümesi (4 Cilt). Ankara: Türk Dil Kurumu.

Banguoğlu, T. (1938). Altosmaische Sprachstudien zu Süheyl ü Nevbahâr. Breslau.

Cin, A. (2012). Mesud bin Ahmed Süheyl ü Nev-Bahâr (Kenzü'l-Bedâŷ̀ '); Inceleme-MetinDizin. Konya: Eğitim.

Çelebioğlu, Â. (1976). Sultan II. Murad Devri Mesnevileri. (Doçentlik tezi). Atatürk Üniversitesi İslami İlimler Fakültesi, Erzurum. s. 35-39.

Dilçin, C. (1991). Mes'ūd bin Ahmed Süheyl ü Nev-Bahâr; Inceleme-Metin-Sözlük. Ankara: Atatürk Kültür Merkezi.

Dilçin, C. (1995). Örneklerle Türk Şiir Bilgisi. Ankara: Türk Dil Kurumu.

Ercilasun, A. B. (2008). "La Enklitiği ve Türkçede Bir 'Pekiştirme Enklitiği' Teorisi”. Dil Araştırmaları, 2, 35-56.

Karataş, T. (2004). Ansiklopedik Edebiyat Terimleri Sözlüğü. Ankara: Akçă̆.

Köprülü, M. F.(1928). Millî Edebiyat Cereyanının İlk Mübeşşirleri, İstanbul.

Ma'luf, L. (1973). El-Müncid Fi’l-Luga. Beyrut.

Mütercim Asım Efendi (2000). Burhân-ı Katı. M. Öztürk, D. Örs (haz.). Ankara: Türk Dil Kurumu.

Mütercim Asım Efendi (2014). Kâmûs'l-Muhît Tercümesi. M. Koç, E. Tanrıverdi (haz.). İstanbul: Türkiye Yazma Eserler Kurumu.

Mordtmann, J .H. (1925). Suheil und Nevbehâr. Hannover.

Özçelik, S. (2012). "Süheyl ü Nevbahâr Üzerine Düzeltmeler”. Uluslararası VIII. Klâsik Türk Edebiyatı Sempozyumu (15-17 Kasım 2012).

Özçelik, S. (2014). “Süheyl ü Nevbahâr Üzerine Düzeltmeler”. Uluslararası Türkçe Edebiyat Kültür Eğitim Dergisi (TEKE), 3/2, 62-79.

Özçelik, S. (2016/I). Dede Korkut-Dresden Nüshast- Giriş, Notlar I. Ankara: Türk Dil Kurumu.

Özçelik, S. (2016/II). Dede Korkut -Dresden Nüshast- Metin, Dizin II. Ankara: Türk Dil Kurumu.

Özçelik, S. (2016). "Tarihî Metin Okumalarında Kelimeyi Bölme ve Kelimeleri Birleştirme Sorunları: Süheyl ü Nevbahâr'dan Örnekler”. Uluslararası Türkçe Edebiyat Kültür Eğitim Dergisi (TEKE), 5/4, 1593-1602.

Özçelik, S. (2017a). "Tarihî Metinlerde Yuvarlak Ünlülerin Okunması Sorunu: Süheyl ü Nevbahâr'dan Örnekler”. Uluslararası 8. Türk Dil Kurultayı. 
Özçelik, S. (2017b). “Süheyl ü Nevbahâr'da Kafiye Tasarrufları”. Divan Edebiyatı Araştırmalart Dergisi, 18, 425-440.

Özçelik, S. (2017c). "Süheyl ü Nevbahâr ve Tarama Sözlüğü’nde boyla- Fiili Üzerine Düzeltmeler”. Uluslararası Türkçe Edebiyat Kültür Eğitim Dergisi (TEKE), 6/4, 21142121.

Özçelik, S. (2017ç). “Süheyl ü Nevbahâr Üzerine Düzeltmeler (2)”. Türk Dili Araştırmalarl Yillı̆̆ Belleten, 65/2, 233-242.

Pala, İ. (2004). Ansiklopedik Divan Şiiri Sözlüğü. İstanbul: Kap1.

Saraç, Y. (2012). Klâsik Edebiyat Bilgisi - Biçim-Ölçü-Kafiye. İstanbul: Gökkubbe.

Steingass, F. (1892). A Comprehensive Persian-English Dictionary. London.

Tarama Sözlüğ̈̈ (1977). Ankara: Türk Dil Kurumu.

Taş, İ. (2009). Süheyl ü Nevbahâr'da Eskicil Öğeler. Konya: Palet.

Taş, İ. (2015). Süheyl ü Nevbahārda Eskicil Ögeler. Ankara: Türk Dil Kurumu.

Tezcan, S. (1994). Süheyl ü Nev-bahâr Üzerine Notlar. Ankara: Simurg.

Tezcan, S. (1995a). “Mes'ud ve XIV. Yüzyıl Türk Edebiyatı Üzerine Yeni Bilgiler”. Türk Dilleri Araştırmaları, 5, 65-84, Ankara: Simurg.

Tezcan, S. (1995b). "Süheyl ü Nev-bahâr Üzerine Notlara Birkaç Ekleme". Türk Dilleri Araştırmaları, 5, 239-245, Ankara: Simurg.

Yavuz, K. (1991). Şeyhoğlu Kenzü'l-Küberâ ve Mehekkü'l-Ulemâ (Inceleme-Metin-İndeks). Ankara: Atatürk Kültür Merkezi. 


\section{ABSTRACT}

We have very limited knowledge about the period of Old Anatolian Turkish. In addition, works on works written in Old Anatolian Turkish period are limited. However, it is understood that Turkish language and literature started to develop in Anatolia during this period and Turkish translation and copyright works were put forward. Again in this period, it can be said that mesnevies occupy an important place within the mentioned works. In this period, it is seen that small mesnevies with religious theme were written or translated. The reason for writing such mesnevis is the idea of spreading the teachings of religion and mysticism to the wider public. In this period of social and political turmoil, it has been seen that it is important to nurture the feelings of religious and heroic feelings in the society. As a result of this thought, it is understood that epic mesnevies were written on religion. However, it is necessary to say that long mesnevies were written in the same period. One of the longest mesnevies written in Old Anatolian Turkish is Süheyl ü Nevbahar. This work, which is about six thousand couplets, is known as the mesnevi on the subject of the first human love written in this period.

Mesut Bin Ahmad's Suhayl ü Nev-bahâr named mesnevi is one of the most important texts of Old Anatolian Turkish especially in terms of vocabulary.

Cem Dilçin published this important mesnevi in a study consisting of text, review and a limited dictionary (Dilçin, 1991). In this book, Dilçin has prepared an introductory chapter, which provides important insights and observations on mesnevi text and content. Afterwards, we see that the text on this text is complementary studies in terms of reading and vocabulary. Semih Tezcan, Dilçin's study of the unread, wrongly read or misinterpreted the words of the correction notes as a small booklet before (Tezcan, 1994). Tezcan later published a small paper as a continuation of it (Tezcan, 1995). İbrahim Taş published his notes on the vocabulary of Süheyl ü Nev-bahâr mesnevi in a small booklet called Süheyl ü Nevbahâr notda Eskicil Öğeler (Taş, 2009).

Some shortcomings or misreadings may be seen during the reading of historical texts. Correct reading of these false readings is usually left to other researchers. Each new study may include views that will illuminate the text, and may be an obstacle to correct reading. So sometimes a new unrequited proposal about reading may mislead subsequent researchers. Because, in historical text, there can always be many language elements that are not used in today's language, which are not used and which are dark to us. For this reason, it is important to read the writings on historical texts by carefully and diligently relating the texts to the text in question. At this point, the work of the researcher is very complex and requires patience. On the one hand, pay attention to the 
binding, on the other hand it is necessary to sort the notes about the text and not skip. An opposite attitude or jumping may make the researcher mislead.

One of the important points of attention in the reading of historical texts is understanding and reading. Based on our experience and knowledge, we can easily navigate between words and phrases in text reading. But between the lines of the historical text, we may be faced with structures that we do not know or understand at every step and step.After the first reading, we may notice that we did not understand the parts of the text that we read incorrectly, thanks to the new readings we made to read and understand the texts means to understand both words and culture correctly.It is also important in terms of enlightening the etymology of the words to read by understanding historical texts.

Every historical text, of course, has versatile reading difficulties. Because of these difficulties in reading, some problems of reading can be seen in studies on historical texts. The most important reason for the reading problems is the text reading the meaning. On the other hand, reading, understanding and evaluating the text is a serious scientific work, above all. Because the reading of historical texts contributes both to my past and present. Of course, in order for the comments to be developed through these readings to be realistic and horizon-first, it is essential that the reading itself is correct. It is clear that science cannot be made on false information in any other way.

As new reading studies on Süheyl ü Nevbahar progressed, we wrote corrections proposals about the problems of reading. It has been shown in the sources of related papers and articles. As we got closer to the end of the work, we found corrections for new reading problems. This article presents new reading proposals as a continuation of previous reading proposals.

In the article Süheyl ü Nevbahar focuses on the problems that have arisen in the reading, comprehension and reading of unified structures. Evidence is also presented by offering examples from Süheyl ü Nevbahar or other works. 